\title{
Dietary factors and K-ras oncogene mutations in sporadic colorectal cancer
}

Citation for published version (APA):

Brink, M. (2004). Dietary factors and K-ras oncogene mutations in sporadic colorectal cancer. [Doctoral Thesis, Maastricht University]. Universiteit Maastricht. https://doi.org/10.26481/dis.20041119mb

Document status and date:

Published: 01/01/2004

DOI:

$10.26481 /$ dis. $20041119 \mathrm{mb}$

Document Version:

Publisher's PDF, also known as Version of record

\section{Please check the document version of this publication:}

- A submitted manuscript is the version of the article upon submission and before peer-review. There can be important differences between the submitted version and the official published version of record.

People interested in the research are advised to contact the author for the final version of the publication, or visit the DOI to the publisher's website.

- The final author version and the galley proof are versions of the publication after peer review.

- The final published version features the final layout of the paper including the volume, issue and page numbers.

Link to publication

\footnotetext{
General rights rights.

- You may freely distribute the URL identifying the publication in the public portal. please follow below link for the End User Agreement:

www.umlib.nl/taverne-license

Take down policy

If you believe that this document breaches copyright please contact us at:

repository@maastrichtuniversity.nl

providing details and we will investigate your claim.
}

Copyright and moral rights for the publications made accessible in the public portal are retained by the authors and/or other copyright owners and it is a condition of accessing publications that users recognise and abide by the legal requirements associated with these

- Users may download and print one copy of any publication from the public portal for the purpose of private study or research.

- You may not further distribute the material or use it for any profit-making activity or commercial gain

If the publication is distributed under the terms of Article $25 \mathrm{fa}$ of the Dutch Copyright Act, indicated by the "Taverne" license above, 


\title{
"Dietary factors and $\boldsymbol{K}$-ras oncogene mutations in sporadic colorectal cancer"
}

\author{
M.Brink
}

\section{ISBN}

\section{Cover}

Lay-out Printing
90-6464-099-8

Mieke Veltman-Hoedemaker

Nathalie Slangen,Capaciteitsgroep Epidemiologie, Universiteit Maastricht Grafisch bedrijf Ponsen \& Looijen BV, Wageningen

\section{○ 2004, M. Brink}

All rights reserved. No part of this thesis may be reproduced or transmitted in any form or by any means, electronic or mechanical, including photocopying, recording or any information storage or retrieval system, without permission in writing from the author, or, when appropriate, from the publisher of the publications 


\title{
Dietary factors and $K$-ras oncogene mutations in sporadic colorectal cancer
}

\author{
PROEFSCHRIFT
}

ter verkrijging van de graad van doctor aan

de Universiteit Maastricht. op gezag van de Rector Magnificus, Prof. mr. G.P.M.F. Mols, volgens het besluit van het College van Decanen, in het openbaar te verdedigen op vrijdag 19 november 2004 om 12.00 uur

door

Mirian Brink

geboren op 3 oktober 1973 te Gieten (Drenthe) 


\section{Promotor}

Prof. dr. ir. P.A. van den Brandt

\section{Co-promotores}

Dr. ir. M.P. Weijenberg

Dr. A.F.P.M. de Goeij

\section{Beoordelingscommissie}

Prof. dr. F.J. van Schooten (voorzitter)

Prof. dr. R-J.M. Brummer

Prof. dr. M.J.A.P. Daemen

Prof. dr. ir. R.P. Mensink

Prof. dr. ir. P. van 't Veer (Wageningen Universiteit)
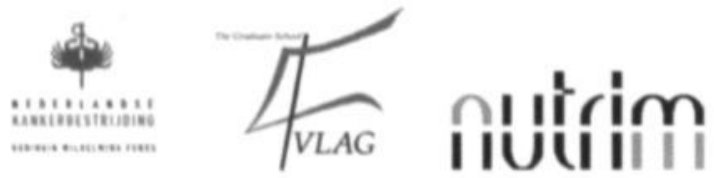

This project was funded by a grant from the Dutch Cancer Society (KWF grant UM 99-1980)

This project was performed at the Department of Epidemiology (Maastricht University). Nutrition and Toxicology Research Institute Maastricht (NUTRIM), which participates in the Graduate School VLAG-2 (Food Technology. Agrobiotechnology. Nutrition and Health Sciences) accredited by the Royal Netherlands Academy of Arts and Sciences, and the Department of Pathology (Maastricht University), Research Institute Growth and Development (GROW).

Financial support for the printing of this thesis was kindly provided by the Department of Epidemiology (Maastricht University) and the Dutch Cancer Society. 


\section{Contents}

1. Introduction

2. K-ras oncogene mutations in sporadic colorectal cancer in The Netherlands Cohort Study

Carcinogenesis, 2003, 24(4), 703-710

3. Meat consumption and $K$-ras mutations in sporadic colon and rectal cancer in The Netherlands Cohort Study

Submitted for publication

4. Fat and $K$-ras mutations in sporadic colon and rectal cancer in The Netherlands Cohort Study

Carcinogenesis, 2004, 25(9), 1609-1628

5. Dietary folate intake and $K$-ras mutations in sporadic colon and rectal cancer in The Netherlands Cohort Study

In press by the International Journal of Cancer

6. General Discussion 
Introduction 


\section{BURDEN OF COLORECTAL CANCER}

Colon and rectal cancer are the fourth most common types of cancer in the world (1). In both men and women, incidence of colon cancer occurs at a similar rate. However, cancer of the rectum has a $20-50 \%$ higher incidence in men than in women. In The Netherlands, colon and rectal cancer rank fourth (world standard annual incidence rate (WSR) 23 per 100,000 persons) and sixth (WSR 15 per 100,000 persons) on the list of most frequent cancers among men and second (WSR 19 per 100,000 persons) and eighth (WSR 9 per 100,000 persons) among women, respectively (Cancer Incidence in Five Continents, vol. VIII, 2002).

High-risk areas include North America, Western Europe, New Zealand and Australia. Central and South America, Asia and Africa are areas of low risk, but the incidence in these areas rises consistently with migration and westernisation of diet (2-4). Migrant and temporal trend studies suggest that colon and rectal cancer are determined largely by environmental exposures, such as diet. The cancer risk rates of migrants who move from low-to-high-risk countries tend to increase to the rates of the host countries within one or two generations, or even as early as within the migrating generation itself. Lichtenstein et al (5) suggested that environmental factors may contribute a proportion of approximately $65 \%$ to the susceptibility to colorectal cancer (CRC).

\section{DIETARY FACTORS AND AETIOLOGY OF SPORADIC COLORECTAL CANCER}

In a multitude of prospective cohort and case-control studies, the importance of dietary factors for CRC incidence has been investigated. The most common hypotheses from epidemiological studies suggest that an increased risk of CRC is the result of a typical western diet, rich in fat and low in fibre $(6,7)$. However, most of the associations between dietary factors and CRC are still prone to debate.

Regarding dietary fat, it has been difficult to determine whether it is the fat content of diet or the associated consumption of meat, which is related to the increased risk of CRC. Epidemiological evidence, supported by identification of biological mechanisms through experimental evidence, suggests that a diet high in total fat and saturated fat possibly increases the risk of CRC (8-10). The evidence with respect to diets high in monounsaturated fat or polyunsaturated fat and the risk of CRC is inconsistent (11-13). Energy intake was suggested to be increased associated with colon cancer risk in some studies, after adjustment for physical activity $(10,14)$. Regarding meat, associations have been found with red meat consumption (15), with the preparation of meat, like high temperature cooking, and with processed meat $(4,9,16)$. Fish consumption is inversely associated with CRC $(12,17)$.

A diet rich in dietary fibre, vegetables and fruit has been suggested to be protective of CRC $(6,18,19)$. For a potential protective effect of dietary calcium on CRC, overall results from case-control and cohort studies indicate no effect (19-21). High intake of both folate and methionine are inversely associated with CRC risk $(22,23)$, whereas deficient intakes of folate or methionine, in combination with high alcohol consumption, may be positively associated with CRC $(24,25)$. For high intake of alcohol, a majority of epidemiological studies have reported either an increased risk of colon cancer $(26,27)$ or of rectal cancer $(28,29)$ or no association at all $(30,31)$.

Although part of the inconsistent findings may be due to methodological issues related to the assessment of dietary intake, study design or chance, these are unlikely to be the only causes. These findings may also result from the oversimplified approach of CRC as a suddenly arising disease entity and which does not account for the different genes involved. 
Therefore, a better aetiological understanding of CRC requires careful molecular analysis of the genetic changes involved in carcinogenesis in relation to exogenous factors.

\section{DEVELOPMENT OF SPORADIC COLORECTAL CANCER}

Approximately $5 \%$ of all CRCs are directly caused by inherited genetic abnormalities. The hereditary forms include familial adenomatous polyposis (FAP) and hereditary nonpolyposis colon cancer (HNPCC). FAP arises because of a mutation in the adenomatous polyposis coli (APC) gene, a tumour suppressor gene, whereas HNPCC results from mutations in DNA mismatch repair genes $(32,33)$. Studies of these hereditary forms of CRC have given us many clues for understanding the molecular basis of sporadic CRC. In this thesis the focus will be on the sporadic, i.e. non-hereditary, form of CRC.

\section{The adenoma-carcinoma sequence}

The adenoma-carcinoma sequence (34), the model for pathogenesis of CRC proposed in 1989, is now widely accepted. According to this model, the initial colorectal lesion arises as a benign adenomatous polyp that later undergoes further disorganisation which leads to

Morphological appaerance

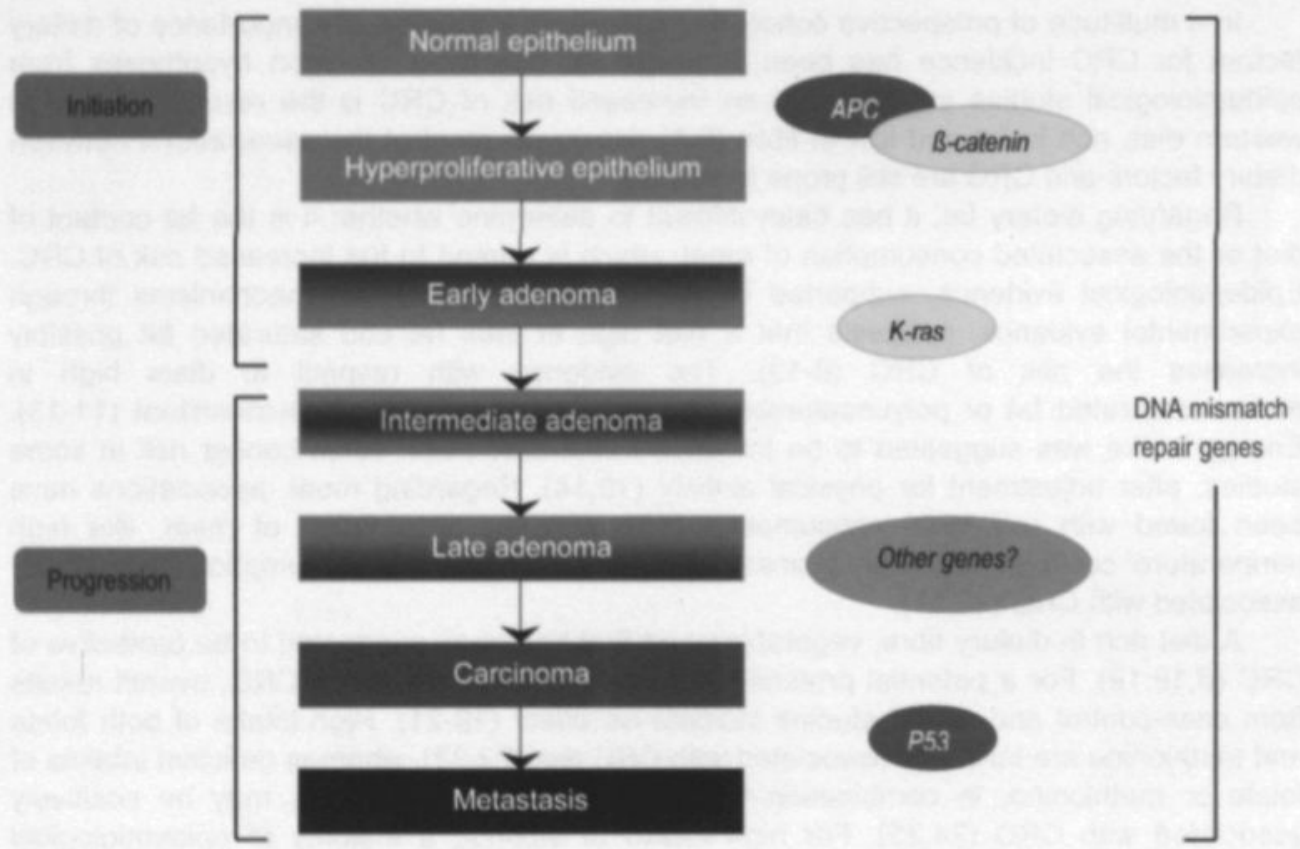

Figure 1 The adenoma-carcinoma sequence and genetic alterations, adapted from Fearon and Vogelstein (35). The tumour suppressor genes APC and P53 are indicated in green, the oncogenes $\mathrm{K}$-ras and $\mathrm{B}$-catenin in yellow and other genes in pink. 
changes in phenotype. Some earlier stages in the process have also been proposed: hyperproliferation of the upper crypt cells, aberrant crypt foci, and microadenomas. Both adenomatous polyps and microadenomas may progress to a malignant carcinoma, and finally metastasis may occur.

\section{A genetic model for the adenoma-carcinoma sequence}

A molecular basis for the adenoma-carcinoma progression has been presented (35) and this model describes the accumulation of alterations in various genes that control cell growth and differentiation, a complex multistep process which results in a neoplastic phenotype (figure 1). This process involves cumulative rather than sequential somatic genetic and epigenetic changes. Some tumour suppressor genes, in particular the APC gene, are known to prevent CRC through direct control of cell growth. Inactivation of these genes contributes directly to the neoplastic growth of the tumour; thus, the normal gene products function as "gatekeepers" and prevent uncontrolled growth $(33,36,37)$. These traditional tumour suppressor genes may be joined by a number of genes responsible for repair of the genome, like human MutL homologue 1 (hMLH1) and human MutH homologue 2 (hMSH2), that indirectly suppress neoplasia. These genes encode DNA repair proteins that act as "caretakers" of the genome $(33,36,37)$. Inactivation of these genes may result in greatly increased mutation rates and can be considered as equivalent to a constant exposure of mutagens $(33,36)$. However, it is not clear whether such defects lead directly to cancer, as restoration of these functions in cancer cells has not been found to affect their growth (36).

One of the first events in the adenoma-carcinoma sequence is presumably an alteration in the APC gene that leads to a functional loss of the APC protein and occurs in $70-80 \%$ of sporadic colorectal adenomas and carcinomas $(35,38)$. Evidence that $A P C$ mutations are involved in the development of an adenoma from normal colonic epithelium, was found in studies performed with FAP patients $(32,33)$. A mutation in the $K$-ras oncogene is another early event in the adenoma-carcinoma sequence. $K$-ras mutations affect the progression from a small to a large adenoma. The gene has been found mutated in $10 \%$ of the screened adenomas smaller than $1 \mathrm{~cm}$, and in $30-60 \%$ of adenomas larger than $1 \mathrm{~cm}$ and in adenocarcinomas $(35,38)$. In addition to mutations in the APC and/or $K$-ras genes, mutations in other oncogenes and tumour suppressor genes may occur, such as in $\beta$-catenin and $p 53$. Some events occur relatively early, including functional loss of the APC gene and mutation of the K-ras oncogene, whereas functional loss of other genes, such as p53, are usually late events $(35,37)$.

\section{The $\boldsymbol{K}$-ras oncogene}

In a significant proportion (30-60\%) of the cancers in colon and rectum, the $K$-ras gene is found to be mutated. The $K$-ras gene product, a $21 \mathrm{kDa}$ protein located at the inner plasma membrane, is activated transiently as a response to extracellular signals such as growth factors, cytokines and hormones that stimulate cell surface receptors. The Ras protein is involved in the transduction of mitogenic signals, and multiple downstream effectors of Ras have been revealed, including Raf-1, phosphatidylinositol-3 kinase, and RalGEF, which are involved in cell growth and proliferation. The hallmark of Ras protein function is the switch between its inactive state, in which the protein is bound to guanosinediphosphate (GDP), and an active state in which conversion to guanosine-triphosphate (GTP) occurs. This transit is governed by two types of regulatory proteins: GDP-GTP exchange factors that catalyse the GDP-GTP exchange and GTPase-activating proteins that enhance the intrinsic capacity of Ras proteins to hydrolyse GTP into GDP, thereby returning the Ras protein into its inactive state. 
Table 1 Overview of case-control and case-case studies of associations between dietary factors and $K$-ras mutation status in colorectal adenomas and carcinomas

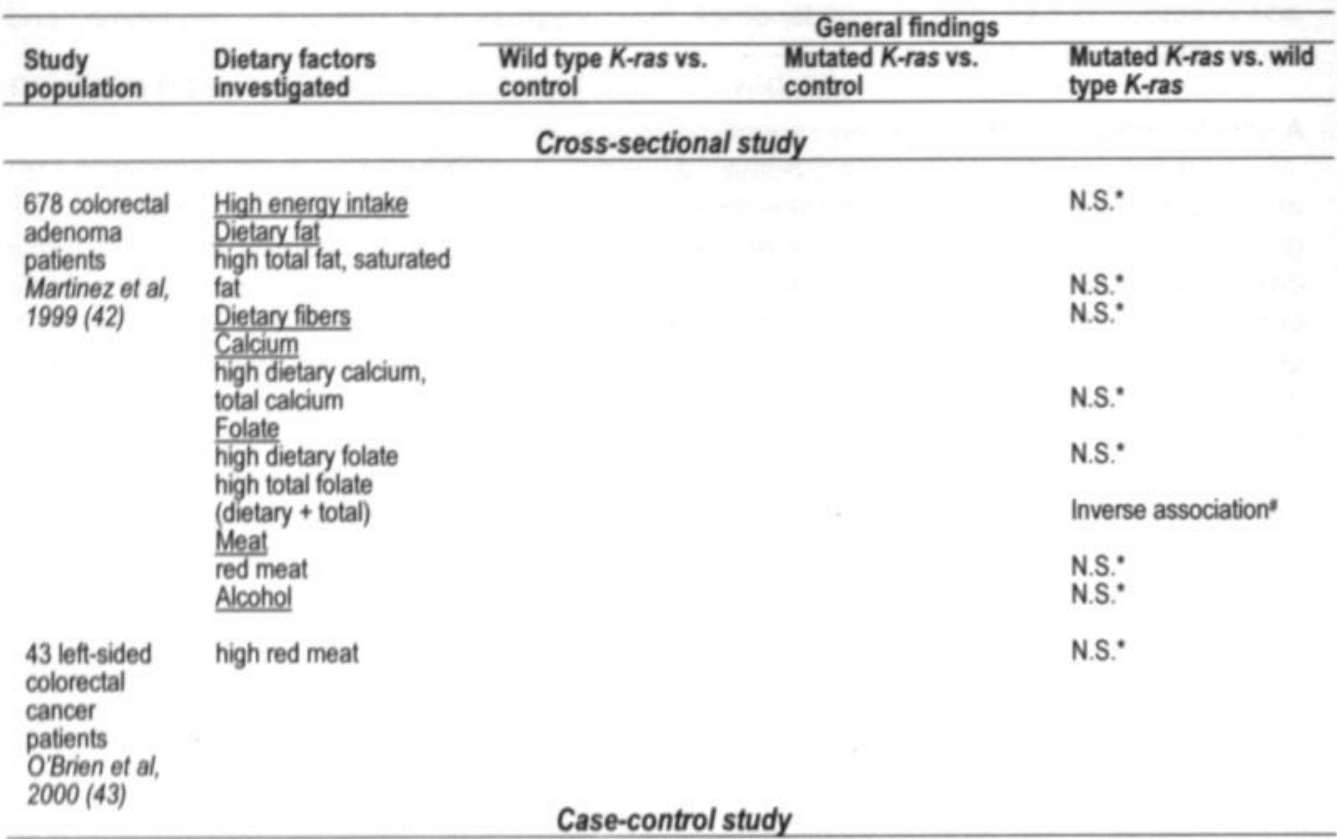

\begin{tabular}{|c|c|c|c|c|}
\hline $\begin{array}{l}108 \text { colorectal } \\
\text { cancer } \\
\text { patients and } \\
295 \text { controls } \\
\text { Bautista et al, } \\
1997 \text { (46) }\end{array}$ & $\begin{array}{l}\text { Energy intake } \\
\text { high calories, proteins } \\
\text { (total, animal or } \\
\text { vegetable) } \\
\text { Dietary fat } \\
\text { high total fats, } \\
\text { polyunsaturated fat, } \\
\text { saturated fat, } \\
\text { cholesterol } \\
\text { High monounsaturated } \\
\text { at } \\
\text { Fibers } \\
\text { high carbohydrates, } \\
\text { fiber (total, vegetable, } \\
\text { cereal, fruit or legume) } \\
\text { Minerals } \\
\text { high phosphorous, } \\
\text { sodium, potassium,iron, } \\
\text { magnesium, zinc } \\
\text { Vitamins } \\
\text { high vitamin } B_{1} \text {, vitamin } \\
\text { B }_{2} \text { vitamin } B_{6} \text {, vitamin } \\
\text { Bi2, niacin, folic acid, }_{\text {vitamin C, vitamin A, }} \\
\text { retinal, carotene, } \\
\text { vitamin E, vitamin D } \\
\text { Calcium }\end{array}$ & Inverse association" & Inverse association" & $\begin{array}{l}\text { N.S." } \\
\text { Increased association" } \\
\text { N.S. } \\
\text { N.S. }\end{array}$ \\
\hline $\begin{array}{l}185 \text { colon } \\
\text { cancer } \\
\text { patients } \\
\text { Kampman et } \\
\text { al, } 2000 \text { (45) }\end{array}$ & $\begin{array}{l}\text { Meat } \\
\text { high total red meat, } \\
\text { processed meat, } \\
\text { poultry, fish } \\
\text { Dairy products, calcium } \\
\text { Dietary fat } \\
\text { total fat, saturated fat, } \\
\text { cholesterol }\end{array}$ & & & $\begin{array}{l}\text { N.S.: } \\
\text { N.S.: } \\
\text { N.S. }\end{array}$ \\
\hline
\end{tabular}


Table 1 continued

\begin{tabular}{|c|c|c|c|c|}
\hline \multirow[b]{2}{*}{$\begin{array}{l}\text { Study } \\
\text { population }\end{array}$} & \multirow[b]{2}{*}{$\begin{array}{l}\text { Dietary factors } \\
\text { investigated }\end{array}$} & \multicolumn{3}{|l|}{ General findings } \\
\hline & & $\begin{array}{l}\text { Wild type K-ras vs. } \\
\text { control }\end{array}$ & $\begin{array}{l}\text { Mutated K-ras vs. } \\
\text { control }\end{array}$ & $\begin{array}{l}\text { Mutated K-ras vs. } \\
\text { wild type } K \text {-ras }\end{array}$ \\
\hline $\begin{array}{l}185 \text { colon } \\
\text { cancer } \\
\text { patients } \\
\text { Kampman et } \\
\text { al, } 2000(45)\end{array}$ & $\frac{\text { Energy intake }}{\text { protein (total or animal) }}$ & & & N.S. \\
\hline \multirow[t]{6}{*}{$\begin{array}{l}1428 \text { colon } \\
\text { cancer } \\
\text { patients and } \\
2406 \text { controls } \\
\text { Slattery et al, } \\
2000 \text { (44) }\end{array}$} & $\begin{array}{l}\text { Dietary fat } \\
\text { high fat, saturated fat, } \\
\text { monounsaturated fat, } \\
\text { polyunsaturated fat. } \\
\text { cholesterol } \\
\text { Insulin-related factors } \\
\text { high carbohydrate, }\end{array}$ & N.S. & N.S. & N.S. \\
\hline & $\begin{array}{l}\text { glycemic index } \\
\text { high refined grains } \\
\text { DNA methylation } \\
\text { factors }\end{array}$ & $\begin{array}{l}\text { N.S. } \\
\text { N.S. }\end{array}$ & $\begin{array}{l}\text { N.S." } \\
\text { Increased association" }\end{array}$ & $\begin{array}{l}\text { N.S.: } \\
\text { N.S.: }\end{array}$ \\
\hline & low folate & Increased association" & N.S. & N.S. \\
\hline & $\begin{array}{l}\text { low vitamin } \mathrm{B}_{6} \\
\text { low vitamin } \mathrm{B}_{12} \text { or } \\
\text { methionine, high }\end{array}$ & Increased association' & N.S. & Inverse association" \\
\hline & $\begin{array}{l}\text { alcohol } \\
\text { Carcinogen } \\
\text { detoxification }\end{array}$ & N.S." & N.S." & N.S." \\
\hline & $\begin{array}{l}\text { low cruciferous } \\
\text { vegetables }\end{array}$ & Increased association" & N.S. & Inverse association" \\
\hline
\end{tabular}

Most mutations (90-95\%) have been found in codons 12 (wild type GGT) and 13 (wild type GGC) of exon 1 and approximately $5 \%$ in codon 61 (wild type CAA) which is located in exon 2 (38-40). A mutation in one of these codons of $K$-ras causes the gene to remain longer in its active state, thereby stimulating cell growth and tissue proliferation (41). The most frequently observed types of mutation in codons 12 and 13 are $\mathrm{G}>\mathrm{A}$ transitions and $\mathrm{G}>\mathrm{T}$ transversions, whereas relatively few $\mathrm{G}>\mathrm{C}$ transversions are found.

\section{DIETARY RISK FACTORS, $\boldsymbol{K}$-RAS GENE MUTATIONS AND COLORECTAL CANCER}

\section{Moleculair epidemiological studies}

To our knowledge, only two cross-sectional case-case studies $(42,43)$ and three longitudinal case-control studies (44-46) on diet and $K$-ras mutations in sporadic colon and rectal cancer have been published and the findings were not consistent (see table 1 ). The most prominent results with respect to the $K$-ras mutation status will be discussed briefly, as of yet without distinguishing between the specific point mutations or affected codons.

Martinez et al (42) observed a significant increased association between low total folate intake (dietary and supplemental, but not dietary alone) and the risk of mutated $K$-ras colorectal adenomas as compared to wild type $K$-ras colorectal adenomas. No associations were observed for energy intake, total or saturated fat, dietary fibre, dietary and total calcium, dietary folate, red meat and alcohol. In a cross-sectional case-case study by O'Brien et al (43), no association was observed between current red meat consumption and rectal cancer risk with respect to the $K$-ras mutation status. Slattery et al (44) observed a significant increased association between prior intake of refined grains and the risk of mutated $K$-ras colon tumours versus controls. In addition, increased associations were observed between low intake of dietary folate and vitamin $\mathrm{B}_{6}$ for associations with wild type 
K-ras colon tumours versus controls. Low consumption of cruciferous vegetables was associated with an increased risk of wild type $K$-ras colon tumours as compared to controls. No associations were observed for saturated fat, monounsaturated fat (MUFA) and polyunsaturated fat (PUFA), cholesterol, carbohydrate, glycemic index, vitamin $B_{12}$, methionine and alcohol with both mutated and wild type $K$-ras tumours versus controls. In a case-control study by Kampman et al (45), no associations were observed in the case-case comparisons between the consumption of total red meat, beef, processed meat, poultry, fish, dairy products, total or saturated fat, cholesterol, total protein, animal protein and calcium, and the $K$-ras mutation status in colon cancer cases. Bautista et al (46) observed a significant inverse association between high intake of MUFA and wild type $K$-ras colorectal tumours as compared to controls. In addition, a significant inverse association was also observed for high intake of calcium with mutated $K$-ras colorectal tumours as compared to controls. No associations were observed for calories, proteins, animal proteins, vegetable protein, total fats, PUFA, saturated fat, cholesterol, carbohydrates, fibre, vegetable fibre, cereal fibre, fruit fibre, legume fibre, phosphorous, sodium, potassium, iron, magnesium, zinc, vitamin $B_{1}$, vitamin $B_{2}$, vitamin $B_{6}$, vitamin $B_{12}$, niacin, folic acid, vitamin $C$, vitamin $A$, retinal, carotene, vitamin $\mathrm{E}$, vitamin $\mathrm{D}$ and colorectal cancer risk with respect to $K$-ras mutation status.

\section{Experimental studies and proposed hypotheses on biological mechanismen}

Results from experimental studies suggest that specific compounds in the diet are relevant for colon and rectal cancer risk with respect to activating mutations in the $K$-ras oncogene. To date, animal and in vitro studies have yielded information on specific mutagenic factors present in our environment. The relevant results will be considered and several mutagenic factors will be discussed with respect to their role in DNA damage that may lead to oncogenic activity of the $K$-ras protein, i.e. heterocyclic aromatic amines (HAA), polycyclic aromatic hydrocarbons (PAH), and nitrosamines from meat proteins, $\omega-6$ PUFA and folate.

Regarding meat intake, animal and in vitro studies have shown that HAA-DNA-adducts can cause transitions and transversions in DNA bases, as observed in the $K$-ras oncogene (47). On the other hand, studies in rodents have suggested that the HAA-adduct formation with DNA is associated with the wild type $K$-ras gene (48). Results from animal experiments are not entirely consistent. PAHs are suggested to be associated with a high prevalence of $\mathrm{G}>\mathrm{T}$ transversions in the $\mathrm{K}$-ras gene (49). High temperature cooking of meat is known to generate HAAs from meat proteins, whereas the process of grilling and smoking of meat forms PAHs as a result of fat dropping on open-flames. Another hypothesis linked to meat consumption involves the possible action of alkylating agents such as nitrosamines, formed from food preservatives in processed meat, on $K$-ras oncogene mutations (50). These agents are thought to induce $G>A$ transitions at codon 12 in the $K$-ras gene, as was observed in rodents (51) and proposed for humans (52).

Experimental studies linking fat intake to DNA damage is confined to studies on MUFA and derivatives of PUFA (11,12). Several of these studies suggest that MUFAs and $\omega-6$ PUFAs have opposite effects on the risk for colon cancer (12). Protective effects of a high MUFA intake, derived mainly from olive oil and a low intake of $\omega-6$ PUFAs, were observed in experimental studies. Takeshita et al (53) found that the incidence of adenocarcinomas of the colon in 1,2-dimethylhydrazine-treated mice was significantly higher in animals fed a diet rich in linoleic acid (main source of $\omega-6$ PUFA) than in animals fed a diet enriched with oleic acid (source of MUFA) or a low-fat diet. To date, no mechanism has been presented that can explain the effect of MUFAs. Peroxidation of $\omega-6$ PUFAs, however, could lead to the accumulation of by-products like malondialdehyde (MDA) and 4-hydroxynonenal (4-HNE). These compounds can react with DNA to form adducts, mainly the pyrimidopurinone adduct 
of deoxyguanosine $(M, G)(54-56)$. The presence of the $M, G$-adducts may result predominantly in $G>A$ and $G>T$ with very few $G>C$ transversions in bacteria $(54,57,58)$. In humans, colorectal biopsies from normal mucosa of participants in the United Kingdom Flexible Sigmoidoscopy Trial and the European Prospective Investigation on Cancer (EPIC) $(n=162)$ were analysed for the presence of $M_{1}$ G-adducts (56). Adduct levels were higher in individuals with adenomas than individuals without adenomas.

For folate, two plausible carcinogenic mechanisms to explain how sub-optimal folate status could pre-dispose to colon cancer have been proposed. Firstly, if the intracellular form of folate, 5, 10-methylenetetrahydrofolate (5, 10-methyleneTHF) is deficient, less methyl groups will be donated to uracil which may result in less available thymine (59). Eventually, the increased uracil incorporation in DNA may lead to DNA strand breaks and chromosome instability. Secondly, a sub-optimal folate status may result in global DNA hypomethylation and possibly in regional hypermethylation of gene promoters, which interferes with gene expression and can impair the expression of tumour suppressor genes, oncogenes and DNA repair genes $(48,59,60)$. DNA strand breaks, global DNA hypomethylation and regional promoter hypermethylation are common events in colon cancer.

\section{AIMS AND SCOPE OF THIS THESIS}

The results from the reports that were described in the previous paragraph were inconsistent, which could be due to the study design, i.e. cross-sectional versus longitudinal studies, selection bias, recall bias or chance due to small sample sizes. In addition, three case-control studies used case-case comparisons to evaluate the aetiological heterogeneity of the risk factors for colon tumours with a wild type or mutated $K$-ras gene, but did not consistently report the case-control comparisons $(44,45,46)$. It should be emphasized that case-case comparisons are useful to detect whether the associations between diet and end points used for cancer cases differ significantly between cases without and cases with the genetic alterations under study. A definite conclusion on how a dietary factor is related to the absence or presence of genetic alterations can be obtained with case-control comparisons, but never with case-case comparisons alone. Therefore, a prospective cohort study design, as used in this thesis, is appropriate to investigate associations between dietary factors and $\mathrm{CRC}$ risk with respect to $K$-ras mutations.

The studies described in this thesis (chapters 2 through 5) are embedded in the ongoing Netherlands Cohort Study (NLCS) on diet and cancer. The NLCS was initiated in 1986 and includes 58,279 men and 62,573 women, at baseline aged between 55 and 69 years old, who completed a self-administered questionnaire on diet, family history of cancer and other risk factors for cancer. The entire cohort is being monitored for cancer occurrence by annual record linkage to the Netherlands Cancer Registry (NCR) and to PALGA, a nationwide database of pathology reports. From 1989 until 1994, with exclusion of the first 2.3 years of follow-up, 819 incident cases of colon and rectal cancer have been identified, and all pathology laboratories in The Netherlands agreed to make these tissue blocks available for this study.

Previous studies on frequencies and specific types of point mutations in the $K$-ras oncogene in CRC in various countries have been reported $(39,41,45,49,50,52,61-65)$. However, these results were often based on small numbers of selected patients, obtained from other populations that may differ from the genetic make-up and the environmental conditions in The Netherlands. Therefore, the first aim of this thesis was to evaluate the frequencies and specific types of mutations in the $K$-ras gene in a large number of unselected, incident colorectal cancer patients, identified in the NLCS. This study is described in chapter 2. 
As described in the previous paragraph the link between consumption of meat and fish and the pattern of $K$-ras mutations in human colon and rectal cancer is not clear. It is hypothesized that high consumption of meat could contribute to the occurrence of point mutations in the K-ras gene, leading to oncogenic activation. In this respect it is expected that $\mathrm{N}$-nitroso compounds, which may be endogenously formed or present in processed meat, induce $\mathrm{G}>\mathrm{A}$ transitions in codons 12 and 13 of the $\mathrm{K}$-ras gene. PACs originating from grilling and smoking of meat may cause G>T transversions, whereas HAAs, which are generated by high temperature cooking of meat proteins, may lead to transitions and transversions of DNA bases in the K-ras gene. These hypotheses form the basis of the associations between different types of fresh meat, meat products and fish, and the risk of CRC with or without specific point mutations in the $K$-ras gene, which were studied and described in chapter 3.

For the intake of fats and fatty acids and the risk for $K$-ras mutations, associations are inconsistent (unclear, not well-defined). Based on experimental studies it is hypothesized that peroxidation of $\omega-6$ polyunsaturated fatty acids may lead to accumulation of malondialdehyde and 4-hydroxynonenal, that could form DNA adducts. The adducts could result in $G>A$ transitions and $G>T$ transversions. The associations of total, saturated, and MUFA and PUFA intake with the risk of CRC with or without specific point mutations in the $K$-ras gene were studied and described in chapter 4 .

Folate plays an important role in one-carbon metabolism, in DNA synthesis and in methylation of DNA and proteins. Since a deficiency in intermediate folate metabolites leads to a reduced availability of thymine for DNA synthesis, and an increased incorporation of uracil results in more DNA strand breaks, genomic instability may be generated. In addition, folate deficiency may also result in global genome hypomethylation and regional hypermethylation in gene promoters. The latter mechanism inhibits gene expression, and has been demonstrated to evoke DNA repair deficiency. Based on these hypotheses, the association between dietary folate intake and the risk of CRC with or without K-ras mutations is studied and described in chapter 5 .

Finally, the results and their implications are discussed in chapter 6.

\section{REFERENCES}

1. Potter JD. (1999) Colorectal cancer: molecules and populations. J Natl Cancer Inst, 91(11), 916-32.

2. Potter JD, Slattery ML, Bostick RM, Gapstur SM. (1993) Colon cancer: a review of the epidemiology. Epidemiol Rev, 15(2), 499-545.

3. Chyou PH, Nomura AM, Stemmermann GN. (1996) A prospective study of colon and rectal cancer among Hawaii Japanese men. Ann Epidemiol, 6(4), 276-82.

4. Le Marchand L, Wilkens LR, Hankin JH, Kolonel LN, Lyu LC. (1997) A case-control study of diet and colorectal cancer in a multiethnic population in Hawaii (United States): lipids and foods of animal origin. Cancer Causes Control, 8(4), 637-48.

5. Lichtenstein P. Holm NV, Verkasalo PK, et al. (2000) Environmental and heritable factors in the causation of cancer-- analyses of cohorts of twins from Sweden, Denmark, and Finland. N Engl J Med, 343(2), 78-85.

6. Potter JD. (1996) Nutrition and colorectal cancer. Cancer Causes Control, 7(1), 127-46.

7. Slattery ML, Boucher KM, Caan BJ, Potter JD, Ma KN. (1998) Eating patterns and risk of colon cancer. Am J Epidemiol, 148(1), 4-16.

8. Goldbohm RA, van den Brandt PA, van 't Veer P, et al. (1994) A prospective cohort study on the relation between meat consumption and the risk of colon cancer. Cancer Res, 54(3), 718-23. 
9. Willett WC, Stampfer MJ, Colditz GA, Rosner BA, Speizer FE. (1990) Relation of meat, fat, and fiber intake to the risk of colon cancer in a prospective study among women. $N$ Engl J Med, 323(24), 1664-72.

10. Howe GR, Aronson KJ, Benito E, et al. (1997) The relationship between dietary fat intake and risk of colorectal cancer: evidence from the combined analysis of 13 casecontrol studies. Cancer Causes Control, 8(2), 215-28.

11. Zock PL, Katan MB. (1998) Linoleic acid intake and cancer risk: a review and metaanalysis. Am J Clin Nutr, 68(1), 142-53.

12. Bartsch H, Nair J, Owen RW. (1999) Dietary polyunsaturated fatty acids and cancers of the breast and colorectum: emerging evidence for their role as risk modifiers. Carcinogenesis, 20(12), 2209-18.

13. Slattery ML, Potter JD, Duncan DM, Berry TD. (1997) Dietary fats and colon cancer: assessment of risk associated with specific fatty acids. Int J Cancer, 73(5), 670-7.

14. Slattery ML, Caan BJ, Potter JD, et al. (1997) Dietary energy sources and colon cancer risk. Am J Epidemiol, 145(3), 199-210.

15. Norat T, Lukanova A, Ferrari P, Riboli E. (2002) Meat consumption and colorectal cancer risk: Dose-response meta- analysis of epidemiological studies. Int $J$ Cancer, 98(2), 241-56.

16. Gerhardsson de Verdier M, Hagman U, Peters RK, Steineck G, Overvik E. (1991) Meat, cooking methods and colorectal cancer: a case-referent study in Stockholm. Int $J$ Cancer, 49(4), 520-5.

17. Giovannucci E, Willett WC. (1994) Dietary factors and risk of colon cancer. Ann Med, 26(6), 443-52.

18. Negri E, Franceschi S, Parpinel M, La Vecchia C. (1998) Fiber intake and risk of colorectal cancer. Cancer Epidemiol Biomarkers Prev, 7(8), 667-71.

19. Ghadirian P. Lacroix A, Maisonneuve P, et al. (1997) Nutritional factors and colon carcinoma: a case-control study involving French Canadians in Montreal, Quebec, Canada. Cancer, 80(5), 858-64.

20. Bergsma-Kadijk JA, van 't Veer P, Kampman E, Burema J. (1996) Calcium does not protect against colorectal neoplasia. Epidemiology, 7(6), 590-7.

21. Martinez ME, Willett WC. (1998) Calcium, vitamin D, and colorectal cancer: a review of the epidemiologic evidence. Cancer Epidemiol Biomarkers Prev,7(2), 163-8.

22. Giovannucci E, Stampfer MJ, Colditz GA, et al. (1998) Multivitamin use, folate, and colon cancer in women in the Nurses' Health Study. Ann Intern Med, 129(7), 517-24.

23. Glynn SA, Albanes D, Pietinen P, et al. (1996) Colorectal cancer and folate status: a nested case-control study among male smokers. Cancer Epidemiol Biomarkers Prev. 5(7), 487-94

24. Fuchs CS, Willett WC, Colditz GA, et al. (2002) The influence of folate and multivitamin use on the familial risk of colon cancer in women. Cancer Epidemiol Biomarkers Prev. 11(3), 227-34

25. Giovannucci E, Rimm EB, Ascherio A, Stampfer MJ, Colditz GA, Willett WC. (1995) Alcohol, low-methionine--low-folate diets, and risk of colon cancer in men. J Natl Cancer Inst, 87(4), 265-73.

26. Potter JD, McMichael AJ. (1986) Diet and cancer of the colon and rectum: a casecontrol study. J Natl Cancer Inst, 76(4), 557-69.

27. Wei EK, Giovannucci E, Wu K, et al. (2004) Comparison of risk factors for colon and rectal cancer. Int.J.Cancer, 108, 433-442.

28. Goldbohm RA, Van den Brandt PA, Van 't Veer P, Dorant E, Sturmans F, Hermus RJ. (1994) Prospective study on alcohol consumption and the risk of cancer of the colon and rectum in the Netherlands. Cancer Causes Control, 5(2), 95-104. 
29. Pedersen A, Johansen C, Gronbaek M. (2003) Relations between amount and type of alcohol and colon and rectal cancer in a Danish population based cohort study. Gut, 52(6), 861-7.

30. Bidoli E, Franceschi S, Talamini R, Barra S, La Vecchia C. (1992) Food consumption and cancer of the colon and rectum in north-eastern Italy. Int J Cancer, 50(2), 223-9.

31. Longnecker MP, Orza MJ, Adams ME, Vioque J, Chalmers TC. (1990) A meta-analysis of alcoholic beverage consumption in relation to risk of colorectal cancer. Cancer Causes Control, 1(1), 59-68.

32. Ahnen DJ. (1990) Lessons from the genetics of colon cancer. Scand J Gastroenterol Suppl, 175, 166-76.

33. Kinzler KW, Vogelstein B. (1996) Lessons from hereditary colorectal cancer. Cell, 87(2), 159-70.

34. Hill MJ, Morson BC, Bussey HJ. (1978) Aetiology of adenoma--carcinoma sequence in large bowel. Lancet, 1(8058),245-7.

35. Fearon ER, Vogelstein B. (1990) A genetic model for colorectal tumorigenesis. Cell, 61(5), 759-67.

36. Kinzler KW, Vogelstein B. (1998) Landscaping the cancer terrain. Science, 280(5366), 1036-7.

37. Lengauer C, Kinzler KW, Vogelstein B. (1998) Genetic instabilities in human cancers. Nature, 396(6712), 643-9.

38. Vogelstein B, Fearon ER, Hamilton SR, et al. (1988) Genetic alterations during colorectal-tumor development. N Engl J Med, 319(9), 525-32.

39. Breivik J, Meling GI, Spurkland A, Rognum TO, Gaudernack G. (1994) K-ras mutation in colorectal cancer: relations to patient age, sex and tumour location. $\mathrm{Br} J$ Cancer, 69(2), 367-71.

40. Kislitsin D, Lerner A, Rennert G, Lev Z. (2002) K-ras mutations in sporadic colorectal tumors in Israel: unusual high frequency of codon 13 mutations and evidence for nonhomogeneous representation of mutation subtypes. Dig Dis Sci, 47(5), 1073-9.

41. Moerkerk P, Arends JW, van Driel M, de Bruine A, de Goeij A, ten Kate J. (1994) Type and number of Ki-ras point mutations relate to stage of human colorectal cancer. Cancer Res, 54(13), 3376-8.

42. Martinez ME, Maltzman T, Marshall JR, et al. (1999) Risk factors for Ki-ras protooncogene mutation in sporadic colorectal adenomas. Cancer Res, 59(20), 5181-5.

43. O'Brien H, Matthew JA, Gee JM, et al. (2000) K-ras mutations, rectal crypt cells proliferation, and meat consumption in patients with left-sided colorectal carcinoma. Eur $J$ Cancer Prev, 9(1), 41-7.

44. Slattery ML, Curtin K, Anderson K, et al. (2000) Associations between dietary intake and Ki-ras mutations in colon tumors: a population-based study. Cancer Res, 60(24), 6935-41.

45. Kampman E, Voskuil DW, van Kraats AA, et al. (2000) Animal products and K-ras codon 12 and 13 mutations in colon carcinomas. Carcinogenesis, 21(2), 307-9.

46. Bautista D, Obrador A, Moreno V, et al. (1997) Ki-ras mutation modifies the protective effect of dietary monounsaturated fat and calcium on sporadic colorectal cancer. Cancer Epidemiol Biomarkers Prev, 6(1), 57-61.

47. Vineis P. McMichael A. (1996) Interplay between heterocyclic amines in cooked meat and metabolic phenotype in the etiology of colon cancer. Cancer Causes Control, 7(4), 479-86.

48. Greenwald P. Kelloff GJ, Boone CW, McDonald SS. (1995) Genetic and cellular changes in colorectal cancer: proposed targets of chemopreventive agents. Cancer Epidemiol Biomarkers Prev, 4(7), 691-702. 
49. Urosevic N, Krtolica K, Skaro-Milic A, Knezevic-Usaj S, Dujic A. (1993) Prevalence of G-to-T transversions among K-ras oncogene mutations in human colorectal tumors in Yugoslavia. Int J Cancer, 54(2), 249-54.

50. Bingham SA, Pignatelli B, Pollock JR, et al. (1996) Does increased endogenous formation of $\mathrm{N}$-nitroso compounds in the human colon explain the association between red meat and colon cancer? Carcinogenesis, 17(3), 515-23.

51. Jacoby RF, Alexander RJ, Raicht RF, Brasitus TA. (1992) K-ras oncogene mutations in rat colon tumors induced by $\mathrm{N}$-methyl- $\mathrm{N}$ - nitrosourea. Carcinogenesis, 13(1), 45-9.

52. Hughes R, Cross AJ, Pollock JR, Bingham S. (2001) Dose-dependent effect of dietary meat on endogenous colonic $\mathrm{N}$ - nitrosation. Carcinogenesis, 22(1), 199-202.

53. Takeshita M, Ueda H, Shirabe K, Higuchi Y, Yoshida S. (1997) Lack of promotion of colon carcinogenesis by high-oleic safflower oil. Cancer, 79(8), 1487-93.

54. Marnett LJ. (2000) Oxyradicals and DNA damage. Carcinogenesis, 21(3), 361-70.

55. Sharma RA, Ireson CR, Verschoyle RD, et al. (2001) Effects of dietary curcumin on glutathione S-transferase and malondialdehyde-DNA adducts in rat liver and colon mucosa: relationship with drug levels. Clin Cancer Res, 7(5), 1452-8.

56. Leuratti C, Watson MA, Deag EJ, et al. (2002) Detection of malondialdehyde DNA adducts in human colorectal mucosa: relationship with diet and the presence of adenomas. Cancer Epidemiol Biomarkers Prev, 11(3), 267-73.

57. Burcham PC. (1999) Internal hazards: baseline DNA damage by endogenous products of normal metabolism. Mutat Res, 443(1-2), 11-36.

58. Fink SP, Reddy GR, Marnett LJ. (1997) Mutagenicity in Escherichia coli of the major DNA adduct derived from the endogenous mutagen malondialdehyde. Proc Natl Acad Sci U S A, 94(16), 8652-7.

59. Povey AC, Badawi AF, Cooper DP, et al. (2002) DNA alkylation and repair in the large bowel: animal and human studies. J Nutr, 132(11 Suppl), 3518S-3521S.

60. Esteller M, Toyota M, Sanchez-Cespedes M, et al. (2000) Inactivation of the DNA repair gene O6-methylguanine-DNA methyltransferase by promoter hypermethylation is associated with $\mathrm{G}$ to $\mathrm{A}$ mutations in $\mathrm{K}$-ras in colorectal tumorigenesis. Cancer Res, 60(9), 2368-71.

61. Beranek M, Bures J, Palicka V, Jandik P, Langr F, Nejedla E. (1999) A relationship between K-ras gene mutations and some clinical and histologic variables in patients with primary colorectal carcinoma. Clin Chem Lab Med, 37(7), 723-7.

62. Cerottini JP, Caplin S, Saraga E, Givel JC, Benhattar J. (1998) The type of K-ras mutation determines prognosis in colorectal cancer. Am J Surg, 175(3), 198-202.

63. Martinez-Garza SG, Nunez-Salazar A, Calderon-Garciduenas AL, Bosques-Padilla J, Niderhauser-Garcia A, Barrera-Saldana HA. (1999) Frequency and clinicopathology associations of $\mathrm{K}$-ras mutations in colorectal cancer in a northeast Mexican population. Dig Dis, 17(4), 225-9.

64. Samowitz WS, Curtin K, Schaffer D, Robertson M, Leppert M, Slattery ML. (2000) Relationship of Ki-ras mutations in colon cancers to tumor location, stage, and survival: a population-based study. Cancer Epidemiol Biomarkers Prev, 9(11), 1193-7

65. Span M, Moerkerk PT, De Goeij AF, Arends JW. (1996) A detailed analysis of K-ras point mutations in relation to tumor progression and survival in colorectal cancer patients. Int J Cancer, 69(3), 241-5. 
$K$-ras oncogene mutations in
sporadic colorectal cancer in
The Netherlands Cohort Study 


\title{
K-ras oncogene mutations in sporadic colorectal cancer in The Netherlands Cohort Study
}

\author{
Mirian Brink ${ }^{1}$ \\ Anton FPM de Goeij ${ }^{2}$ \\ Matty P Weijenberg' \\ Guido MJM Roemen ${ }^{3}$ \\ Marjolein HFM Lentjes ${ }^{3}$ \\ Marco MM Pachen ${ }^{3}$ \\ Kim M Smits ${ }^{1}$ \\ Adriaan $\mathrm{P}$ de Bruinne ${ }^{2}$ \\ R Alexandra Goldbohm ${ }^{4}$ \\ Piet A van den Brandt ${ }^{1}$
}

\footnotetext{
'Nutrition and Toxicology Research Institute Maastricht (NUTRIM), Dept. of Epidemiology,

Maastricht University, The Netherlands

${ }^{2}$ Research Institute Growth and Development (GROW), Dept. of Pathology, Maastricht University, The Netherlands

${ }^{3}$ NUTRIM, Dept. of Pathology, Maastricht University, The Netherlands

${ }^{4}$ TNO Nutrition and Food Research, Zeist, The Netherlands
} 


\section{ABSTRACT}

Activation of $K$-ras oncogene has been implicated in colorectal carcinogenesis, being mutated in $30-60 \%$ of the adenocarcinomas. In this study, 737 incident colorectal cancer (CRC) patients, originating from 120,852 men and women (55-69 years at baseline) participating in The Netherlands Cohort Study (NLCS), were studied in order to evaluate subgroups with respect to $K$-ras mutation status.

Mutation analysis of the exon 1 fragment of the $K$-ras oncogene, spanning codons 8 to 29, was performed on archival colorectal adenocarcinoma samples of all patients using macrodissection, nested PCR and direct sequencing of purified fragments. The method of mutation detection was validated by the confirmation of reported $K$-ras status in CRC cell lines, a good correlation between fresh-frozen and routinely-fixed, paraffin-embedded tissue, a detection limit of $5 \%$ mutated DNA and a good reproducibility. Various types of $K$-ras mutations were evaluated with respect to family history of CRC, tumour sublocalisation, Dukes' stage and tumour differentiation.

In $37 \%(271 / 737)$ of the patients, the exon 1 fragment of $K$-ras gene was found to be mutated. The predominant mutations are $\mathrm{G}>\mathrm{A}$ transitions and $\mathrm{G}>\mathrm{T}$ transversions, and codons 12 and 13 are the most frequently affected codons. Patients with a rectal tumour were found to have the highest frequency of $G>T$ transversions as compared to patients with a colon or rectosigmoid tumour. This difference appeared to be confined to women with a rectal tumour harbouring $G>T$ transversions. No significant differences were observed for Dukes' stage with respect to types of K-ras mutation, which does not support direct involvement of the $K$-ras oncogene in adenocarcinoma progression.

The equal distribution of $K$-ras mutations among cases with or without a family history of CRC argues against an important role for this mutation in familial colorectal cancer, and could imply that $K$-ras mutations are more likely involved in environmental mechanisms of colorectal carcinogenesis. 
Chapter 2 


\section{INTRODUCTION}

The development of colorectal cancer (CRC) is a multistep process characterised by the accumulation of genetic alterations $(1,2)$. The Fearon and Vogelstein model assumes the involvement of the APC (Adenomatous Polyposis Coli) gene in adenoma formation and the $K$-ras oncogene in the transition from intermediate adenomas to carcinomas in sporadic CRC (1).

The $K$-ras oncogene has been found mutated in $10-15 \%$ of the screened adenomas smaller than $1 \mathrm{~cm}$ and in $30-60 \%$ of adenomas larger than $1 \mathrm{~cm}$. Also, $30-60 \%$ of the adenocarcinomas has a $K$-ras mutation $(3,5)$. It was suggested, therefore, that a mutated $K$-ras gene contributes to the transition of an intermediate adenoma to a late adenoma or carcinoma (2). The $K$-ras gene product, a $21 \mathrm{kD}$ protein located at the inner plasma membrane, is involved in the transduction of mitogenic signals. The Ras protein is activated transiently as a response to extracellular signals such as growth factors, cytokines and hormones that stimulate cell surface receptors (6). The hallmark of Ras function is a switch between an inactive state, in which the proteins are bound to guanosine-diphosphates (GDP) and an active state in which conversion to guanosine-triphosphates (GTP) has occurred. This transit is governed by two types of regulatory proteins: GDP-GTP exchange factors that catalyse the GDP/GTP exchange and GTPase-activating proteins that enhance the intrinsic capacity of Ras proteins to hydrolyse GTP into GDP, thereby returning Ras to the inactive state (7).

Mutant, activated forms of Ras proteins have an impaired intrinsic GTPase activity, which renders the protein resistant to inactivation by regulatory GTPase-activating proteins (4). Approximately $90 \%$ of the activating mutations is found in codons 12 (wild type GGT) and 13 (wild type GGC) of exon 1 and around $5 \%$ in codon 61 (wild type CAA) located in exon $2(8,10)$. Previous studies from various countries have revealed specific point mutations in codons 12 and 13 . The most frequently observed types of mutations are $G>A$ transitions (11) and G>T transversions (12) and these alterations were found associated with sex and sublocalisation of the tumour (9).

To date, frequencies and specific types of point mutations in the $K$-ras oncogene in CRC have been investigated in several studies $(4,5,10,13)$. These reports were generally based on small numbers of selected patients. In the current study, however, the frequency of $K$-ras mutations is studied in a large series of unselected, incident CRC patients from The Netherlands identified in a prospective cohort study. Potential differences in family history of CRC, tumour sublocalisation, Dukes' stage and tumour differentiation with respect to presence and type of the $K$-ras mutations are studied.

\section{MATERIALS AND METHODS}

\section{Study Population}

The participants in this study are incident CRC cases from The Netherlands Cohort Study on diet and cancer (NLCS). The NLCS has been described in detail elsewhere (14). Briefly, the prospective study was initiated in 1986 and includes 58,279 men and 62,573 women, aged between 55 and 69 years old, who completed a self-administered questionnaire on diet, family history of cancer and other risk factors for cancer at baseline. The entire cohort is being monitored for cancer occurrence by annual record linkage to The Netherlands Cancer Registry (NCR) and to PALGA, a nationwide database of pathology reports (15). From 1989 until 1994, with exclusion of the first 2.3 years of follow-up due to incomplete nationwide coverage of PALGA, 819 incident cases with histological confirmed CRC have been identified. The PALGA database was also used to identify the location of 
tumour tissue storage in the Dutch pathology laboratories. CRC was classified according to site as follows: proximal colon, i.e. cecum through transverse colon (ICD-O codes: 153.0, $153.1,153.4,153.5,153.6)$; distal colon: splenic flexure through sigmoid colon (ICD-O codes: 153.2, 153.3, 153.7); rectosigmoid (ICD-O code 154.0) and rectum (ICD-O code 154.1). Information about age at diagnosis, sex and family history of CRC (at baseline) was retrieved from the NLCS database. Information about tumour sublocalisation, Dukes' stage and differentiation of the tumour was retrieved from the NCR database.

Table 1 Characteristics of CRC cases ( $\mathrm{N}=737)$ subdivided into cases without a $K$-ras $(\mathrm{N}=466)$ mutation and cases with at least one $K$-ras mutation $(\mathrm{N}=271)$

\begin{tabular}{lllll}
\hline & Total $(\mathrm{N}=737)$ & Wild type K-ras $(\mathrm{N}=466)$ & \multicolumn{1}{c}{ K-ras mutation (N=271) } & p-value" \\
\hline Age at diagnosis (mean $\pm \mathrm{SD})$ & $67.95 \pm 4.26$ & $67.75 \pm 4.21$ & $68.29 \pm 4.32$ & 0.10 \\
Sex (\% Men) & $410(56 \%)$ & $257(55 \%)$ & $153(57 \%)$ & 0.73 \\
Family history of CRC (\% Yes) & $76(10 \%)$ & $53(11 \%)$ & $23(9 \%)$ & 0.21 \\
\hline
\end{tabular}

"comparing cases with at least one $K$-ras mutation to cases without a $K$-ras mutation

\section{Tissue Samples}

Tumour material was collected after approval by the Medical Ethical Committees (MEC) of the Maastricht University, PALGA and the NCR. Subsequently, all pathology laboratories in The Netherlands agreed to make relevant tissue samples available for this study. Tumour tissue sample collection started in August, 1999 and was completed in December, 2001. The 819 tissue samples were distributed among 54 pathology laboratories throughout The Netherlands, and only $44(5 \%)$ tumour tissue samples could not be traced. Finally, 775 $(95 \%)$ of the eligible tissue samples have been retrieved and $737(90 \%)$ of the tissue samples contained sufficient tumour material as confirmed by a pathologist (AdB) and hence were available for molecular analyses. Archival tissue sample blocks were registered and coded using a consecutive, unique identification number.

Five CRC cell lines, i.e. HT29, Colo205, CaCo2, SW480 and HCT116 (American Type Culture Collection (ATCC), Rockville, Md, USA) were used to check the specificity of $K$-ras mutation detection. In order to validate mutation analysis on paraffin-embedded tissue, 10

Table 2 Number and type of mutations, affected codons, and corresponding altered amino acids in exon 1 of the $K$-ras gene

\begin{tabular}{|c|c|c|c|c|c|}
\hline Codon' & $\begin{array}{l}\text { Type of point } \\
\text { mutation* }\end{array}$ & $\begin{array}{l}\text { Number of point } \\
\text { mutations }\end{array}$ & $\begin{array}{l}\text { Wild type codon" } \\
\text { (amino acidb) }\end{array}$ & $\begin{array}{l}\text { Mutated codona (amino } \\
\text { acidt) }\end{array}$ & $\begin{array}{l}\text { Putative altered } \\
\text { amino acid }\end{array}$ \\
\hline 8 & $A>G$ & $3(1 \%)$ & GTA (val) & GTG (val) & 3 \\
\hline 9 & Insertion & $1(0.4 \%)$ & GTT (val) & GTG (val)-GAG (glz)-CTT (leu) & 1 \\
\hline 10 & G>A & $1(0.4 \%)$ & GGA (gly) & AGA (arg) & 1 \\
\hline \multirow[t]{5}{*}{12} & $G>A$ & $91(33 \%)$ & GGT (gly) & GAT (asp) & $75(37 \%)$ \\
\hline & $G>T$ & $87(31 \%)$ & & GTT (val) & $70(35 \%)$ \\
\hline & & & & TGT (cys) & $17(8 \%)$ \\
\hline & $\mathrm{G}>\mathrm{C}$ & $23(8 \%)$ & & GCT (ala) & $16(8 \%)$ \\
\hline & & & & CGT (arg) & $7(3 \%)$ \\
\hline 13 & $G \gg A$ & $58(21 \%)$ & GGC (gly) & GAC (asp) & $58(94 \%)$ \\
\hline & $\begin{array}{l}G>T \\
G>C\end{array}$ & $3(1 \%)$ & & TGC (arg) & $3(5 \%)$ \\
\hline 15 & $G>A$ & $1(0.4 \%)$ & & $\begin{array}{l}\text { CGC (cys) } \\
\text { AGC (ser) }\end{array}$ & $1(2 \%)$ \\
\hline 16 & $G>A$ & $10.4 \%$ & AAG (lys) & AAA (lvs) & 1 \\
\hline 19 & $G>A$ & $1(0.4 \%)$ & TTG (leu) & TTA (leu) & 1 \\
\hline 20 & $C>T$ & $8(3 \%)$ & ACG (thr) & ATG (met) & 8 \\
\hline 25 & $G>A$ & $2(0.8 \%)$ & CAG (glu) & CAA (glu) & 2 \\
\hline
\end{tabular}

- For 10 patients, 2 mutations were found and these are included in this table

' $g l y=g l y c i n e$, asp=aspartic acid, ser=serine, val=valine, cys=cysteine, alazalanine, arg=arginine, thr=threonine, met=methionine. glu=glutamine,lu=leucine, glz=glutamic acid

- The insertion is 6 nucleobides (TGGAGC), located after the first position of codon 9, resulting in 3 altered codons 
fresh CRC specimens were divided into two adjacent tissue blocks, one of which was freshfrozen, and one routinely-fixed and embedded in paraffin. These specimens were obtained from patients who did not participate in the NLCS.

\section{DNA Isolation}

Sections $(5 \mu \mathrm{m})$ were cut from paraffin-embedded tumour tissue blocks and stained with haematoxilin \& eosin (H\&E) for histopathological examination. For DNA isolation, five $20 \mu \mathrm{m}$ sections of tumour tissue were used. Deparaffination of the sections was performed and, using the H\&E section as a reference, tumour tissue was macrodissected from the normal colonic epithelium and scraped off.

Genomic DNA was extracted from macrodissected tumour tissue using the Puregene DNA isolation kit (Gentra Systems). Briefly, $475 \mu$ cell lysis solution and $25 \mu$ proteinase K stock solution ( $20 \mathrm{mg} / \mathrm{ml}$, obtained from Qiagen, St. Louis, MO, USA) were added to the tissue samples and incubated overnight at $55^{\circ} \mathrm{C}$. Subsequently, DNA was extracted for 72 hours at $37^{\circ} \mathrm{C}$, protein was removed and DNA was precipitated using $100 \%$ 2-propanol and dissolved in hydration buffer. The DNA concentration and purity was measured at 260 and $280 \mathrm{~nm}$.

DNA from fresh, unfixed CRC cell lines and the fresh-frozen tissue samples was extracted as described for paraffin-embedded sections.

\section{Mutation Analysis}

An exon 1 fragment of the $K$-ras gene was amplified from isolated, genomic DNA using a nested PCR approach. In the first reaction, a fragment of 179 base pairs (bp) was generated, using the sense primer 5'-AGG CCT GCT GAA AAT GAC TGA ATA-3' and antisense primer $5^{\prime}$-CTG TAT CAA AGA ATG GTC CTG CAC-3'. The annealing temperature was $58^{\circ} \mathrm{C}$. The resulting fragment was used as a template to amplify a $114 \mathrm{bp}$ fragment spanning codons 8 to 29. This PCR is performed using the biotinylated, sense primer 5'-AAA ATG ACT GAA TAT AAA CTT GTG G-3' and the antisense primer 5'-CTC TAT TGT TGG ATC ATA TTC GTC-3' at an annealing temperature of $50^{\circ} \mathrm{C}$. The inside products were checked for purity and size by electrophoresis on a $2 \%$ agarose gel and subsequently used for direct sequencing.

Mutations in the exon 1 fragment of the $K$-ras gene were detected by direct sequencing with a solid phase sequencing kit (Amersham Pharmacia) using the ALFexpress II DNA sequencer (Pharmacia Biotech). In brief, the biotinylated PCR product is captured on a sequencing comb coated with streptavidin. After removal of the non-biotinylated strands by alkaline denaturation, the remaining immobilized strand was used as a template for dideoxy sequencing reactions with a Cy5 labeled primer 5'-CTC TAT TGT TGG ATC ATA TTC GTC CAC-3' and T7 DNA polymerase. The sequence profile is analysed on the ALFexpress II DNA Analysis System. Evaluation was independently performed using ALFwin software (Amersham Pharmacia Biotech) by two observers, based on the criterium that at an increase of least a $5 \%$ is observed for the mutant peak as well as an a decrease of at least a $5 \%$ in the wild type peak, relative to the wild type pattern in the same sequence run. Dataentry was performed blindly by two independent observers.

The mutation detection limit was determined by mixing wild type DNA from the cell line $\mathrm{CaCo} 2$ and the homozygously mutated cell line SW 480 in amounts varying from $0-100 \%$.

\section{Statistical Analysis}

The overall frequency of $K$-ras mutations as well as the type of mutation and affected codon was computed for all 737 cases with respect to age at diagnosis, sex, family history of CRC, tumour sublocalisation, Dukes' stage and tumour differentiation. Differences in mean 
Table 3 Characterisation of $K$-ras mutations at gene and codon level according to tumour sublocalisation, Dukes' stage and differentiation of the tumour

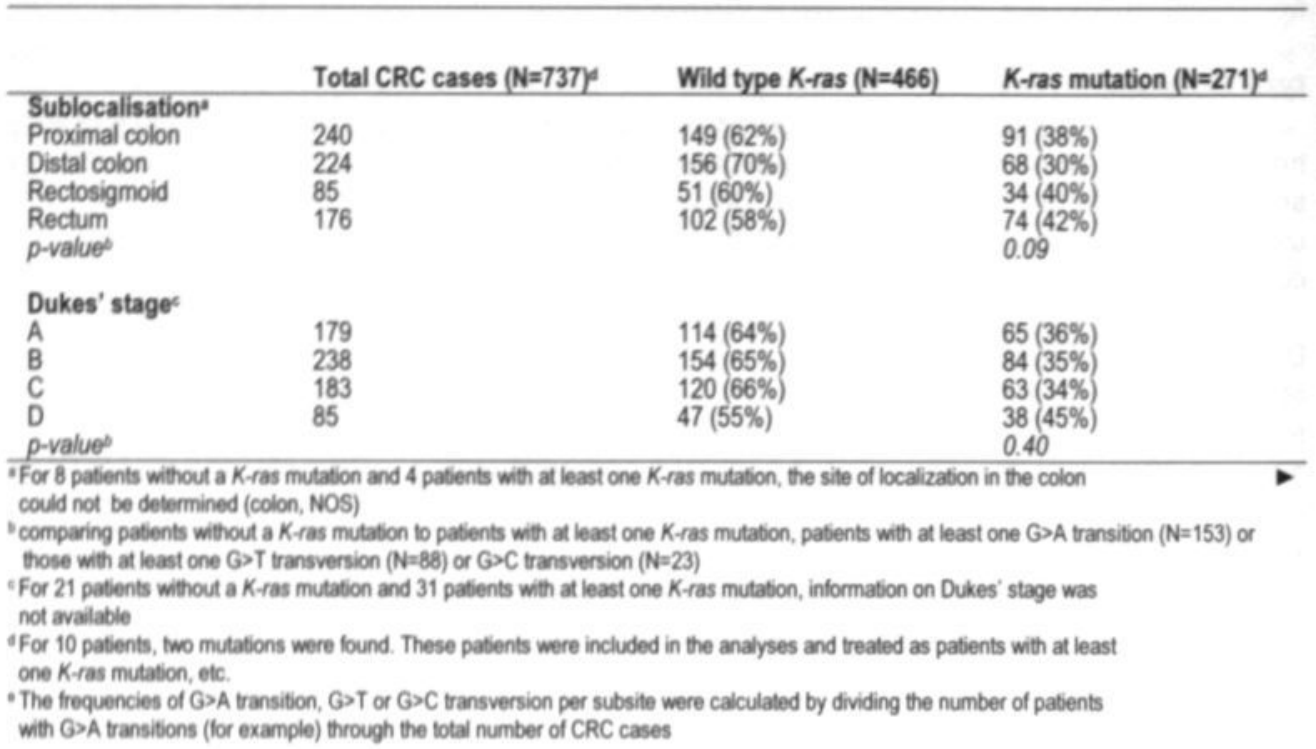

values of age at diagnosis as a continuous variable was evaluated using the Student $t$-test. Differences in the categorical variables sex, family history of CRC, tumour sublocalisation, Dukes' stage and tumour differentiation between patients without and with $K$-ras mutations were evaluated for significance with the $x^{2}$-test. In addition, differences in tumour sublocalisation, Dukes' stage and tumour differentiation between patients without a K-ras

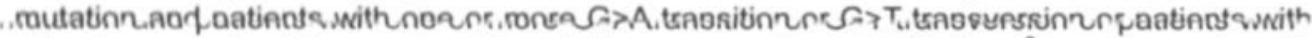
at least one codon 12 or codon 13 mutation were evaluated with the $x^{2}$-test. A p-value of 0.05 or less was considered statistically significant. Statistical analyses were performed using the SPSS software (version 9.0).

\section{RESULTS}

\section{Validation of Techniques}

In the colorectal cancer cell lines HT29, Colo205 and CaCo2, wild type K-ras was found, whereas homozygously mutated alleles in SW480 and heterozygously mutated alleles in HCT116 cells were revealed with direct sequence analysis. For the SW480, line, a GGT to GTT mutation in codon 12 was observed and for the HCT116 line, a GGC to GAC mutation in codon 13.

The effect of tissue processing was assessed by comparing an adjacent fresh-frozen and a paraffin-embedded tissue block in a series of 10 fresh colon tumour specimens. In nine specimens, the $K$-ras status in the paraffin-embedded tissue was identical to fresh, unfixed tissue, i.e. six specimens with wild type $K$-ras, one with a $G>T$ transversion at the second position of codon 12, one with a $\mathrm{G}>\mathrm{C}$ transversion at the second position of codon 12 and one with a $\mathrm{G}>\mathrm{C}$ transversion at the second position of codon 13. In one specimen, a $\mathrm{G}>\mathrm{C}$ transversion at the third position of codon 19 was observed in the routinely-fixed, paraffin-embedded tissue, but not in DNA extracted from the fresh tissue. 


\begin{tabular}{|c|c|c|c|c|}
\hline \multicolumn{3}{|c|}{ Point mutation } & \multicolumn{2}{|c|}{ Affected codon } \\
\hline $\begin{array}{l}\text { G>A transition } \\
(\mathrm{N}=153)^{4} .\end{array}$ & $\begin{array}{l}\text { G>T transversion } \\
(\mathrm{N}=88)^{4} \text {. }\end{array}$ & $\begin{array}{l}\mathrm{G}>\mathrm{C} \text { transversion } \\
(\mathrm{N}=23)^{4}\end{array}$ & Codon $12(\mathrm{~N}=195)^{20}$ & Codon $13(\mathrm{~N}=62)^{2}$. \\
\hline $\begin{array}{l}22(23 \%) \\
38(17 \%) \\
20(24 \%) \\
37(21 \%) \\
0.39\end{array}$ & $\begin{array}{l}27(11 \%) \\
20(9 \%) \\
12(14 \%) \\
28(16 \%) \\
0.22\end{array}$ & $\begin{array}{l}7(3 \%) \\
6(3 \%) \\
2(2 \%) \\
9(5 \%) \\
0.48\end{array}$ & $\begin{array}{l}61(25 \%) \\
50(22 \%) \\
21(25 \%) \\
60(34 \%) \\
0.07\end{array}$ & $\begin{array}{l}26(11 \%) \\
12(5 \%) \\
12(14 \%) \\
11(6 \%) \\
0.03\end{array}$ \\
\hline $\begin{array}{l}46(26 \%) \\
39(16 \%) \\
37(20 \%) \\
16(19 \%) \\
0.13\end{array}$ & $\begin{array}{l}15(8 \%) \\
36(15 \%) \\
17(9 \%) \\
15(18 \%) \\
0.04\end{array}$ & $\begin{array}{l}2(1 \%) \\
7(3 \%) \\
9(5 \%) \\
4(5 \%) \\
0.17\end{array}$ & $\begin{array}{l}46(26 \%) \\
61(26 \%) \\
43(23 \%) \\
26(31 \%) \\
0.68\end{array}$ & $\begin{array}{l}17(9 \%) \\
18(8 \%) \\
17(9 \%) \\
8(9 \%) \\
0.88\end{array}$ \\
\hline
\end{tabular}

The detection limit of mutation detection was determined by mixing wild type DNA isolated from the $\mathrm{CaCo} 2$ cell line with decreasing concentrations of mutated DNA which was prepared from the homozygously mutated colorectal cell line SW480. The lowest level of detection was five percent mutant DNA in a background of wild type DNA as found in three independent experiments.

To establish the reproducibility of the mutation analysis, 32 NLCS adenocarcinoma specimens were subjected twice to the complete procedure, from tissue sectioning to DNA sequencing. In $88 \%(28 / 32)$ of the samples, the same $K$-ras status was observed in the duplicate experiments.

\section{Types of Mutations}

In the exon 1 fragment of the $K$-ras oncogene, a total of 281 mutations was found in 271 $(37 \%)$ out of 737 patients. No significant differences were observed in mean age at diagnosis $(67.75 \pm 4.21$ versus $68.29 \pm 4.32)$, sex $(55 \%$ versus $57 \%)$ and family history of CRC ( $11 \%$ versus $9 \%$ ) between patients without and patients with one or more $K$-ras oncogene mutations in the tumour (table 1).

For ten patients, two different mutations were observed in exon 1. In six of these patients, both mutations were found in codon 12, and the other four patients showed one mutation in codon 12 or codon 13 and one mutation in another codon. In eighteen patients without aberrations in codon 12 or codon 13, a mutation was found in codons $8,9,10,15$, 16,20 or 25.

Table 2 summarises the frequencies of genetic aberrations by type of mutation, affected codons and corresponding amino acids in the exon 1 fragment of the $K$-ras oncogene. The most frequently observed mutations in the gene are $\mathrm{G}>\mathrm{A}$ transitions, $\mathrm{G}>\mathrm{T}$ transversions and G>C transversions, i.e. $55 \%$ (155/281 mutations), $32 \%(90 / 281$ mutations) and $9 \%(24 / 281$ mutations), respectively. Of the total number of mutations in the exon 1 fragment, $72 \%$ (201/281) was observed in codon 12 (GGT) and 22\% (62/281) in codon 13 (GGC). In codon 12, the GAT codon (37\%) leading to aspartic acid and the GTT codon (35\%) leading to valine were the most frequently observed (table 2 ). In codon 13, the $G>A$ transition at the second base, which would lead to substitution of a glycine by aspartic acid, was by far the predominant mutation (94\%). Furthermore, the point mutations (17/281) observed in codons $8,10,15,16,19,20$ and 25 were all transitions. In one case, an insertion of 6 nucleotides was observed in codon 9 , leading to one altered codon and two inserted codons, however, 
without a frameshift in the gene (table 2). The only alteration in the protein is the insertion of two extra amino acids.

\section{Tumour Sublocalisation}

Patients with rectal tumours have relatively the highest frequency of $K$-ras mutations as compared to patients with proximal or distal colon tumours or patients with a rectosigmoid tumour ( $42 \%$ versus $38 \%, 30 \%$ and $40 \%$, respectively; $p=0.09$ ) (table 3 ). Moreover, different tumour sublocalisations showed different frequencies of $\mathrm{G}>\mathrm{T}$ transversions as well as different frequencies of codon 12 or codon 13 mutations. Patients with a rectal tumour have the highest frequency of $\mathrm{G}>\mathrm{T}$ transversions ( $16 \%$ versus $11 \%, 9 \%$ and $14 \%$ for proximal, distal and rectosigmoid tumours, respectively; $\mathrm{p}=0.22)$ and codon 12 mutations $(34 \%$ versus $25 \%, 22 \%$ and $25 \%$, respectively; $p=0.07$ ) (table 3 ). It should be noted that most $G>T$ transversions are confined to codon 12 (table 2). Patients with a tumour in the rectosigmoid, however, have the highest frequency of codon 13 mutations ( $14 \%$ versus $11 \%, 5 \%$ and $6 \%$ for proximal, distal and rectal tumour, respectively; $p=0.03$ ) (table 3 ). Stratification by sex, in addition, reveals that women with a rectal tumour have the highest prevalence of $K$-ras mutations (53\% versus $37 \%, 23 \%$ and $37 \%$ for proximal, distal and rectosigmoid tumour, respectively; $\mathrm{p}=0.001$ ). This difference was confined, in particular, to the $\mathrm{G}>\mathrm{T}$ transversions ( $27 \%$ for rectal tumour versus $8 \%, 11 \%$ and $7 \%$ for proximal and distal colon tumour and rectosigmoid tumour, respectively; $p=0.002$ ) (table 4).

Table 4 Stratification by sex with respect to tumour sublocalisation

\begin{tabular}{|c|c|c|c|c|c|c|}
\hline & & $\begin{array}{l}\text { Wild type } \\
\text { K-ras }\end{array}$ & $\begin{array}{l}\text { K-ras } \\
\text { mutatione }\end{array}$ & $\begin{array}{l}\text { G>A } \\
\text { transition }\end{array}$ & $\begin{array}{l}\text { G>T } \\
\text { transversione }\end{array}$ & $\begin{array}{l}\mathrm{G}>\mathrm{C} \\
\text { transversion }\end{array}$ \\
\hline \multirow[t]{7}{*}{ Men } & & & & & & \\
\hline & Sublocalisation* & 252 & 151 & 87 & 47 & 11 \\
\hline & Proximal colon & $71(61 \%)$ & $45(39 \%)$ & $25(22 \%)$ & $17(15 \%)$ & $0(0 \%)$ \\
\hline & Distal colon & $84(64 \%)$ & $47(36 \%)$ & $27(21 \%)$ & $10(8 \%)$ & $6(5 \%)$ \\
\hline & Rectosiamoid & $25(57 \%)$ & $19(43 \%)$ & $9(20 \%)$ & $9(21 \%)$ & $1(2 \%)$ \\
\hline & Rectum & $72(64 \%)$ & $40(36 \%)$ & $24(21 \%)$ & $11(9 \%)$ & $5(4 \%)$ \\
\hline & p-value & & 0.77 & 0.99 & 0.07 & 0.13 \\
\hline \multirow{6}{*}{ Women } & Sublocalisation" & 206 & 116 & 66 & 40 & 12 \\
\hline & Proximal colon & $78(63 \%)$ & $46(37 \%)$ & $30(24 \%)$ & $10(8 \%)$ & $7(6 \%)$ \\
\hline & Distal colon & $72(77 \%)$ & $21(23 \%)$ & $11(12 \%)$ & $10(11 \%)$ & $0(0 \%)$ \\
\hline & Rectosigmoid & $26(63 \%)$ & $15(37 \%)$ & $11(27 \%)$ & $3(7 \%)$ & $1(2 \%)$ \\
\hline & Rectum & $30(47 \%)$ & $34(53 \%)$ & $13(20 \%)$ & $17(27 \%)$ & $4(6 \%)$ \\
\hline & p-value & & 0.001 & 0.09 & 0.002 & 0.10 \\
\hline
\end{tabular}

\footnotetext{
- For 5 male patients and 3 female patients without a $K$-ras mutation and 2 male patients and 2 female patients with at least one mutation, the site of localisation in the colon could not be determined (colon, NOS)

b comparisons between patients without a $K$-ras mutation and patients with at least one $K$-ras mutation, patients with at least one $G>A$ transition, $G>T$ or $G>C$ transversion

"The frequencies of $G>A$ transition, $G>T$ or $G>C$ transversion per sublocalisation and sex was calculated by dividing the number of patients with $\mathrm{G}>\mathrm{A}$ transitions (for example) through the total number of CRC patients
}

We also evaluated the $K$-ras mutational status for tumours in the proximal and distal colon and for tumours in the colon versus the rectum (tumours in the rectosigmoid were excluded for this analysis). It was found that patients with a proximal colon tumour had a higher frequency of $G>A$ transitions as compared to patients with a distal colon tumour $(p=0.11)$ (table 3). This difference in frequencies of $\mathrm{G}>\mathrm{A}$ transitions with respect to proximal and distal colon tumours was more pronounced for women $(p=0.02)$ (table 4). Patients with a rectal tumour showed a relatively higher frequency of $K$-ras mutations $(p=0.08)$, and in particular $G>T$ transversions $(p=0.06)$, as compared to patients with a colon tumour. Again, this difference was due to the high frequency of $\mathrm{G}>\mathrm{T}$ transversions in rectal tumours observed in women $(p=0.0003)$ (table 4). 


\section{Dukes' Stage}

Most tumours were staged as Dukes' B (35\%, 238/685), and tumours with Dukes' D stage $(12 \%, 85 / 685)$ constitute the smallest group (table 3$)$. Patients with a Dukes' A staged tumour more often have G>A transitions ( $26 \%$ versus $16 \%, 20 \%$ and $19 \%$ for Dukes' B, C and $D$, respectively; $p=0.13$ ), whereas patients with a Dukes' $D$ staged tumour have relatively a higher frequency of G>T transversions ( $18 \%$ versus $8 \%, 15 \%$ and $9 \%$ for Dukes' A, B or C, respectively; $p=0.04$ ). No clear differences were observed in the frequencies of codon 12 or codon 13 mutations with respect to the Dukes' stage of the tumour (table 3).

\section{Tumour Differentiation}

No differences were observed in frequencies of $K$-ras mutations, G>A transitions, G>T or $G>C$ transversions or mutations in codon 12 or codon $13(p>0.05)$ with respect to tumour differentiation.

\section{DISCUSSION}

Overall, we observed that the frequency of $K$-ras oncogene mutations in a large representative sample of CRC patients from The Netherlands (age at diagnosis between 57 and 76 years) was $37 \%$. The frequency of $K$-ras gene mutations in CRC patients reported in the literature, ranges from $30-60 \%(3,9,11,12,16-27)$. This broad range of reported frequencies of $K$-ras mutations may be due to various factors, such as the sensitivity and specificity of mutation detection methods, small series of, selected, patients $(3,12,17,20,21,23)$ and/or variability in analysed gene region, i.e. only codons $12(21), 13$ $(12,20,22,23,28)$ and/or 61 (11). Also, environmental factors may be involved. Techniques used for mutation screening such as temperature gradient gel electrophoresis (TGGE) (3) or SSCP $(17,29)$ and methods for mutation detection like PCR-restriction fragment length polymorphism (RFLP) $(20,28)$ or PCR-based mutant allele-specific amplification (MASA) (20) may show differences in sensitivity and/or specificity of mutation detection in the K-ras gene. In this study, the analysis of K-ras mutations is based on a highly sensitive and specific detection method, i.e. direct sequencing of purified PCR fragments. This method identifies mutations in DNA samples which contain at least five percent or more mutated DNA. The reported frequency of $K$-ras mutations could, therefore, be an underestimation. Direct sequencing was validated by mutation analysis of five CRC cell lines, and of adjacent blocks with paraffin-embedded and fresh tissue from a series of $10 \mathrm{CRC}$ specimens. The mutation analysis of five CRC cell lines confirmed the reported sequences of exon 1 fragments of the K-ras oncogene (30). In addition, the K-ras mutation status as determined in paraffin-embedded tumour tissue was also found in fresh tumour tissue in 9 out of 10 specimens. In one specimen, the mutation detected in paraffin-embedded tissue was not found in fresh tissue which may be related to heterogeneity in the tumour tissue or a lack in the reproducibility of this sample. These results indicate that tissue processing does not significantly affect the reliability of mutation analysis in archival specimens. The reproducibility of the identification technique used in this study was found to be good, since duplication of the complete analytical procedure yielded the same results for 28 out of 32 $(88 \%)$ adenocarcinomas. The $K$-ras gene mutation analysis is based on a relatively large series of non-selected, incident CRC patients, which indicates that the found frequency of $K$-ras mutations is representative for CRC patients in the Dutch population.

Slattery et al (31) have evaluated the association between several genetic alterations and the presence or absence of family history of colorectal cancer using incident colon cancer cases. These authors did not find an association with overall $K$-ras mutations, although patients with a $\mathrm{G}>\mathrm{T}$ transversion of the second base of codon 12 were more likely 
to have a family history of colorectal cancer compared to those without this specific type of point mutation. In our study, no significant differences were observed in family history of CRC between patients without and with a $K$-ras mutation. Our findings suggest that these genetic alterations in sporadic colorectal tumours are not associated with family history of CRC and that therefore diet, environment and/or lifestyle factors may contribute to the acquirement of $\mathrm{K}$-ras gene mutations involved in the early phases of carcinogenesis. However, more studies evaluating other genetic markers and/or a different kind of population study, i.e twin studies, may be necessary to address this issue.

Studies from various countries have analysed the frequency of the type of $K$-ras point mutation in colorectal cancer. These studies were conducted in the UK $(24,25)$, former Yugoslavia (12), Czech Republic (21), Norway (9), Switserland (18), Mexico (11), USA (26) and The Netherlands $(17,19,20)$. All studies, except for the study performed in former Yugoslavia (12), have identified the $G>A$ transition as the most frequently found type of $K$ ras mutation. In the current study, the $G>A$ transition appeared also to be the predominant mutation. The pattern of specific alterations observed, i.e. G>A transitions and G>T transversions, could be due to differences in diet and/or other lifestyle factors. $\mathrm{N}$-nitroso compounds, for example, in red and processed meat could induce G>A transitions (25) and this is supported by previous experimental studies $(32,33)$. Two mechanisms, which could explain the G>A transition are the formation of guanine-adducts in the DNA and the silencing of the $\mathrm{O}^{6}$-methylguanine DNA methyltransferase (MGMT). MGMT is a DNA repair protein that removes adducts from the $\mathrm{O}^{6}$-position of guanine (34) in DNA. Promotor hypermethylation of the MGMT gene, a phenomenon often seen in colon cancer cells $(28,35)$ and which leads to silencing of the gene, results in conversions of guanine-cytosine pairs to adenine-thymine pairs. Guanine-to-thymine transversions, however, are more likely to be induced by carcinogenic agents like the polycyclic aromatic hydrocarbons (PAHs) found in smoked and barbecued meat (36), dietary fats (37) and cigarette smoke (38).

In the present study, codons 12 and 13 were affected in $94 \%$ of the tumours with a $K$-ras mutation in the exon 1 fragment, and the majority of mutations would result in an amino acid substitution of glycine by aspartic acid $(57 \%)$ or by valine $(33 \%)$. Mutations in either of these codons could lead to an activated Ras protein. Al-Mulla et al (39) compared detailed crystal structures of the Ras protein with these two most frequently observed mutations in codon 12, i.e. substitutions of glycine by aspartic-acid or valine. The tightly bound complex of GTP in codon 12 glycine-to-valine mutant Ras protein may generate a more stable signal as compared to the codon 12 glycine-to-aspartic acid mutant Ras protein or the codon 12 wild type Ras protein. Moreover, Andreyev et al (27) have shown that the presence of the glycine to valine substitution in codon 12 leads to a decreased survival of CRC patients and suggest this alteration is important for cancer progression and also that it may predispose to a more aggressive biological behaviour in patients with advanced CRC. Span et al (19) also observed an association between specific K-ras point mutations and cancer progression. Recently, Bazan et al (40) reported biological relevance for codon 13 mutations in terms of colorectal cancer clinical outcome, such as Dukes' stage $(p<0.05)$. They also reported a possible role for codon 12 mutations in the mucinous differentiation pathway. Associations between specific $K$-ras point mutations and cancer progression were, however, not supported by our and other studies $(3,26,41)$.

Eighteen patients were observed with an affected codon other than codons 12 or 13 . It is unknown whether mutations in these codons lead to a constituent activation of the Ras protein. Our results show that mutations in codons other than codons 12 or 13 of exon 1 are rare. The observed pattern of mutated codons, i.e. $94 \%$ of the mutations were found in codons 12 and 13, is probably due to a selective growth advantage (42).

Previous studies have presented frequencies of $K$-ras mutations based on tissue samples of selected series of patients with various distributions of Dukes' staged tumours. 
Some suggested an increase in the frequencies of the $K$-ras oncogene mutations with more advanced stages of Dukes' classification $(12,17)$, whereas others $(3,9,42)$ did not find any association between frequencies of point mutations and Dukes' stage. In the current study, all incident CRC cases were included regardless of the Dukes' stage. No significant differences in the distribution of Dukes' stage were observed between patients without a $K$-ras mutation and those with a specific $K$-ras gene mutation. It suggests that $K$-ras mutations are not involved in the progression of adenocarcinomas and that genetic aberrations occur in pathways, which do not depend on $K$-ras mutations during the more advanced stages of colorectal cancer.

Various topographical subdivisions of the large intestine have been proposed, according to different criteria $(22,43,44,45)$. The so-called rectosigmoid can be considered as a rather more clinically applied term than an anatomically defined transitional zone between the colon and rectum. Although the rectum is considered to comprise the last 12 $\mathrm{cm}$ of the intestine proximal of the anal verge, clinicopathological data are inconsistent as to whether the tumours in this region can be assigned to the colon or rectum (46). In our study, the NCR database contains the clinicopathological data, including the sublocalisation of the tumour, as supplied by the clinicians. Therefore, in the current multicenter study, for socalled rectosigmoid tumours it was not possible to definitively assign a tumour to either the colon or rectum. Consequently, the rectosigmoid was excluded from analysis when comparing colonic versus rectal adenocarcinomas. Among similar lines, another topographical issue which we addressed was the comparison of proximal versus distal colon tumours. Differences could be expected between these two with respect to faecal content and composition, microbial flora and activity, and the local variations in distribution of intestinal epithelial cell types. Owing to the mentioned unclear definition of the term rectosigmoid tumour, analyses were performed with both the ex- and inclusion of rectosigmoid tumours within the group of distal colon tumours. The resulting asymmetry between proximal and distal colon tumours was maintained, regardless of these differences in type of analysis.

Patients with a rectal tumour have a relatively higher frequency of $G>T$ transversions as compared to patients with a distal colon tumour and this difference appeared to be most pronounced for female patients. This was not found in other studies $(3,21,26,44)$. However, Breivik et al (9) reported that $K$-ras mutations were not found in tumours located proximal to the descending colon of men under the age of 70 , whereas rare mutations such as $\mathrm{G}>\mathrm{C}$ transversions were almost exclusively observed in tumours of the rectum of women. Again, results based on a smaller number of samples ( 123 men and 125 women, stratified by age) could lead to biased, inconsistent associations. In the current study, $\mathrm{G}>\mathrm{C}$ transversions also constitute a small group of specific point mutations, but were mainly observed in men with tumours in the distal colon and in women with tumours in the proximal colon. Plausible explanations for differences in tumour site could be the role of diet with respect to bowel transit time and bacterial fermentation of carbohydrates (47), production of volatile fatty acids (9) or exposure of colonic epithelium to potential dietary carcinogens (48). The relatively high frequency of $\mathrm{G}>\mathrm{T}$ transversions in the rectum of women might be related to sex differences in faecal concentration and transit time. Both bowel transit time and frequency of constipation have been reported to be substantially higher in women than in men under similar conditions (49). The $\mathrm{G}>\mathrm{T}$ transversions and also the generally higher frequency of $K$-ras mutations in women might be related to the time of contact with, and the concentration of, particular carcinogens. More aetiological insight in the underlying mechanisms is required to clarify this issue.

The $K$-ras mutational status was evaluated for differences in frequencies with respect to tumour differentiation. Most tumours were classified as 'moderately' differentiated. Generally, the distinction between good or moderately differentiated tumours is often 
ambiguous. Therefore, the classification of tumour differentiation could be biased. Our findings do not support a role of the $K$-ras oncogene in tumour differentiation.

In conclusion, we observed a frequency of $37 \%$ for mutations in exon 1 fragment of the $K$-ras oncogene, predominantly in codons 12 and 13 . The $G>A$ transition and the $G>T$ transversion are the most frequently observed mutations, with the $G>T$ transversion primarily confined to codon 12 . Patients with a rectal tumour have a relatively higher frequency of $\mathrm{G}>\mathrm{T}$ transversion as compared to patients with distal colon tumour and this is confined to female patients. The pattern of $K$-ras point mutations observed in the several sublocalisations of the colorectal tract is suggestive for the involvement of dietary factors.

\section{REFERENCES}

1. Kinzler KW and Vogelstein B. (1996) Lessons from hereditary colorectal cancer. Cell, 87, 159-70.

2. Shields JM, Pruitt K, McFall A, Shaub A and Der CJ. (2000) Understanding ras: 'it ain't over 'til it's over' [In Process Citation]. Trends Cell Biol, 10, 147-54.

3. Kressner U, Bjorheim J, Westring S, Wahlberg SS, Pahlman L, Glimelius B, Lindmark G, Lindblom A and Borresen-Dale AL. (1998) K-ras mutations and prognosis in colorectal cancer. Eur J Cancer, 34, 518-21.

4. Bos JL. (1989) ras oncogenes in human cancer: a review [published erratum appears in Cancer Res 1990 Feb 15;50(4):1352]. Cancer Res, 49, 4682-9.

5. Fearon ER and Vogelstein B. (1990) A genetic model for colorectal tumourigenesis. Cell, 61, 759-67.

6. Campbell SL, Khosravi-Far R, Rossman KL, Clark GJ and Der CJ. (1998) Increasing complexity of Ras signaling. Oncogene, 17, 1395-413.

7. Crespo P and Leon J. (2000) Ras proteins in the control of the cell cycle and cell differentiation. Cell Mol Life Sci, 57, 1613-36.

8. Kislitsin D, Lerner A, Rennert G and Lev Z. (2002) K-ras mutations in sporadic colorectal tumours in Israel: unusual high frequency of codon 13 mutations and evidence for nonhomogeneous representation of mutation subtypes. Dig Dis Sci, 47, 1073-9.

9. Breivik J, Meling GI, Spurkland A, Rognum TO and Gaudernack G. (1994) K-ras mutation in colorectal cancer: relations to patient age, sex and tumour location. $\mathrm{Br} J$ Cancer, 69, 367-71.

10. Vogelstein B, Fearon ER, Hamilton SR, Kern SE, Preisinger AC, Leppert M, Nakamura Y, White R, Smits AM and Bos JL. (1988) Genetic alterations during colorectal-tumour development. N Engl J Med, 319, 525-32.

11. Martinez-Garza SG, Nunez-Salazar A, Calderon-Garciduenas AL, Bosques-Padilla FJ, Niderhauser-Garcia A and Barrera-Saldana HA. (1999) Frequency and clinicopathology associations of $\mathrm{K}$-ras mutations in colorectal cancer in a northeast Mexican population. Dig Dis, 17, 225-9.

12. Urosevic N, Krtolica K, Skaro-Milic A, Knezevic-Usaj S and Dujic A. (1993) Prevalence of G-to-T transversions among K-ras oncogene mutations in human colorectal tumours in Yugoslavia. Int J Cancer, 54, 249-54.

13. Baisse B, Bouzourene H, Saraga EP, Bosman FT and Benhattar J. (2001) Intratumour genetic heterogeneity in advanced human colorectal adenocarcinoma. Int $J$ Cancer, 93, 346-52.

14. van den Brandt PA, Goldbohm RA, van 't Veer P, Volovics A, Hermus RJ and Sturmans F. (1990) A large-scale prospective cohort study on diet and cancer in The Netherlands. $J$ Clin Epidemiol, 43, 285-95. 
15. van den Brandt, PA, Schouten LJ, Goldbohm RA, Dorant E and Hunen PM. (1990) Development of a record linkage protocol for use in the Dutch Cancer Registry for Epidemiological Research. Int J Epidemiol, 19, 553-8.

16. Saraga E, Bautista D, Dorta G, Chaubert P, Martin P. Sordat B, Protiva P, Blum A, Bosman F and Benhattar J. (1997) Genetic heterogeneity in sporadic colorectal adenomas. J Pathol, 181, 281-6.

17. Moerkerk P. Arends JW, van Driel M, de Bruīne AP, de Goeij A and ten Kate J. (1994) Type and number of $K$-ras point mutations relate to stage of human colorectal cancer. Cancer Res, 54, 3376-8.

18. Cerottini JP, Caplin S, Saraga E, Givel JC and Benhattar J. (1998) The type of K-ras mutation determines prognosis in colorectal cancer. Am J Surg, 175, 198-202.

19. Span M, Moerkerk PT, De Goeij AF and Arends JW. (1996) A detailed analysis of $K$-ras point mutations in relation to tumour progression and survival in colorectal cancer patients. Int J Cancer, 69, 241-5.

20. Kampman E, Voskuil DW, van Kraats AA, Balder HF, van Muijen GN, Goldbohm RA and van 't Veer P. (2000) Animal products and $K$-ras codon 12 and 13 mutations in colon carcinomas. Carcinogenesis, 21, 307-9.

21. Beranek M, Bures J, Palicka V, Jandik P, Langr F and Nejedla E. (1999) A relationship between $K$-ras gene mutations and some clinical and histologic variables in patients with primary colorectal carcinoma. Clin Chem Lab Med, 37, 723-7.

22. Capella G, Cronauer-Mitra S, Pienado MA and Perucho M. (1991) Frequency and spectrum of mutations at codons 12 and 13 of the c-K-ras gene in human tumours. Environ Health Perspect, 93, 125-31.

23. Guan RJ, Fu Y, Holt PR and Pardee AB. (1999) Association of K-ras mutations with p16 methylation in human colon cancer. Gastroenterology, 116, 1063-71.

24. Hughes R, Cross AJ, Pollock JR and Bingham S. (2001) Dose-dependent effect of dietary meat on endogenous colonic $\mathrm{N}$ - nitrosation. Carcinogenesis, 22, 199-202.

25. Bingham SA, Pignatelli B, Pollock JR, Ellul A, Malaveille C, Gross G, Runswick S, Cummings JH and O'Neill IK. (1996) Does increased endogenous formation of Nnitroso compounds in the human colon explain the association between red meat and colon cancer? Carcinogenesis, 17, 515-23.

26. Samowitz WS, Curtin K, Schaffer D, Robertson M, Leppert M and Slattery ML. (2000) Relationship of $K$-ras mutations in colon cancers to tumour location, stage, and survival: a population-based study. Cancer Epidemiol Biomarkers Prev, 9, 1193-7.

27. Andreyev HJ, Norman AR, Cunningham D, Oates J, Dix BR, lacopetta BJ, Young J, Walsh T, Ward R, Hawkins N, Beranek M, Jandik P, Benamouzig R, Jullian E, LaurentPuig P, Olschwang S, Muller O, Hoffmann I, Rabes HM, Zietz C, Troungos C, Valavanis C, Yuen ST, Ho JW, Croke CT, O'Donoghue DP, Giaretti W, Rapallo A, Russo A, Bazan V, Tanaka M, Omura K, Azuma T, Ohkusa T, Fujimori T, Ono Y, Pauly M, Faber C, Glaesener R, de Goeij AF, Arends JW, Andersen SN, Lovig T, Breivik J, Gaudernack G, Clausen OP, De Angelis PD, Meling GI, Rognum TO, Smith R, Goh HS, Font A, Rosell R, Sun XF, Zhang H, Benhattar J, Losi L, Lee JQ, Wang ST, Clarke PA, Bell S, Quirke P, Bubb VJ, Piris J, Cruickshank NR, Morton D, Fox JC, Al-Mulla F, Lees N, Hall CN, Snary D, Wilkinson K, Dillon D, Costa J, Pricolo VE, Finkelstein SD, Thebo JS, Senagore AJ, Halter SA, Wadler S, Malik S, Krtolica K and Urosevic N. (2001) Kirsten ras mutations in patients with colorectal cancer: the 'RASCAL II' study. Br J Cancer, 85 , 692-6.

28. Esteller M, Toyota M, Sanchez-Cespedes M, Capella G, Peinado MA, Watkins DN, Issa JP, Sidransky D, Baylin SB and Herman JG. (2000) Inactivation of the DNA repair gene O6-methylguanine-DNA methyltransferase by promoter hypermethylation is associated with $\mathrm{G}$ to $\mathrm{A}$ mutations in $\mathrm{K}$-ras in colorectal tumourigenesis. Cancer Res, 60, 2368-71. 
29. Luna-Perez P, Segura J, Alvarado I, Labastida S, Santiago-Payan H and Quintero A. (2000) Specific c-K-ras gene mutations as a tumour-response marker in locally advanced rectal cancer treated with preoperative chemoradiotherapy. Ann Surg Oncol, 7, 727-31.

30. Poncin J, Mulkens J, Arends JW and de Goeij A. (1999) Optimizing the APC gene mutation analysis in archival colorectal tumour tissue [In Process Citation]. Diagn Mol Pathol, 8, 11-9.

31. Slattery ML, Curtin K, Schaffer D, Anderson K and Samowitz W. (2002) Associations between family history of colorectal cancer and genetic alterations in tumours. Int $J$ Cancer, 97, 823-7.

32. Topal MD. (1988) DNA repair, oncogenes and carcinogenesis. Carcinogenesis, 9, 6916.

33. Zarbl H, Sukumar S, Arthur AV, Martin-Zanca D and Barbacid M. (1985) Direct mutagenesis of Ha-ras-1 oncogenes by $\mathrm{N}$-nitroso- $\mathrm{N}$-methylurea during initiation of mammary carcinogenesis in rats. Nature, 315, 382-5.

34. Toft NJ and Arends MJ. (1998) DNA mismatch repair and colorectal cancer. J Pathol, 185, 123-9.

35. Martinez ME, Maltzman T, Marshall JR, Einspahr J, Reid ME, Sampliner R, Ahnen DJ, Hamilton SR and Alberts DS. (1999) Risk factors for K-ras protooncogene mutation in sporadic colorectal adenomas. Cancer Res, 59, 5181-5.

36. Stevens CW, Manoharan TH and Fahl WE. (1988) Characterization of mutagenactivated cellular oncogenes that confer anchorage independence to human fibroblasts and tumourigenicity to NIH 3T3 cells: sequence analysis of an enzymatically amplified mutant HRAS allele. Proc Natl Acad Sci U S A, 85, 3875-9.

37. Slattery ML, Curtin K, Anderson K, Ma KN, Edwards S, Leppert M, Potter J, Schaffer D and Samowitz WS. (2000) Associations between dietary intake and $K$-ras mutations in colon tumours: a population-based study. Cancer Res, 60, 6935-41.

38. Potter JD. (1999) Colorectal cancer: molecules and populations. J Natl Cancer Inst, 91, 916-32.

39. Al-Mulla F, Milner-White EJ, Going JJ and Birnie GD. (1999) Structural differences between valine-12 and aspartate-12 Ras proteins may modify carcinoma aggression. $J$ Pathol, 187, 433-8.

40. Bazan V, Migliavacca M, Zanna I, Tubiolo C, Grassi N, Latteri MA, La Farina M, Albanese I, Dardanoni G, Salerno S, Tomasino RM, Labianca R, Gebbia N and Russo A. (2002) Specific codon $13 \mathrm{~K}$-ras mutations are predictive of clinical outcome in colorectal cancer patients, whereas codon $12 \mathrm{~K}$-ras mutations are associated with mucinous histotype. Ann Oncol, 13, 1438-46.

41. Bouzourene H, Gervaz P, Cerottini JP, Benhattar J, Chaubert P, Saraga E, Pampallona S, Bosman FT and Givel JC. (2000) p53 and K-ras as prognostic factors for Dukes' stage B colorectal cancer. Eur J Cancer, 36, 1008-15.

42. Bos JL, Fearon ER, Hamilton SR, Verlaan-de Vries M, van Boom JH, van der Eb AJ and Vogelstein B. (1987) Prevalence of ras gene mutations in human colorectal cancers. Nature, 327, 293-7.

43. Al-Mulla F, Going JJ, Sowden ET, Winter A, Pickford IR and Birnie GD. (1998) Heterogeneity of mutant versus wild-type $K$-ras in primary and metastatic colorectal carcinomas, and association of codon-12 valine with early mortality. J Pathol, 185, 1308.

44. O'Brien H, Matthew JA, Gee JM, Watson M, Rhodes M, Speakman CT, Stebbings WS, Kennedy HJ and Johnson IT. (2000) K-ras mutations, rectal crypt cells proliferation, and meat consumption in patients with left-sided colorectal carcinoma. Eur J Cancer Prev, 9, 41-7. 
45. Slattery ML, Anderson K, Curtin K, Ma K, Schaffer D, Edwards S and Samowitz W. (2001) Lifestyle factors and K-ras mutations in colon cancer tumours. Mutat Res, 483, 73-81.

46. Schouten LJ, Jager JJ and van den Brandt PA. (1993) Quality of cancer registry data: a comparison of data provided by clinicians with those of registration personnel. $\mathrm{Br} J$ Cancer, 68, 974-7.

47. Topping DL and Clifton PM. (2001) Short-chain fatty acids and human colonic function: roles of resistant starch and nonstarch polysaccharides. Physiol Rev, 81, 1031-64.

48. Sugimura T. (2000) Nutrition and dietary carcinogens. Carcinogenesis, 21, 387-395.

49. Lampe JW, Fredstrom SB, Slavin JL and Potter JD. (1993) Sex differences in colonic function: a randomised trial. Gut, 34, 531-6. 


\section{Meat consumption and $K$-ras mutations in sporadic colon and rectal cancer in The Netherlands Cohort Study}




\title{
Meat consumption and $K$-ras mutations in sporadic colon and rectal cancer in The Netherlands Cohort Study
}

\author{
Mirian Brink ${ }^{1}$ \\ Matty P Weijenberg ${ }^{1}$ \\ Anton FPM de Goeij ${ }^{2}$ \\ Guido MJM Roemen $^{3}$ \\ Marjolein HFM Lentjes ${ }^{3}$ \\ Adriaan $\mathrm{P}$ de Bruinne ${ }^{2}$ \\ R Alexandra Goldbohm ${ }^{4}$ \\ Piet $A$ van den Brandt ${ }^{1}$
}

' Nutrition and Toxicology Research Institute Maastricht (NUTRIM), Dept. of Epidemiology,

Maastricht University, Maastricht, The Netherlands

${ }^{2}$ Research Institute Growth and Development (GROW), Dept. of Pathology, Maastricht University, The Netherlands

${ }^{3}$ NUTRIM, Dept. of Pathology, Maastricht University, The Netherlands

${ }^{4}$ TNO Nutrition and Food Research, Zeist, The Netherlands 


\begin{abstract}
Associations between meat and fish consumption and $K$-ras mutations in colon and rectal cancer were investigated in The Netherlands Cohort Study on diet and cancer.

After 7.3 years of follow-up, excluding the first 2.3 years, 448 colon and 160 rectal cancer patients, and 2948 subcohort members were available for data-analyses. $K$-ras gene mutation analysis was performed on all archival adenocarcinomas. Case-cohort analyses were used to compute adjusted incidence rate ratios (RR) and $95 \%$ confidence intervals $(\mathrm{Cl})$ for colon and rectal cancer and for $K$-ras mutation status subgroups.

Total fresh meat, most types of fresh meat and fish were not associated with colon or rectal cancer, neither overall nor with $K$-ras mutation status. However, several weak associations were observed for wild type $K$-ras, i.e. an increased association for beef and colon tumours, and an inverse association for pork and colon and rectal tumours. For meat products, an increased association was observed with wild type $K$-ras tumours in the colon.

Although neither total fresh meat nor fish appeared to be associated with colon or rectal cancer risk, beef, pork and meat products are differentially associated with colon and rectal cancer risk, depending on $K$-ras mutation status.
\end{abstract}




\section{INTRODUCTION}

The current epidemiological evidence for associations of different types of meat, meat products and fish with colorectal cancer (CRC) risk is controversial (1-3). These observed inconsistencies could, in part, be due to the heterogeneity of the colon and rectal cancer endpoint that is studied. Associations may become more apparent when the molecular events involved in colorectal carcinogenesis are taken into account.

The majority of colon and rectal tumours develops from small adenomatous polyps through a well-defined sequence of morphological changes (4), a process that is associated with the acquisition of somatic mutations $(5,6)$. A genetic alteration that occurs in adenomas $(10 \%)$ as well as in carcinomas $(40 \%)$ of the colon and rectum, is the oncogenic activation of the $K$-ras gene by mutations. Activating mutations are mainly found in codons 12 and 13 $(5,7-9)$. The most frequently observed types of point mutations are the $G>A$ transitions, $G>T$ and $\mathrm{G}>\mathrm{C}$ transversions (9-11).

The link between several types of fresh meat, meat products and fish, and the pattern of $K$-ras mutations in human colon and rectal cancer is not clear. To date, only a few casecontrol and case-case studies have been conducted on the association between the consumption of dietary factors and $K$-ras mutation status (12-17). Four studies reported on several types of meat consumption $(12,14,15,17)$.

It has been suggested that $\mathrm{N}$-nitroso compounds, present in processed meat or endogenously formed (12), may induce G>A transitions at the second base of codon 12 or 13 of the $K$-ras gene in the human colon (13). High temperature cooking of meat proteins generates heterocyclic aromatic amines (HAA), whereas the process of grilling and smoking of meat generates polycyclic aromatic amines (PAH) as a result of fat dropping on open flames. HAA-DNA-adducts can cause transitions and transversions, whereas PAH's could induce $\mathrm{G}>\mathrm{T}$ transversions in the $K$-ras gene. Results from animal experiments, however, are not consistent (14).

Consequently, high consumption of meat and fish could contribute to the acquired genetic alterations in the $K$-ras oncogene observed in colon and rectal tumours. Therefore, associations between dietary consumption of different types of meat, meat products and fish, and the risk of specific point mutations in the $K$-ras oncogene in patients with colon and rectal cancer were studied within the framework of The Netherlands Cohort Study on diet and cancer (NLCS).

\section{MATERIALS AND METHODS}

\section{Study Population}

The study subjects are incident colon and rectal cancer cases and subcohort members from the NLCS, which has been described in detail elsewhere (15). Briefly, the cohort study was initiated in 1986 and includes 58,279 men and 62,573 women, aged 55-69 years old at baseline, who originated from 204 Dutch municipalities with computerized population registries. A self-administered questionnaire on diet and other risk factors for cancer was completed at baseline. The entire cohort is being monitored for cancer occurrence by annual record linkage to The Netherlands Cancer Registry (NCR, nine cancer registries in The Netherlands) and to PALGA, a nationwide network and registry of histo- and cytopathology (www.palga.nl) (16). In the municipalities included in the NLCS, the NCR and PALGA, together, have nearly $100 \%$ coverage since the start of the study (17-19). PALGA also provides necessary information on the identification of the pathology laboratory location of the storage of paraffin-embedded blocks of the eligible CRC patients. Accumulation of 
person-time in the cohort has been estimated through biennial vital status follow-up of a subcohort of 3,500 men and women who were randomly selected after baseline exposure measurement. Cases with prevalent cancer other than non-melanoma skin cancer were excluded from the subcohort, which left 3,346 men and women for analyses.

The first 2.3 years of follow-up were excluded due to incomplete coverage of PALGA alone in some of the municipalities included in the NLCS. Within this period, 83 subcohort members were either deceased or diagnosed with cancer other than non-melanoma skin cancer, leaving 3,263 men and women for analysis. From 1989 till 1994, 929 incident cases with histologically confirmed CRC were observed of whom 819 could also be linked to a PALGA report of the lesion. The PALGA database was used to identify and locate tumour tissue in Dutch pathology laboratories. CRC was classified according to site as follows: colon i.e. cecum through sigmoid colon (ICD-O-1 codes: 153.0, 153.1, 153.2, 153.3, 153.4, 153.5, 153.6, 153.7, 153.8, 153.9), rectosigmoid (ICD-O-1 code 154.0) and rectum (ICD-O-1 code 154.1). Information about age at baseline, sex and family history of CRC (at baseline) was retrieved from the NLCS database.

\section{Tissue Samples}

This study is based on data of gene mutation analysis from CRC patients, described in detail elsewhere (9). Briefly, tumour material of all CRC patients was collected after approval by the Medical Ethics Committees of Maastricht University, the NCR and PALGA. Subsequently, all pathology laboratories in The Netherlands agreed to make relevant tissue samples available upon request from PALGA. Tissue samples of the 819 cases were distributed among 54 pathology laboratories throughout The Netherlands. Tumour tissue specimen collection started in August 1999 and was completed in December 2001. The loss to follow-up of tissue samples of cases amounted to $5 \%$. Tissue samples from nine patients registered in one pathology laboratory could not be retrieved due to administrative inconsistencies, leaving 810 tissue samples for collection. For 34 cases, paraffin-embedded material was not available in the archives of pathology laboratories, leaving 776 cases for the determination of the $K$-ras mutation status. For 39 cases $(5 \%)$, the $K$-ras mutation status could not be determined, i.e. for 20 cases only normal colonic mucosa was available, 10 cases were revised with an benign adenoma ( $\mathrm{ddB}$ ) instead of an adenocarcinoma, for six cases the yield of DNA was not sufficient to determine $K$-ras mutation status and for three cases the available tissue did not include malignant CRC tissue. Finally, tumour material from 737 incident colorectal adenocarcinoma cases was available of whom $\mathbf{4 7 6}$ were colon cancer cases, 85 were rectosigmoid cancer cases and 176 were rectal cancer cases. Statistical analyses were performed separately for colon and rectal cancer as differences in the aetiology of colon and rectal cancer have been reported (1). Since the rectosigmoid can be considered as a clinically applied term rather than an anatomically defined transitional zone between the colon and rectum, patients with a rectosigmoid tumour were excluded from data-analyses. Moreover, the number of patients with a rectosigmoid tumour was too small for adequate stratified analyses (9).

\section{Detection of $\boldsymbol{K}$-ras Mutations}

Mutation analysis of the exon 1 fragment of the $K$-ras oncogene, spanning codons 8-29, was performed on archival colorectal adenocarcinoma specimens of all 737 CRC patients using macrodissection, nested Polymerase Chain Reaction (PCR) and direct sequencing of purified fragments, which has been described in detail elsewhere (9). The method of mutation detection was validated by the confirmation of reported $K$-ras status in CRC cell lines and a good correlation between fresh-frozen and routinely-fixed, paraffin-embedded tissue. The detection limit was $5 \%$ mutated DNA. Duplicate analyses revealed a good 
reproducibility (88\%) (9). Two observers (GR and ML) independently performed evaluation of mutation analysis and data entry.

\section{The Food Frequency Questionnaire}

The dietary section of the questionnaire was a 150-item semi-quantitative food frequency questionnaire, which concentrated on habitual consumption of food and beverages during the year preceding the start of the study. Daily mean nutrient intakes were calculated using the computerized Dutch food composition table (20), by multiplying frequencies and portion sizes of all food items with their tabulated nutrient contents. The questionnaire was validated against a 9-day diet record (21). The Spearman correlation coefficients for total fresh meat, meat products and fish were $0.46,0.54$ and 0.53 , respectively (21). Questionnaire data were key-entered twice and processed for all incident cases in the cohort and for all subcohort members in a manner blinded with respect to case/subcohort status. This was done in order to minimise observer bias in coding and interpretation of the data.

For 257 subjects (28 incident colon adenocarcinoma cases, 16 incident rectal adenocarcinoma cases and 215 subcohort members; two subcohort members were also colon or rectal cancer cases), dietary data were incomplete or inconsistent, and they were excluded from the analyses. These subjects either 1) left 60 or more (out of 150) questionnaire items blank and ate fewer than 35 items at least once per month and/or 2) left one or more item blocks (groups of items, i.e., beverages) blank. Additional details are given elsewhere (21). Hence, 448 colon and 160 rectal cases and 3048 subcohort members were available for data-analyses.

The food frequency questionnaire contained 14 items on the consumption of meat with the main (hot) meal (mainly fresh meat, including chicken), 5 items on the consumption of meat products, which are used as sandwich filling, and 3 items on fish consumption. For the serving size of total fresh meat, a question was included on the quantity of meat usually purchased (per person, per meal). Fresh meat is defined as meat that has not undergone some form of preservation, i.e. smoking, fermentation, and/or treatment with nitrate and/or nitrite salt ("curing") and which includes beef, pork, minced meat, chicken, liver and other meat (i.e. sausages). Coding of fresh meat items was based on raw weight to take into account the amount of fat originally present in the meat but ultimately ending up into the gravy, which is usually consumed as well. Meat products are defined as meat items that have undergone some form of preservation (mostly cured, sometimes also smoked or fermented). For chicken and fish, standard serving sizes were used. Meat items included in the questionnaire were converted into mean daily consumption in grams.

Quartiles of the consumption of total fresh meat, beef, pork, liver, minced meat, other meat, and meat products were computed for men and women separately, based on the distribution of subcohort members as described in detail later. For chicken and fish, groups were classified into a non-user and three user categories (5.3-13.2, 13.2-22.8 and $\geq 22.8$ $\mathrm{g} /$ day for chicken and 0-10, 10-20 and $\geq 20 \mathrm{~g} /$ day for fish) and this classification was used for both men and women.

Daily intake of dietary fibre ( $g /$ day), alcohol ( $g /$ day), fruit ( $g /$ day), vegetables $(g /$ day) and total energy (kcal/day) and age at baseline (years), sex (men/women), Quetelet Index (Ql; $\mathrm{kg} / \mathrm{m}^{2}$ ), physical activity (<30 min/d, 30-60 min/d, 60-90 min/d, >90 $\mathrm{min} / \mathrm{d}$ ), family history of CRC (yes/no) and smoking status (never/ex/current) were regarded as potential confounders. 
Table 1 Meat variables and other characteristics (mean \pm SD) of the study population at baseline

\begin{tabular}{|c|c|c|c|}
\hline & Subcohort & & cancer \\
\hline & & Wild type K-ras & Mutated K-ras \\
\hline N & 3048 & 297 & 151 \\
\hline Sex ( $\%$ Men) & 48.4 & 51.5 & 58.9 \\
\hline Age $(y)$ & $61.4 \pm 4.2$ & $62.7 \pm 4.0$ & $63.8 \pm 4.1$ \\
\hline Meat variables & & & \\
\hline Total fresh meat (g/day) & $99.7 \pm 42.2$ & $98.4 \pm 37.0$ & $99.3 \pm 39.1$ \\
\hline Beef (g/day) & $25.7 \pm 22.5$ & $27.9 \pm 21.8$ & $27.6 \pm 23.6$ \\
\hline Pork (g/day) & $38.4 \pm 30.3$ & $36.3 \pm 30.1$ & $37.6 \pm 29.6$ \\
\hline Minced meat (g/day) & $18.3 \pm 17.3$ & $17.2 \pm 13.4$ & $18.0 \pm 16.0$ \\
\hline Liver (g/day) & $2.0 \pm 4.4$ & $1.9 \pm 4.2$ & $1.8 \pm 4.1$ \\
\hline Chicken (g/day) & $13.7 \pm 15.6$ & $13.2 \pm 15.5$ & $12.4 \pm 15.2$ \\
\hline Other meat (g/day) & $2.5 \pm 6.4$ & $2.9 \pm 8.0$ & $2.7 \pm 5.9$ \\
\hline Meat products (g/day) & $13.2 \pm 15.0$ & $15.0 \pm 16.6$ & $11.7 \pm 13.2$ \\
\hline Fish and shellfish (g/day) & $12.7 \pm 15.0$ & $11.4 \pm 13.5$ & $13.2 \pm 15.7$ \\
\hline Other dietary factors & & & \\
\hline Fiber (g/day) & $27.0 \pm 8.2$ & $26.7 \pm 7.6$ & $27.7 \pm 8.8$ \\
\hline Alcohol (g/day) & $10.1 \pm 14.1$ & $11.0 \pm 15.4$ & $10.8 \pm 14.2$ \\
\hline Fruit (g/day) & $176.3 \pm 117.7$ & $172.7 \pm 123.7$ & $176.9 \pm 122.2$ \\
\hline Vegetable (g/day) & $193.6 \pm 82.3$ & $183.3 \pm 78.2$ & $198.0 \pm 87.0$ \\
\hline Energy (kcal/day) & $1919.4 \pm 518.1$ & $1916.5 \pm 494.4$ & $1902.7 \pm 472.9$ \\
\hline Other characteristics & & & \\
\hline QI $\left(\mathrm{kg} / \mathrm{m}^{2}\right)$ & $25.1 \pm 3.1$ & $25.5 \pm 3.2$ & $25.8 \pm 3.3$ \\
\hline Family history of CRC (\% Yes) & 5.6 & 13.5 & 9.3 \\
\hline Smoker $(\%)$ & & & \\
\hline Never & 37.0 & 36.7 & 37.1 \\
\hline Ex smoker & 35.2 & 43.1 & 46.4 \\
\hline Current smoker & 27.8 & 20.2 & 16.6 \\
\hline Physical activity $(\%)^{*}$ & & & \\
\hline$<30$ minutes/day & 20.9 & 19.7 & 20.3 \\
\hline $30-60$ minutes/day & 32.7 & 33.7 & 32.4 \\
\hline $60-90$ minutes/day & 30.9 & 29.6 & 29.1 \\
\hline$>90$ minutes/day & 15.5 & 17.0 & 18.2 \\
\hline
\end{tabular}

\section{Statistical Analysis}

The overall frequency of $K$-ras mutations as well as the type of mutation were computed for all colon and rectal cancer cases as described elsewhere (9). Mean values of the continuous variables age at baseline (years), consumption of total fresh meat, beef, pork, minced meat, chicken, liver, other meat, meat products, fish, dietary fiber, alcohol, fruit, vegetables, total energy and QI were evaluated for subcohort members and colon and rectal cancer cases with wild type and mutated K-ras gene. Distributions of the categorical variables sex, family history of CRC, smoking status and physical activity were evaluated for subcohort members and colon and rectal cancer patients with wild type and mutated $K$-ras gene and tested for differences between patient groups with the $x^{2}$-test. Differences in mean values of the continuous variables between patients with wild type and mutated $K$-ras gene were tested with the Student T-test or the Mann-Whitney-U-test if the variables were not normally distributed. The statistical software package SPSS (version 9) was used for these analyses.

Incidence rate ratios (RR) and corresponding 95\% confidence intervals $(\mathrm{Cl})$ were estimated for colon and rectal cancer cases with wild type or mutated $K$-ras gene tumours. RRs were computed using Cox regression models with the STATA statistical software package (intercooled STATA, version 7) according to consumption of quartiles or 
Table 1 continued

\begin{tabular}{|c|c|c|c|}
\hline \multirow[b]{2}{*}{ p-value } & \multicolumn{2}{|c|}{ Rectal cancer } & \multirow[b]{2}{*}{ p-value } \\
\hline & Wild type K-ras & Mutated $K$-ras & \\
\hline $\begin{array}{l}0.14 \\
0.006\end{array}$ & $\begin{array}{l}93 \\
72.0 \\
62.6 \pm 4.1\end{array}$ & $\begin{array}{l}67 \\
55.2 \\
62.2 \pm 4.0\end{array}$ & $\begin{array}{l}0.03 \\
0.50\end{array}$ \\
\hline $\begin{array}{l}0.82 \\
0.90 \\
0.67 \\
0.57 \\
0.29 \\
0.55 \\
0.95 \\
0.02 \\
0.24\end{array}$ & $\begin{array}{l}100.6 \pm 40.3 \\
27.6 \pm 24.6 \\
32.2 \pm 27.0 \\
23.2 \pm 25.2 \\
2.1 \pm 4.1 \\
14.5 \pm 15.6 \\
2.2 \pm 4.1 \\
13.5 \pm 14.7 \\
12.4 \pm 13.1\end{array}$ & $\begin{array}{l}95.7 \pm 36.6 \\
22.5 \pm 23.3 \\
40.8 \pm 29.3 \\
16.7 \pm 12.4 \\
1.9 \pm 4.4 \\
12.3 \pm 12.8 \\
2.7 \pm 4.8 \\
15.0 \pm 12.9 \\
11.0 \pm 10.3\end{array}$ & $\begin{array}{l}0.43 \\
0.19 \\
0.06 \\
0.03 \\
0.90 \\
0.62 \\
0.84 \\
0.51 \\
0.71\end{array}$ \\
\hline $\begin{array}{l}0.02 \\
0.59 \\
0.73 \\
0.07 \\
0.78\end{array}$ & $\begin{array}{l}27.8 \pm 8.0 \\
13.8 \pm 17.6 \\
184.3 \pm 145.8 \\
192.9 \pm 72.4 \\
2027.3 \pm 517.4\end{array}$ & $\begin{array}{l}27.6 \pm 7.8 \\
11.2 \pm 12.2 \\
180.7 \pm 129.9 \\
188.0 \pm 110.6 \\
1997.0 \pm 449.1\end{array}$ & $\begin{array}{l}0.87 \\
0.30 \\
0.87 \\
0.74 \\
0.70\end{array}$ \\
\hline $\begin{array}{l}0.42 \\
0.20\end{array}$ & $\begin{array}{l}24.9 \pm 2.8 \\
9.7\end{array}$ & $\begin{array}{l}25.5 \pm 2.9 \\
11.9\end{array}$ & $\begin{array}{l}0.20 \\
0.66\end{array}$ \\
\hline 0.62 & $\begin{array}{l}25.8 \\
41.9 \\
32.3\end{array}$ & $\begin{array}{l}34.3 \\
43.3 \\
22.4\end{array}$ & 0.31 \\
\hline 0.98 & $\begin{array}{l}18.5 \\
27.2 \\
32.6 \\
21.7\end{array}$ & $\begin{array}{l}22.7 \\
27.3 \\
34.8 \\
15.2\end{array}$ & 0.73 \\
\hline
\end{tabular}

categories and one standard deviation (SD) of increase in fresh meat, meat products and fish, all based on the distribution in the subcohort. The lowest quartile or category of consumption was regarded as the reference category. The personyears at risk, estimated from the subcohort, were used in the denominator of the incidence rates (15). Standard errors were estimated using the robust Huber-White sandwich estimator to account for additional variance introduced by sampling from the cohort. This method is equivalent to the variance-covariance estimator as presented by Barlow (22). The proportional hazards assumption was tested using the scaled Schoenfeld residuals (23). Those variables that were found to contribute substantially $(p<0.10)$ to the multivariate model for colon and/or rectal cancer (age, sex, QI, smoking, energy intake and family history of CRC) were included as covariates in all multivariate analyses. Interactions between total fresh meat, meat products and fish consumption on one hand and sex on the other hand were tested for colon and rectal cancer separately and not found to be statistically significant. Therefore, results for men and women are presented together. Finally, age at baseline, sex, family history of CRC, smoking status, QI and the intake of energy were confounders for either one or both of the models, i.e. with colon or rectal cancer cases, and were therefore included as covariates for all models to be tested. For each analysis, linear trends were evaluated with the Wald test of the regression coefficient estimate by fitting ordinal exposure variables (quartiles/categories of consumption) as continuous terms. 
Table 2 Incidence rate ratios (RR) and 95\% confidence intervals $(\mathrm{Cl})$ for colon $(\mathrm{N}=448)$ and rectal $(\mathrm{N}=160)$ cancer patients overall according to the intake of total fresh meat, meat products and fish

\begin{tabular}{|c|c|c|c|c|c|c|c|}
\hline & \multicolumn{5}{|c|}{ Quartile/Category of intake } & \multirow{2}{*}{$\begin{array}{l}\text { RR }(95 \% \mathrm{Cl}) \text { for } \\
\text { one SD increase } \\
\text { in intake }\end{array}$} \\
\hline & & 11 & 2 & 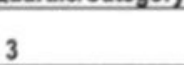 & 4 & $\begin{array}{l}\text { Pfor } \\
\text { trend }\end{array}$ & \\
\hline \multicolumn{8}{|c|}{$\begin{array}{l}\text { Total fresh meat } \\
\text { Median intake }(\mathrm{g} / \mathrm{d})\end{array}$} \\
\hline \multirow{5}{*}{\multicolumn{2}{|c|}{$\begin{array}{l}\text { men } \\
\text { women } \\
\text { colon cancer cases } \\
\text { rectum cancer cases } \\
\text { personyears }\end{array}$}} & \multirow{6}{*}{$\begin{array}{l}61.0 \\
50.7 \\
109 \\
40 \\
3661 \\
1.00 \\
1.00\end{array}$} & \multirow{6}{*}{$\begin{array}{l}91.0 \\
80.3 \\
112 \\
48 \\
3701 \\
1.03(0.77-1.37) \\
1.21(0.78-1.86)\end{array}$} & \multirow{6}{*}{$\begin{array}{l}110.7 \\
103.4 \\
123 \\
40 \\
3660 \\
1.16(0.88-1.54) \\
1.03(0.65-1.61)\end{array}$} & \multirow{6}{*}{$\begin{array}{l}150.8 \\
139.2 \\
104 \\
32 \\
3715 \\
0.99(0.74-1.33) \\
0.82(0.51-1.33)\end{array}$} & \multirow[b]{6}{*}{0.80} & \multirow[b]{6}{*}{$\begin{array}{l}0.97(0.89-1.07) \\
0.94(0.80-1.09)\end{array}$} \\
\hline & & & & & & & \\
\hline & & & & & & & \\
\hline & & & & & & & \\
\hline & & & & & & & \\
\hline $\operatorname{RR}(95 \% \mathrm{Cl})^{2}$ & $\begin{array}{l}\text { colon } \\
\text { rectum }\end{array}$ & & & & & & \\
\hline $\operatorname{RR}(95 \% \mathrm{Cl})^{3}$ & $\begin{array}{l}\text { colon } \\
\text { rectum }\end{array}$ & $\begin{array}{l}1.00 \\
1.00\end{array}$ & $\begin{array}{l}1.05(0.78-1.41) \\
1.11(0.71-1.73)\end{array}$ & $\begin{array}{l}1.12(0.83-1.49) \\
0.93(0.59-1.47)\end{array}$ & $\begin{array}{l}0.96(0.70-1.31) \\
0.72(0.44-1.19)\end{array}$ & $\begin{array}{l}0.92 \\
0.14\end{array}$ & $\begin{array}{l}0.96(0.87-1.06) \\
0.89(0.76-1.05)\end{array}$ \\
\hline \multicolumn{8}{|c|}{$\begin{array}{l}\text { Beef } \\
\text { Median intake }(\mathrm{g} / \mathrm{d})\end{array}$} \\
\hline \multirow{5}{*}{\multicolumn{2}{|c|}{$\begin{array}{l}\text { men } \\
\text { women } \\
\text { colon cancer cases } \\
\text { rectum cancer cases } \\
\text { personyears }\end{array}$}} & \multirow{6}{*}{$\begin{array}{l}4.1 \\
3.0 \\
100 \\
39 \\
3648 \\
1.00 \\
1.00\end{array}$} & \multirow{6}{*}{$\begin{array}{l}16.1 \\
14.0 \\
98 \\
49 \\
3742 \\
0.94(0.70-1.27) \\
1.22(0.79-1.88)\end{array}$} & \multirow{6}{*}{$\begin{array}{l}30.0 \\
25.5 \\
108 \\
32 \\
3507 \\
1.08(0.80-1.44) \\
0.84(0.52-1.37)\end{array}$} & \multirow{6}{*}{$\begin{array}{l}51.4 \\
46.9 \\
142 \\
40 \\
3840 \\
1.23(0.93-1.63) \\
0.90(0.57-1.43)\end{array}$} & & \\
\hline & & & & & & & \\
\hline & & & & & & & \\
\hline & & & & & & & \\
\hline & & & & & & & \\
\hline RR $(95 \%$ CI) & $\begin{array}{l}\text { colon } \\
\text { rectum }\end{array}$ & & & & & $\begin{array}{l}0.09 \\
0.35\end{array}$ & $\begin{array}{l}1.05(0.96-1.15) \\
0.95(0.79-1.13)\end{array}$ \\
\hline $\operatorname{RR}(95 \% \mathrm{Cl})^{3}$ & $\begin{array}{c}\text { colon } \\
\text { rectum }\end{array}$ & $\begin{array}{l}1.00 \\
1.00\end{array}$ & $\begin{array}{l}0.98(0.72-1.33) \\
1.25(0.80-1.96)\end{array}$ & $\begin{array}{l}1.09(0.81-1.48) \\
0.82(0.49-1.36)\end{array}$ & $\begin{array}{l}1.28(0.96-1.72) \\
0.92(0.57-1.49)\end{array}$ & $\begin{array}{l}0.06 \\
0.38\end{array}$ & $\begin{array}{l}1.06(0.97-1.17) \\
0.94(0.78-1.14)\end{array}$ \\
\hline \multirow{2}{*}{\multicolumn{8}{|c|}{$\begin{array}{l}\text { Pork } \\
\text { Median intake }(g / d)\end{array}$}} \\
\hline & & & & & & & \\
\hline men & & & 28.0 & 44.3 & 76.0 & & \\
\hline Women & & 5.0 & 22.5 & 40.1 & 66.2 & & \\
\hline colon cancer ca & & 121 & & & & & \\
\hline rectum cancer & & & & & & & \\
\hline personyears & & 3659 & 3658 & 3688 & 3733 & & \\
\hline $\operatorname{RR}(95 \% \mathrm{Cl})^{2}$ & $\begin{array}{l}\text { colon } \\
\text { rectum }\end{array}$ & $\begin{array}{l}1.00 \\
1.00\end{array}$ & $\begin{array}{l}1.03(0.78-1.35) \\
1.07(0.70-1.64)\end{array}$ & $\begin{array}{l}0.94(0.71-1.24) \\
0.84(0.53-1.33)\end{array}$ & $\begin{array}{l}0.86(0.76-1.37) \\
0.80(0.50-1.28)\end{array}$ & $\begin{array}{l}0.24 \\
0.22\end{array}$ & $\begin{array}{l}0.96(0.87-1.07) \\
0.90(0.76-1.07)\end{array}$ \\
\hline $\operatorname{RR}(95 \% \mathrm{Cl})^{3}$ & colon & 1.00 & $0.98(0.74-1.30)$ & $0.90(0.67-1.20)$ & $0.77(0.57-1.04)$ & 0.07 & $0.93(0.83-1.04)$ \\
\hline Minced Meat & & & & & & & \\
\hline Median intake ( & & & & & & & \\
\hline men & & 3.2 & 11.5 & 21.0 & 37.8 & & \\
\hline Women & & 0.0 & & 18.1 & 32.9 & & \\
\hline colon cancer ca & & 104 & & 128 & & & \\
\hline rectum cancer & & 33 & & & & & \\
\hline personyears & & 3648 & & & 3679 & & \\
\hline $\operatorname{RR}(95 \% \mathrm{Cl})^{2}$ & colon & 1.00 & $1.12(0.84-1.49)$ & $1.28(0.97-1.70)$ & $0.95(0.70-1.28)$ & 0.99 & $0.95(0.86-1.04)$ \\
\hline & rectum & 1.00 & $1.13(0.70-1.82)$ & $1.67(1.07-2.61)$ & $1.07(0.66-1.74)$ & 0.38 & $1.09(0.94-1.26)$ \\
\hline $\operatorname{RR}(95 \% \mathrm{Cl})^{3}$ & $\begin{array}{l}\text { colon } \\
\text { rectum }\end{array}$ & $\begin{array}{l}1.00 \\
1.00\end{array}$ & $\begin{array}{l}1.11(0.83-1.50) \\
1.06(0.66-1.73)\end{array}$ & $\begin{array}{l}1.26(0.94-1.69) \\
1.60(1.01-2.52)\end{array}$ & $\begin{array}{l}0.93(0.68-1.27) \\
1.01(0.62-1.67)\end{array}$ & $\begin{array}{l}0.88 \\
0.50\end{array}$ & $\begin{array}{l}0.95(0.85-1.05) \\
1.08(0.92-1.27)\end{array}$ \\
\hline Liver & & & & & & & \\
\hline Median intake & & & & & & & \\
\hline men & & 0.0 & 4.1 & & & & \\
\hline Women & & 0.0 & & & & & \\
\hline colon cancer ce & & 295 & 153 & & & & \\
\hline rectum cancer & & 99 & & & & & \\
\hline personyears & & 9589 & 5148 & & & & \\
\hline $\operatorname{RR}(95 \% \mathrm{Cl})^{2}$ & $\begin{array}{l}\text { colon } \\
\text { rectum }\end{array}$ & $\begin{array}{l}1.00 \\
1.00\end{array}$ & $\begin{array}{l}1.02(0.83-1.26) \\
1.16(0.83-1.62)\end{array}$ & & & $\begin{array}{l}0.84 \\
0.38\end{array}$ & $\begin{array}{l}1.00(0.91-1.11) \\
1.02(0.88-1.18)\end{array}$ \\
\hline $\operatorname{RR}(95 \% \mathrm{Cl})^{3}$ & $\begin{array}{l}\text { colon } \\
\text { rectum }\end{array}$ & $\begin{array}{l}1.00 \\
1.00\end{array}$ & $\begin{array}{l}1.04(0.84-1.29) \\
1.11(0.79-1.57)\end{array}$ & & & $\begin{array}{l}0.71 \\
0.54\end{array}$ & $\begin{array}{l}1.02(0.92-1.12) \\
1.02(0.88-1.18)\end{array}$ \\
\hline
\end{tabular}


Table 2 continued

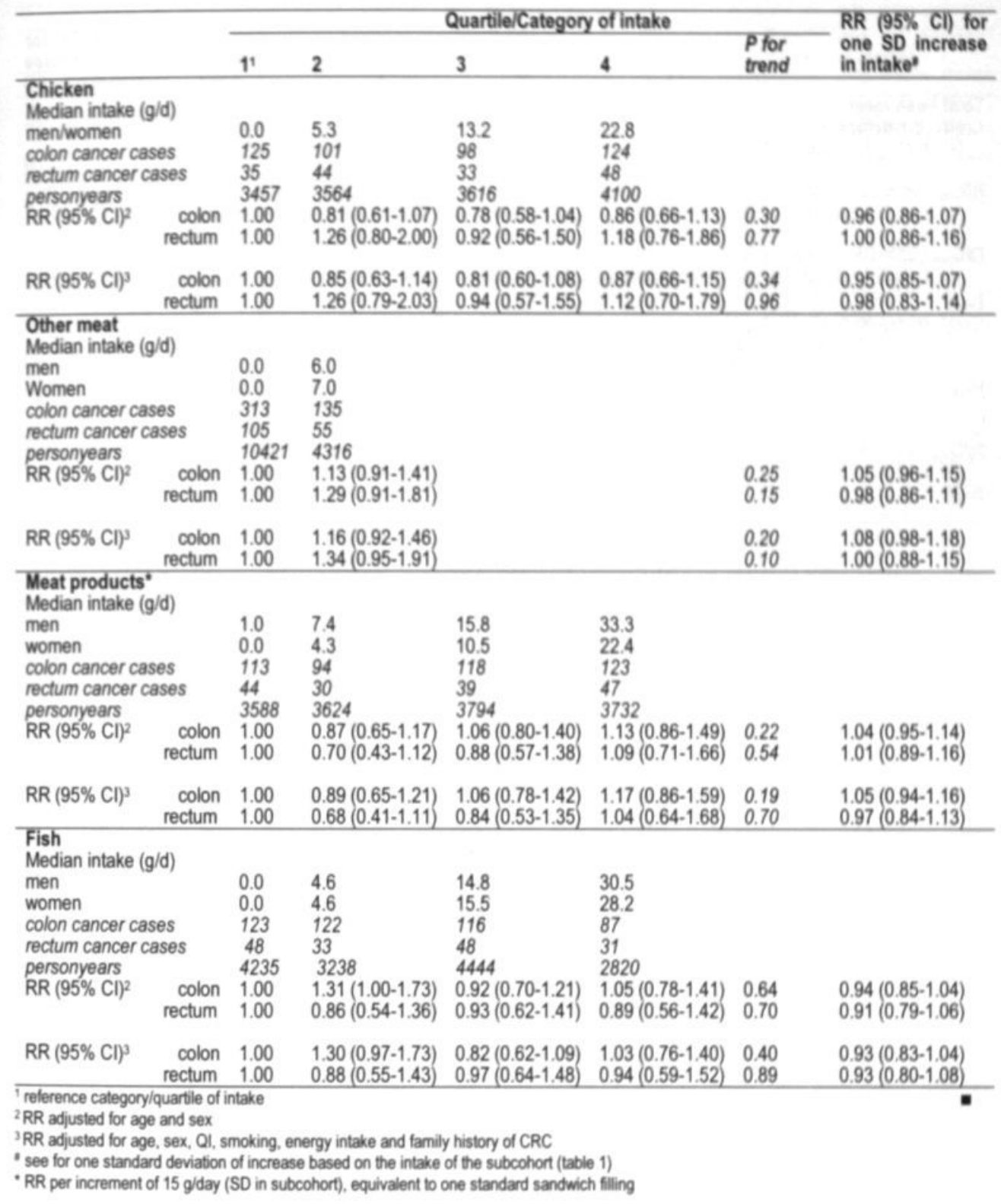

\section{RESULTS}

The overall frequency and spectrum of mutations in the $K$-ras gene have been presented in detail elsewhere (9). In brief, a total of 227 mutations was found in 218 (36\%) out of 608 colon and rectal cancer patients. The most frequently observed mutations are the 
Table 3 Adjusted RR ${ }^{1}$ for colon and rectal cancer patients with a $K$-ras mutation status ${ }^{2}$ according to the intake of fresh meat, meat products and fish

\begin{tabular}{|c|c|c|c|c|c|c|}
\hline & \multicolumn{5}{|c|}{ Quartile/Category of intake } & \multirow{2}{*}{$\begin{array}{l}\text { RR }(95 \% \mathrm{Cl}) \text { for } \\
\text { one SD increase } \\
\text { in intake }\end{array}$} \\
\hline & $1^{3}$ & 2 & 3 & 4 & $\begin{array}{l}\text { Pfor } \\
\text { trend }\end{array}$ & \\
\hline \multicolumn{7}{|l|}{$\begin{array}{l}\text { Total fresh meat } \\
\text { Cases (K-ras-/K-ras+) }\end{array}$} \\
\hline $\begin{array}{r}\text { colon } \\
\text { rectum }\end{array}$ & $\begin{array}{l}68 / 35 \\
25 / 15\end{array}$ & $\begin{array}{l}80 / 29 \\
21 / 24\end{array}$ & $\begin{array}{l}76 / 45 \\
25 / 14\end{array}$ & $\begin{array}{l}66 / 35 \\
18 / 12\end{array}$ & & \\
\hline $\mathrm{RR}_{\mathrm{K}=\mathrm{s}}(95 \% \mathrm{Cl}) \begin{array}{c}\text { colon } \\
\text { rectum }\end{array}$ & $\begin{array}{l}1.00 \\
1.00\end{array}$ & $\begin{array}{l}1.16(0.82-1.64) \\
0.85(0.47-1.55)\end{array}$ & $\begin{array}{l}1.05(0.74-1.49) \\
1.02(0.58-1.80)\end{array}$ & $\begin{array}{l}0.94(0.65-1.36) \\
0.76(0.41-1.44)\end{array}$ & $\begin{array}{l}0.61 \\
0.56\end{array}$ & $\begin{array}{l}0.95(0.84-1.07) \\
0.93(0.75-1.15)\end{array}$ \\
\hline $\begin{array}{r}R_{\text {K-w }}(95 \% \mathrm{Cl}) \\
\begin{array}{c}\text { colon } \\
\text { rectum }\end{array}\end{array}$ & $\begin{array}{l}1.00 \\
1.00\end{array}$ & $\begin{array}{l}0.83(0.50-1.37) \\
1.53(0.80-2.94)\end{array}$ & $\begin{array}{l}1.25(0.79-2.00) \\
0.82(0.39-1.72)\end{array}$ & $\begin{array}{l}1.01(0.61-1.66) \\
0.68(0.31-1.47)\end{array}$ & $\begin{array}{l}0.57 \\
0.10\end{array}$ & $\begin{array}{l}0.99(0.85-1.16) \\
0.85(0.67-1.07)\end{array}$ \\
\hline \multicolumn{7}{|l|}{$\begin{array}{l}\text { Beef } \\
\text { Cases (K-ras-/K-ras+) }\end{array}$} \\
\hline $\begin{array}{r}\text { colon } \\
\text { rectum }\end{array}$ & $\begin{array}{l}62 / 32 \\
21 / 16\end{array}$ & $\begin{array}{l}66 / 29 \\
25 / 23\end{array}$ & $\begin{array}{l}66 / 39 \\
18 / 12\end{array}$ & $\begin{array}{l}96 / 44 \\
25 / 14\end{array}$ & & \\
\hline$R_{\text {K.m }}(95 \% \mathrm{Cl}) \begin{array}{c}\text { colon } \\
\text { rectum }\end{array}$ & $\begin{array}{l}1.00 \\
1.00\end{array}$ & $\begin{array}{l}1.04(0.72-1.49) \\
1.16(0.64-2.12)\end{array}$ & $\begin{array}{l}1.05(0.72-1.51) \\
0.89(0.46-1.71)\end{array}$ & $\begin{array}{l}1.36(0.96-1.93) \\
1.06(0.57-1.94)\end{array}$ & $\begin{array}{l}0.08 \\
0.93\end{array}$ & $\begin{array}{l}1.08(0.97-1.20) \\
1.02(0.81-1.27)\end{array}$ \\
\hline $\begin{array}{c}\mathrm{RR}_{\text {Kam }}(95 \% \mathrm{Cl}) \begin{array}{c}\text { colon } \\
\text { rectum }\end{array} \\
\end{array}$ & $\begin{array}{l}1.00 \\
1.00\end{array}$ & $\begin{array}{l}0.87(0.52-1.47) \\
1.36(0.70-2.63)\end{array}$ & $\begin{array}{l}1.18(0.73-1.92) \\
0.74(0.34-1.61)\end{array}$ & $\begin{array}{l}1.14(0.71-1.83) \\
0.75(0.35-1.61)\end{array}$ & $\begin{array}{l}0.38 \\
0.20 \\
\end{array}$ & $\begin{array}{l}1.04(0.89-1.22) \\
0.84(0.61-1.16)\end{array}$ \\
\hline \multicolumn{7}{|c|}{$\begin{array}{l}\text { Pork } \\
\text { Cases (K-ras-/K-ras+) }\end{array}$} \\
\hline $\begin{array}{r}\text { colon } \\
\text { rectum }\end{array}$ & $\begin{array}{l}85 / 33 \\
31 / 12\end{array}$ & $\begin{array}{l}74 / 42 \\
25 / 19\end{array}$ & $\begin{array}{l}68 / 40 \\
18 / 18\end{array}$ & $\begin{array}{l}63 / 29 \\
15 / 16\end{array}$ & & \\
\hline $\mathrm{RR}_{\mathrm{K}=\mathrm{*}}(95 \% \mathrm{Cl}) \begin{array}{c}\text { colon } \\
\text { rectum }\end{array}$ & $\begin{array}{l}1.00 \\
1.00\end{array}$ & $\begin{array}{l}0.86(0.61-1.20) \\
0.81(0.48-1.39)\end{array}$ & $\begin{array}{l}0.77(0.55-1.08) \\
0.58(0.32-1.04)\end{array}$ & $\begin{array}{l}0.72(0.51-1.02) \\
0.50(0.26-0.93)\end{array}$ & $\begin{array}{l}0.05 \\
0.01\end{array}$ & $\begin{array}{l}0.91(0.80-1.05) \\
0.74(0.57-0.96)\end{array}$ \\
\hline $\begin{array}{c}R_{\text {Kan }}(95 \% \mathrm{Cl}) \begin{array}{c}\text { colon } \\
\text { rectum }\end{array} \\
\end{array}$ & $\begin{array}{l}1.00 \\
1.00\end{array}$ & $\begin{array}{l}1.30(0.80-2.09) \\
1.52(0.73-3.17)\end{array}$ & $\begin{array}{l}1.24(0.76-2.02) \\
1.38(0.65-2.94)\end{array}$ & $\begin{array}{l}0.90(0.53-1.53) \\
1.21(0.56-2.60)\end{array}$ & $\begin{array}{l}0.68 \\
0.75 \\
\end{array}$ & $\begin{array}{l}0.97(0.82-1.15) \\
1.03(0.82-1.29)\end{array}$ \\
\hline \multicolumn{7}{|l|}{$\begin{array}{l}\text { Minced Meat } \\
\text { Cases (K-ras-/K-ras+) }\end{array}$} \\
\hline $\begin{array}{r}\text { colon } \\
\text { rectum }\end{array}$ & $\begin{array}{l}66 / 34 \\
19 / 14\end{array}$ & $\begin{array}{l}79 / 37 \\
17 / 19\end{array}$ & $\begin{array}{l}89 / 36 \\
32 / 20\end{array}$ & $\begin{array}{l}56 / 37 \\
21 / 12\end{array}$ & & \\
\hline $\begin{array}{r}\mathrm{RR}_{\text {K }=1}(95 \% \mathrm{CI}) \\
\text { rectum }\end{array}$ & $\begin{array}{l}1.00 \\
1.00\end{array}$ & $\begin{array}{l}1.16(0.82-1.64) \\
0.89(0.46-1.74)\end{array}$ & $\begin{array}{l}1.37(0.97-1.92) \\
1.77(0.99-3.19)\end{array}$ & $\begin{array}{l}0.85(0.58-1.25) \\
1.17(0.62-2.19)\end{array}$ & $\begin{array}{l}0.68 \\
0.21\end{array}$ & $\begin{array}{l}0.93(0.82-1.04) \\
1.18(0.99-1.40)\end{array}$ \\
\hline $\begin{array}{r}\mathrm{RR}_{\text {Ktan }}(95 \% \mathrm{Cl}) \begin{array}{c}\text { colon } \\
\text { rectum }\end{array} \\
\end{array}$ & $\begin{array}{l}1.00 \\
1.00 \\
\end{array}$ & $\begin{array}{l}1.04(0.64-1.68) \\
1.28(0.64-2.56)\end{array}$ & $\begin{array}{l}1.06(0.64-1.74) \\
1.36(0.68-2.72)\end{array}$ & $\begin{array}{l}1.07(0.65-1.75) \\
0.81(0.37-1.79)\end{array}$ & $\begin{array}{l}0.78 \\
0.66\end{array}$ & $\begin{array}{l}0.98(0.83-1.16) \\
0.87(0.68-1.12)\end{array}$ \\
\hline \multicolumn{7}{|c|}{$\begin{array}{l}\text { Liver } \\
\text { Cases (K-ras-/K-ras+) }\end{array}$} \\
\hline RR $_{\text {K.as }}(95 \% \mathrm{Cl}) \begin{array}{c}\text { colon } \\
\text { rectum } \\
\text { colon } \\
\text { rectum }\end{array}$ & $\begin{array}{l}184 / 98 \\
55 / 41 \\
1.00 \\
1.00\end{array}$ & $\begin{array}{l}106 / 46 \\
34 / 24 \\
1.10(0.86-1.42) \\
1.15(0.74-1.79)\end{array}$ & & & $\begin{array}{l}0.44 \\
0.54\end{array}$ & $\begin{array}{l}1.02(0.91-1.14) \\
1.05(0.89-1.24)\end{array}$ \\
\hline $\begin{array}{r}R_{\text {Kras }}(95 \% \mathrm{Cl}) \begin{array}{r}\text { colon } \\
\text { rectum }\end{array} \\
\end{array}$ & $\begin{array}{l}1.00 \\
1.00\end{array}$ & $\begin{array}{l}0.92(0.63-1.33) \\
1.07(0.63-1.80)\end{array}$ & & & $\begin{array}{l}0.65 \\
0.80\end{array}$ & $\begin{array}{l}1.01(0.85-1.19) \\
0.97(0.74-1.28)\end{array}$ \\
\hline \multicolumn{7}{|c|}{$\begin{array}{l}\text { Chicken } \\
\text { Cases (K-ras-/K-ras+) }\end{array}$} \\
\hline $\begin{array}{r}\text { colon } \\
\text { rectum }\end{array}$ & $\begin{array}{l}73 / 42 \\
20 / 13\end{array}$ & $\begin{array}{l}73 / 27 \\
24 / 19\end{array}$ & $\begin{array}{l}62 / 35 \\
16 / 17\end{array}$ & $\begin{array}{l}82 / 40 \\
29 / 16\end{array}$ & & \\
\hline$R_{K-w}(95 \% \mathrm{Cl}) \begin{array}{c}\text { colon } \\
\text { rectum }\end{array}$ & $\begin{array}{l}1.00 \\
1.00\end{array}$ & $\begin{array}{l}0.96(0.68-1.36) \\
1.19(0.64-2.18)\end{array}$ & $\begin{array}{l}0.81(0.57-1.16) \\
0.76(0.39-1.49)\end{array}$ & $\begin{array}{l}0.91(0.65-1.28) \\
1.23(0.69-2.21)\end{array}$ & $\begin{array}{l}0.44 \\
0.75\end{array}$ & $\begin{array}{l}0.96(0.84-1.09) \\
1.04(0.85-1.26)\end{array}$ \\
\hline $\begin{array}{r}R_{\text {K-nas }}(95 \% \mathrm{Cl}) \begin{array}{c}\text { colon } \\
\text { rectum }\end{array} \\
\end{array}$ & $\begin{array}{l}1.00 \\
1.00\end{array}$ & $\begin{array}{l}0.64(0.39-1.06) \\
1.39(0.68-2.85)\end{array}$ & $\begin{array}{l}0.80(0.51-1.28) \\
1.20(0.57-2.53)\end{array}$ & $\begin{array}{l}0.80(0.51-1.26) \\
0.97(0.46-2.03)\end{array}$ & $\begin{array}{l}0.52 \\
0.75\end{array}$ & $\begin{array}{l}0.95(0.79-1.14) \\
0.88(0.68-1.15)\end{array}$ \\
\hline \multicolumn{7}{|l|}{$\begin{array}{l}\text { Other meat } \\
\text { Cases (K-ras-/K-ras+) }\end{array}$} \\
\hline $\begin{array}{r}\text { colon } \\
\text { rectum }\end{array}$ & $\begin{array}{l}201 / 110 \\
57 / 43\end{array}$ & $\begin{array}{l}89 / 43 \\
32 / 22\end{array}$ & & & & \\
\hline $\begin{array}{r}R_{\text {Kras }}(95 \% \mathrm{Cl}) \begin{array}{r}\text { colon } \\
\text { rectum }\end{array} \\
\end{array}$ & $\begin{array}{l}1.00 \\
1.00\end{array}$ & $\begin{array}{l}1.16(0.89-1.52) \\
0.90(0.63-2.23)\end{array}$ & & & $\begin{array}{l}0.28 \\
0.14\end{array}$ & $\begin{array}{l}1.08(0.96-1.21) \\
0.97(0.81-1.17)\end{array}$ \\
\hline
\end{tabular}




\begin{tabular}{|c|c|c|c|c|c|c|}
\hline & \multicolumn{5}{|c|}{ Quartile/Category of intake } & \multirow{2}{*}{$\begin{array}{l}R R(95 \% \mathrm{Cl}) \text { for } \\
\text { one } S D \text { increase } \\
\text { in intake }\end{array}$} \\
\hline & $1^{3}$ & 2 & \multirow[t]{2}{*}{3} & 4 & $\begin{array}{l}\text { P for } \\
\text { trend }\end{array}$ & \\
\hline \multicolumn{6}{|l|}{ Other meat } & \\
\hline $\begin{array}{c}R R_{k=*}(95 \% \mathrm{Cl}) \begin{array}{c}\text { colon } \\
\text { rectum }\end{array} \\
\end{array}$ & $\begin{array}{l}1.00 \\
1.00\end{array}$ & $\begin{array}{l}1.16(0.79-1.70) \\
1.24(0.73-2.10)\end{array}$ & & & $\begin{array}{l}0.44 \\
0.43\end{array}$ & $\begin{array}{l}1.07(0.93-1.23) \\
1.04(0.87-1.24)\end{array}$ \\
\hline \multicolumn{7}{|l|}{$\begin{array}{l}\text { Meat products } \\
\text { Cases (K-ras-/K-ras+) }\end{array}$} \\
\hline $\begin{array}{r}\text { colon } \\
\text { rectum }\end{array}$ & $\begin{array}{l}65 / 40 \\
28 / 14\end{array}$ & $\begin{array}{l}59 / 33 \\
20 / 9\end{array}$ & $\begin{array}{l}76 / 41 \\
18 / 20\end{array}$ & $\begin{array}{l}90 / 30 \\
23 / 22\end{array}$ & & \\
\hline$R_{R K=}(95 \% \mathrm{Cl}) \begin{array}{c}\text { colon } \\
\text { rectum }\end{array}$ & $\begin{array}{l}1.00 \\
1.00\end{array}$ & $\begin{array}{l}0.91(0.63-1.33) \\
0.71(0.39-1.30)\end{array}$ & $\begin{array}{l}1.10(0.76-1.57) \\
0.62(0.34-1.16)\end{array}$ & $\begin{array}{l}1.42(1.00-2.03) \\
0.84(0.45-1.58)\end{array}$ & $\begin{array}{l}0.03 \\
0.51\end{array}$ & $\begin{array}{l}1.115(0.99-1.25) \\
0.91(0.73-1.14)\end{array}$ \\
\hline $\begin{array}{c}\text { RRkw } \\
(95 \% \mathrm{Cl}) \\
\text { rectum }\end{array}$ & $\begin{array}{l}1.00 \\
1.00 \\
\end{array}$ & $\begin{array}{l}0.84(0.52-1.37) \\
0.62(0.26-1.46)\end{array}$ & $\begin{array}{l}1.00(0.63-1.59) \\
1.26(0.61-2.61)\end{array}$ & $\begin{array}{l}0.77(0.45-1.32) \\
1.41(0.67-2.99)\end{array}$ & $\begin{array}{l}0.51 \\
0.17 \\
\end{array}$ & $\begin{array}{l}0.90(0.73-1.11) \\
1.05(0.86-1.27)\end{array}$ \\
\hline \multicolumn{7}{|l|}{$\begin{array}{l}\text { Fish } \\
\text { Cases (K-ras-/K-ras+) }\end{array}$} \\
\hline $\begin{array}{r}\text { colon } \\
\text { rectum }\end{array}$ & $\begin{array}{l}84 / 37 \\
25 / 19\end{array}$ & $\begin{array}{l}81 / 36 \\
20 / 11\end{array}$ & $\begin{array}{l}74 / 35 \\
24 / 24\end{array}$ & $\begin{array}{l}51 / 36 \\
20 / 11\end{array}$ & & \\
\hline $\begin{array}{r}R R=1 \\
(95 \% \mathrm{Cl}) \\
\begin{array}{c}\text { colon } \\
\text { rectum }\end{array}\end{array}$ & $\begin{array}{l}1.00 \\
1.00\end{array}$ & $\begin{array}{l}1.30(0.93-1.81) \\
0.97(0.53-1.79)\end{array}$ & $\begin{array}{l}0.80(0.57-1.12) \\
0.86(0.48-1.52)\end{array}$ & $\begin{array}{l}0.87(0.60-1.26) \\
1.06(0.58-1.94)\end{array}$ & $\begin{array}{l}0.13 \\
0.99\end{array}$ & $\begin{array}{l}0.88(0.77-1.02) \\
0.97(0.81-1.17)\end{array}$ \\
\hline $\begin{array}{r}R_{\text {Kaw }}(95 \% \mathrm{Cl}) \begin{array}{c}\text { colon } \\
\text { rectum }\end{array} \\
\end{array}$ & $\begin{array}{l}1.00 \\
1.00 \\
\end{array}$ & $\begin{array}{l}1.29(0.79-2.10) \\
0.76(0.35-1.61)\end{array}$ & $\begin{array}{l}0.87(0.54-1.42) \\
1.13(0.61-2.07)\end{array}$ & $\begin{array}{l}1.38(0.85-2.25) \\
0.78(0.37-1.65)\end{array}$ & $\begin{array}{l}0.52 \\
0.84 \\
\end{array}$ & $\begin{array}{l}1.00(0.85-1.19) \\
0.86(0.69-1.07)\end{array}$ \\
\hline $\begin{array}{l}\text { Multivariate adjusted RR for ag } \\
\text { confidence intervals } \\
\text { Wild type K-ras (K-ras): no mut } \\
\text { mutation in the exon } 1 \text { fragmen } \\
\text { Reference category/quartile of } \\
\text { See for one standard deviation } \\
\text { RR per increment of } 15 \text { g/day ( }\end{array}$ & $\begin{array}{l}\text { tation in } \\
\text { th of the } \\
\text { intake } \\
\text { of increa } \\
\text { SD in su }\end{array}$ & In 1 fragment of the & ene, mutated $K$-ras ( $K$ & $\begin{array}{l}\mathrm{RC} \text { and their } 95 \% \\
\left(-\operatorname{ros}^{*}\right) \text { : at least one }\end{array}$ & & $=$ \\
\hline
\end{tabular}

$\mathrm{G}>\mathrm{A}$ transitions $(54 \%), \mathrm{G}>\mathrm{T}$ transversions $(33 \%)$ and $\mathrm{G}>\mathrm{C}$ transversions $(7 \%)$. The observed frequencies of the mutations in this series of patients are similar to the frequencies of the 737 CRC cases, including the rectosigmoid cancer cases, for whom K-ras mutation status was determined (9).

Table 1 shows the baseline characteristics of the study population. Colon and rectal cancer cases were more often men, were older, more frequently reported a family history of CRC, had a higher daily alcohol intake and were less frequently never smokers as compared to the subcohort. Colon cancer cases with a K-ras mutation in their tumour had a lower daily consumption of meat products, a higher intake of dietary fibers and were significantly older than colon cancer cases with a wild type $K$-ras tumour (p-values 0.02 , 0.02 and 0.006 , respectively). There were no statistically significant differences between colon cancer cases with and without a $K$-ras mutation in their tumour in dietary consumption of total fresh meat, beef, pork, minced meat, liver, chicken, other meat, fish and other factors presented in table 1. Rectal cancer cases with a K-ras mutation in their tumour had a lower daily consumption of minced meat, a higher daily consumption of pork and were less frequently men than rectal cancer cases with a wild type $K$-ras gene in their tumour (p-values $0.03,0.06$ and 0.03 , respectively). No statistically significant differences were observed between rectal cancer cases with and without a $K$-ras mutation in their tumours for other factors presented in table 1.

Associations between the consumption of total fresh meat, different types of fresh meat, i.e. beef, pork, minced meat, liver, chicken and other meat, meat products and fish, and the risk of colon or rectal cancer are presented in table 2. RR and $95 \% \mathrm{Cl}$ for colon and rectal cancer were presented after adjustment for age and sex and after adjustment for age, 
Table 4 Adjusted RR' for colon and rectal cancer patients with specific point mutations ${ }^{2}$ in the $K$-ras oncogene according to the intake of fresh meat, meat products and fish

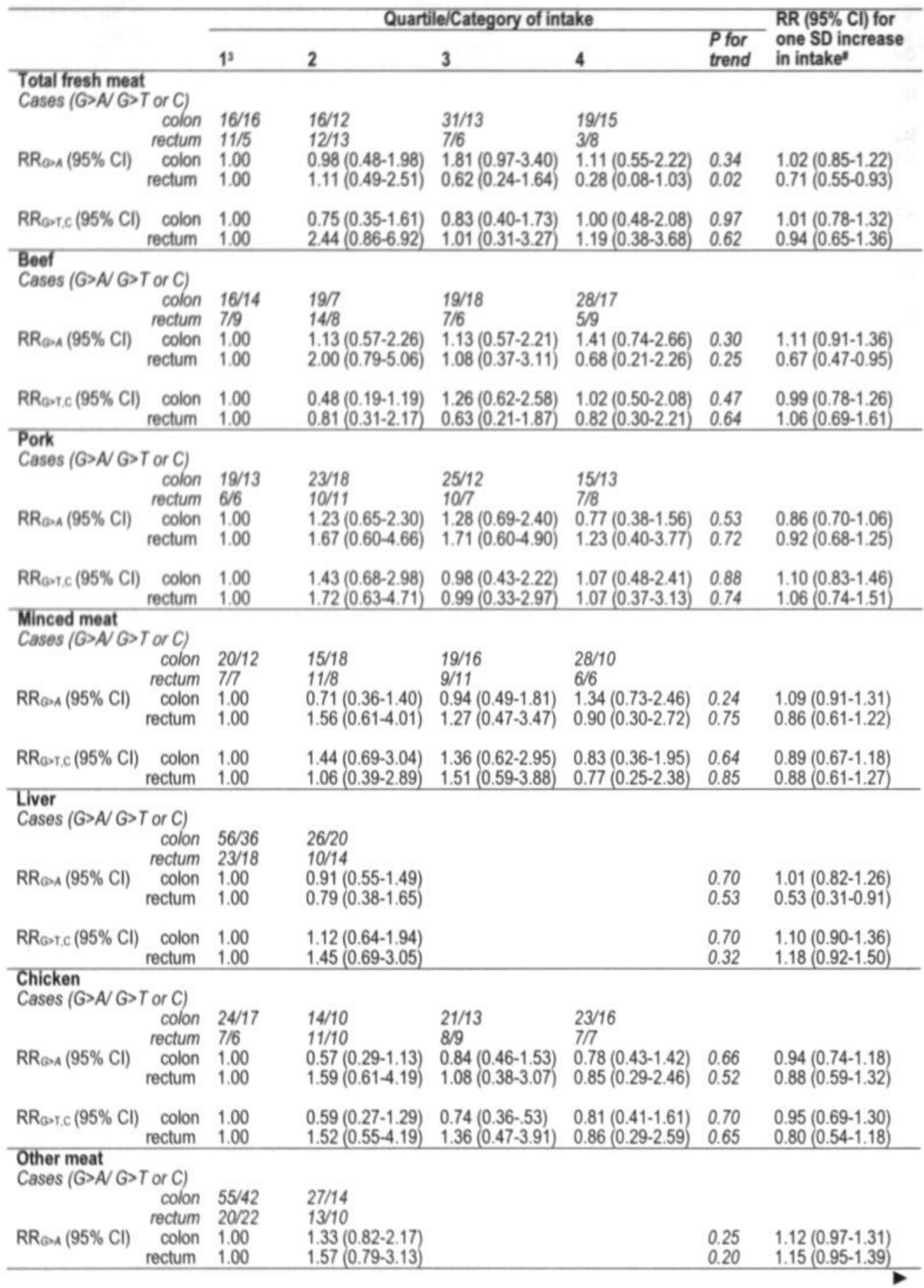




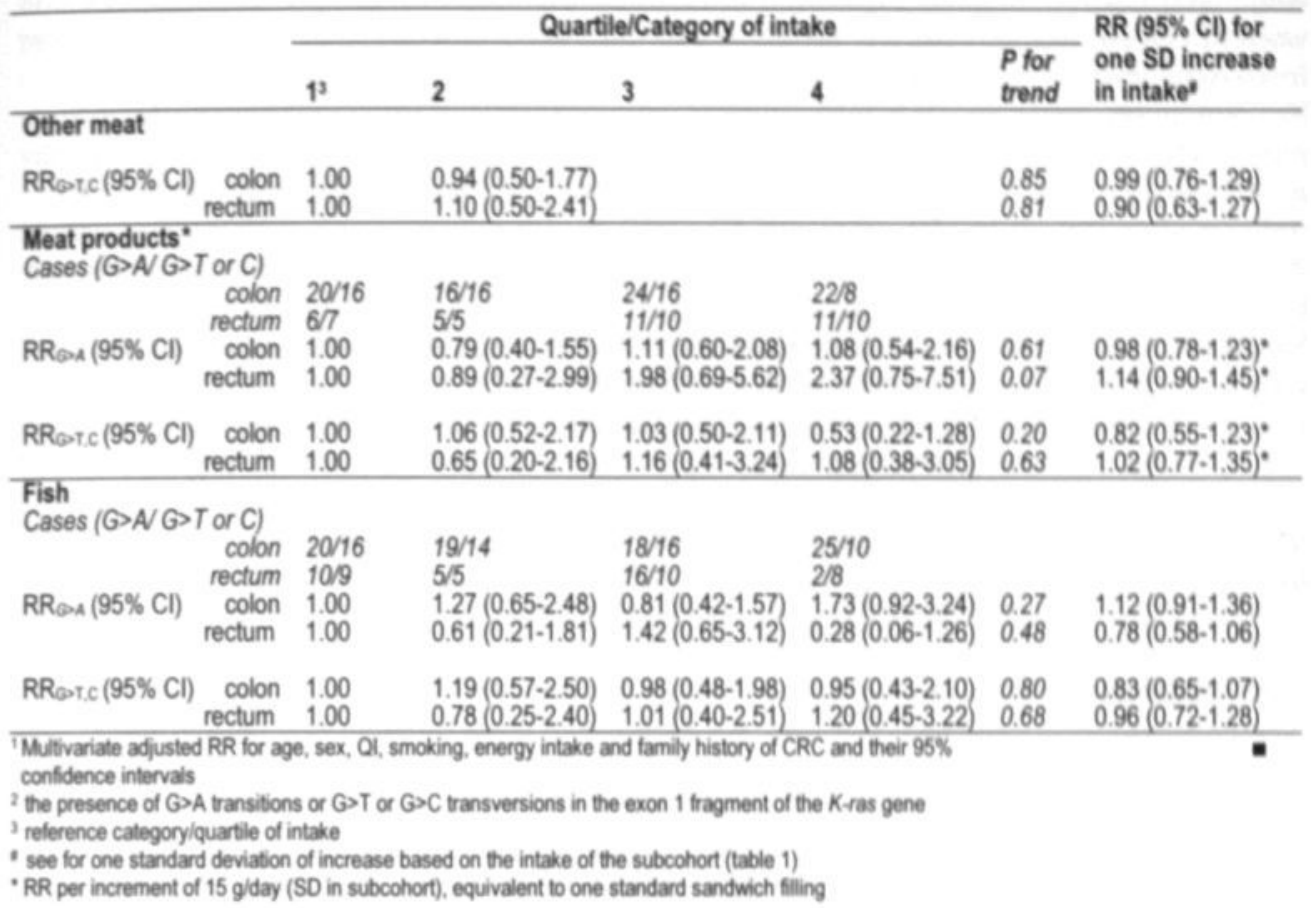

sex, smoking, QI, energy intake and family history of CRC. The age-and-sex adjusted RR and the multivariate RR were similar. Frequent consumption of total fresh meat, minced meat, liver, chicken, other meat, meat products and fish was not significantly associated with the risk of colon or rectal cancer (table 2). A high intake of beef was borderline positively associated with the risk of colon cancer (RR for highest versus lowest quartile of consumption $1.28,95 \% \mathrm{Cl} 0.96-1.72 ; p_{\text {trend }} 0.06$ ). There was no association between beef and rectal cancer risk. A high consumption of pork was, however, borderline inversely associated with the risk of colon cancer (RR for highest versus lowest quartile of consumption $0.77,95 \% \mathrm{Cl} 0.57-1.04$; $p_{\text {trend }} 0.07$ ) and rectal cancer (RR for highest versus lowest quartile of consumption $0.70,95 \% \mathrm{Cl} 0.43-1.13$; p prend 0.09 ).

Associations of total fresh meat, beef, pork, minced meat, liver, chicken, other meat, and meat products and fish with wild type or mutated $K$-ras gene in colon or rectal tumours are presented in table 3 . Results will first be presented for tumours with a wild type K-ras gene. No clear associations were observed for the highest versus the lowest consumption of total fresh meat, minced meat, liver, chicken, other meat and fish and colon and rectal tumours with a wild type $K$-ras gene. A nonsignificant, increased association was observed between beef and wild type $K$-ras colon tumours (RR for highest versus lowest quartile of consumption 1.36, $95 \% \mathrm{Cl} 0.96-1.93 ; p_{\text {trend }} 0.08$ ). No association was observed for beef and rectal tumours with a wild type $K$-ras gene. On the other hand, a high consumption of pork was inversely associated with wild type $K$-ras colon and rectal tumours (RR for highest versus lowest quartile of consumption $0.72,95 \% \mathrm{Cl} 0.51-1.02$ and $0.50,95 \% \mathrm{Cl} 0.26-0.93$, respectively). A high consumption of meat products showed a significant increased association with colon tumours with a wild type $K$-ras gene (RR for highest versus lowest quartile of intake 1.42, 95\% Cl 1.00-2.03; Ptrend 0.03 ). No clear association was found for 
high consumption of meat products and rectal tumours with a wild type $K$-ras gene. Regarding colon and rectal tumours that harbour a $K$-ras mutation, no clear associations were observed between highest versus lowest quartile of consumption of different types of fresh meat, meat products and fish.

Subgroup analyses were performed to evaluate the associations between total fresh meat, different types of fresh meat, meat products and fish, and specific types of $K$-ras point mutations ( $\mathrm{G}>\mathrm{A}$ transitions and $\mathrm{G}>\mathrm{T}$ or $\mathrm{G}>\mathrm{C}$ transversions) in colon and rectal tumours (table 4). Results will first be presented for tumours with a $G>A$ transition in the $K$-ras gene. Total fresh meat consumption was not associated with $G>A$ transitions in the colon tumours, but an inverse association with $G>A$ transitions in the rectal tumours was observed. However, none of the specific types of fresh meat, i.e. beef, pork, minced meat, liver, chicken, other meat, neither fish were associated with the risk of G>A transitions in both colon and rectal tumours. For meat products, a borderline significant trend with increased risk of rectal tumours harbouring G>A transitions was observed (RR for highest versus lowest quartile of intake 2.37, 95\% Cl 0.75-7.51; ptrend 0.07). Regarding G>T or G>C transversions in colon and rectal tumours, no clear associations were observed for total fresh meat, the different types of fresh meat, meat products and fish.

\section{DISCUSSION}

In this large cohort study with 448 incident colon and 160 incident rectal cancer patients, no associations were observed between total fresh meat and fish, and the risk of colon or rectal cancer, either overall or after $K$-ras mutation status was taken into account. This was also observed for specific types of fresh meat. However, several weak associations were observed regarding tumours harbouring a wild type $K$-ras gene. An increased association for high consumption of beef and an inverse association for high consumption of pork, and the risk of colon tumours were observed. In addition, consumption of pork was also inversely associated with rectal tumours with a wild type K-ras gene. For meat products, an increased association was observed with wild type $K$-ras tumours in the colon and with $\mathrm{G}>\mathrm{A}$ transitions in the $K$-ras gene in rectal tumours.

Earlier results on meat and CRC in the NLCS, based on 3.3 years of follow-up, showed no association for high consumption of total fresh meat and fish and colon cancer risk in men and women. A positive association for both men and women was observed for meat products which consists mainly of cured meat (24). Rectal cancer was not included in these analyses. These findings were in line with the findings of a meta-analysis conducted by Norat et al (3). In total, 29 studies were evaluated, including 22 case-control and 7 cohort studies for investigating the association between processed meat and CRC. A high consumption of processed meat was found to be associated with a moderate, but significant, increase in CRC risk. In the current study, after 7.3 years of follow-up and with the exclusion of the first 2.3 years, these findings were similar to the earlier results on meat and CRC in the NLCS, i.e. neither an association was observed for total fresh meat, different types of fresh meat, nor for fish. However, in the current study, no significant association was observed between meat products and colon or rectal cancer risk overall.

With regard to $K$-ras mutations, two case-control studies with colon cancer patients, one with 2418 patients and 2410 controls (25), the other with 185 patients $(26,27)$, and one cross-sectional case-case study with rectal cancer patients (28) have previously been conducted and have reported on the association between meat consumption and $K$-ras mutations. In none of these studies an association between meat consumption and colon or rectal cancer was observed after the $K$-ras gene mutation status was taken into account. 
The current cohort study on total fresh meat, different types of fresh meat, meat products and fish and specific $K$-ras mutations is, to our knowledge, the only prospective study performed to date. The prospective design of this study and the high completeness of followup of cancer incidence and of the subcohort, make information and selection bias unlikely. In addition, as a result of the exclusion of the first 2.3 years of follow-up, the chance of information bias due to potential preclinical colorectal cancer is minimal.

Epidemiological studies have indicated that consumption of broiled, fried, barbequed or smoked meats may increase the risk of CRC (29-31), although these findings were not consistent. Augustsson et al (31) observed an inverse association between high intake of heterocyclic aromatic amines (HAA) and the risk of colon and rectal cancer. However, Gerhardsson de Verdier et al (29) observed an increased association for total meat intake as well as frequent consumption of brown gravy and a preference for a heavily browned meat surface and the risk of CRC. The relative risks (RR) were higher for rectal than for colon cancer. High temperature cooking of meat proteins generates HAA, whereas the process of grilling and smoking of meat forms polycyclic aromatic amines (PAH) as a result of fat dropping on open flames. Animal and in vitro studies have shown that HAA-DNAadducts can cause transitions and transversions, as observed in the K-ras oncogene. However, results from animal experiments are not entirely consistent (14). In humans, a higher prevalence of $\mathrm{G}>\mathrm{T}$ transversions in the $\mathrm{K}$-ras gene was observed in 37 colorectal tumours from Yugoslavia which the authors explain as possibly being due to the extensive use of barbequed and smoked meat throughout the year in Yugoslavia (11). Unfortunately. information on meat preparation was not collected at baseline in the current study. An increased association was found for high consumption of beef and overall colon cancer risk. When taking into account the presence or absence of a $K$-ras mutation, this association appeared to be confined to colon tumours with a wild type $K$-ras gene. A high consumption of pork, however, appeared to be inversely associated with both colon and rectal cancer with a wild type K-ras gene. In addition, consumption of beef and pork was not associated with the risk of colon and rectal tumours harbouring $K$-ras point mutations. Consequently, consumption of beef and pork seems to be of importance for colon and rectal tumours with a $K$-ras wild type genotype and may, exert its action through another pathway than the $K$-ras signalling route. The inverse associations for high consumption of pork can not readily be explained and need replication in other studies. In general, multiple comparisons were performed and, therefore, it could be that some of the observed associations are chance findings. Therefore, caution is warranted in interpreting the results.

It is hypothesized that fat content of meat could influence CRC risk by increasing the excretion of bile acids (3). The products of the bile acid excretion may act as tumour promoters by a non-specific effect that increases cell proliferation in the mucosa layer (3). However, total fat intake (32) as well as total fresh meat consumption were not associated with overall colon and rectal cancer risk nor with $K$-ras mutation status. In the previous study (32), only $\omega-6$ polyunsaturated fat (PUFA) was observed to be associated with specific $K$-ras mutations, however, this type of fat is not predominantly present in meat.

In the current study, no clear association was observed for daily consumption of meat products and overall colon and rectal cancer risk. When the absence or presence of $K$-ras mutations was taken into account in the current study, a high intake of meat products was found to be positively associated with colon tumours with a wild type $K$-ras gene. As for high consumption of beef, the high consumption of meat products may be positively associated with colon cancer risk, although through another pathway than the $K$-ras signalling route. In addition, subgroup analysis of specific point mutations in the $K$-ras gene showed that high consumption of meat products is positively associated with rectal tumours harbouring a $G>A$ transition. This is in line with the biological evidence obtained in animal studies (33) and 
humans (13). A plausible explanation is the action of alkylating agents, such as nitrosamines. Nitrosamines and their precursors are compounds observed in red and processed meat (34) or can be endogenously formed (35). Alkylating DNA agents like nitrosamines could generate $\mathrm{O}^{6}$-methylguanines and these have been detected in human colonic tissue (36). N-nitroso compounds could also induce $\mathrm{G}>\mathrm{A}$ transitions in codons 12 or 13 of the $K$-ras gene of rat colon carcinomas $(33,37,38)$ or in human colonic tissue (35). Why the association in our study is confined to the rectum and is not observed for the colon remains unclear. A plausible explanation for differences in tumour site could be due to the duration of contact with, and the concentration of, the potential dietary carcinogens like nitrosamines. Possibly, the lower transit time of stool in the rectum as compared to the colon leads to an increased exposure time for the rectum. However, more aetiological insight in the underlying mechanisms is required to clarify this issue.

Our results suggest that total fresh meat and fish are not associated with colon or rectal cancer risk or with the K-ras mutation status of these cancer types. A high consumption of beef, pork and meat products is of importance, in particular for the aetiology of colon tumours without a $K$-ras mutation. Therefore, beef, pork and meat products may exert their actions in colon cancer through another pathway, which does not depend on the K-ras mutation status. Regarding rectal cancer, a high consumption of meat products appears to be a risk factor for $\mathrm{G}>\mathrm{A}$ transitions in the $K$-ras gene.

In conclusion, although neither total fresh meat nor fish appeared to contribute to the risk of colon and rectal cancer, the consumption of beef, pork and meat products is differentially associated with colon and rectal cancer risk depending on $K$-ras mutation status.

\section{REFERENCES}

1. Potter JD. (1996) Nutrition and colorectal cancer. Cancer Causes Control, 7(1), 127-46.

2. Giovannucci E, Willett WC. (1994) Dietary factors and risk of colon cancer. Ann Med, 26(6), 443-52.

3. Norat T, Lukanova A, Ferrari P, Riboli E. (2002) Meat consumption and colorectal cancer risk: Dose-response meta- analysis of epidemiological studies. Int $J$ Cancer, 98(2), 241-56.

4. Hill MJ, Morson BC, Bussey HJ. (1978) Aetiology of adenoma--carcinoma sequence in large bowel. Lancet, 1(8058), 245-7.

5. Vogelstein B, Fearon ER, Hamilton SR, et al. (1988) Genetic alterations during colorectal-tumor development. N Engl J Med, 319(9), 525-32.

6. Fearon ER, Vogelstein B. (1990) A genetic model for colorectal tumorigenesis. Cell, 61(5), 759-67.

7. Bos JL, Fearon ER, Hamilton SR, et al. (1987) Prevalence of ras gene mutations in human colorectal cancers. Nature, 327(6120), 293-7.

8. Breivik J, Meling GI, Spurkland A, Rognum TO, Gaudernack G. (1994) K-ras mutation in colorectal cancer: relations to patient age, sex and tumour location. $\mathrm{Br} J$ Cancer, 69(2), 367-71.

9. Brink M, De Goeij AF, Weijenberg MP, et al. (2003) K-ras oncogene mutations in sporadic colorectal cancer in The Netherlands Cohort Study. Carcinogenesis, 24(4), 703-710.

10. Martinez-Garza SG, Nunez-Salazar A, Calderon-Garciduenas AL, Bosques-Padilla FJ, Niderhauser-Garcia A, Barrera-Saldana HA. (1999) Frequency and clinicopathology associations of $\mathrm{K}$-ras mutations in colorectal cancer in a northeast Mexican population. Dig Dis, 17(4), 225-9. 
11. Urosevic N, Krtolica K, Skaro-Milic A, Knezevic-Usaj S, Dujic A. (1993) Prevalence of G-to-T transversions among K-ras oncogene mutations in human colorectal tumors in Yugoslavia. Int J Cancer, 54(2), 249-54.

12. Bingham SA, Pignatelli B, Pollock JR, et al. (1996) Does increased endogenous formation of $\mathrm{N}$-nitroso compounds in the human colon explain the association between red meat and colon cancer? Carcinogenesis, 17(3), 515-23.

13. Hughes R, Cross AJ, Pollock JR, Bingham S. (2001) Dose-dependent effect of dietary meat on endogenous colonic N- nitrosation. Carcinogenesis, 22(1), 199-202.

14. Vineis P. McMichael A. (1996) Interplay between heterocyclic amines in cooked meat and metabolic phenotype in the etiology of colon cancer. Cancer Causes Control, 7(4), 479-86.

15. van den Brandt PA, Goldbohm RA, van 't Veer P, Volovics A, Hermus RJ, Sturmans F, (1990) A large-scale prospective cohort study on diet and cancer in The Netherlands. $J$ Clin Epidemiol, 43(3), 285-95.

16. van den Brandt PA, Schouten LJ, Goldbohm RA, Dorant E, Hunen PM. (1990) Development of a record linkage protocol for use in the Dutch Cancer Registry for Epidemiological Research. Int J Epidemiol, 19(3), 553-8.

17. Schouten LJ, Jager JJ, van den Brandt PA. (1993) Quality of cancer registry data: a comparison of data provided by clinicians with those of registration personnel. $\mathrm{Br} \mathrm{J}$ Cancer, 68(5), 974-7.

18. Schouten LJ, Straatman H, Kiemeney LA, Gimbrere CH, Verbeek AL. (1994) The capture-recapture method for estimation of cancer registry completeness: a useful tool? Int J Epidemiol, 23(6), 1111-6.

19. van der Sanden GA, Coebergh JW, Schouten LJ, Visser O, van Leeuwen FE. (1995) Cancer incidence in The Netherlands in 1989 and 1990: first results of the nationwide Netherlands cancer registry. Coordinating Committee for Regional Cancer Registries. Eur J Cancer, 31A(11), 1822-9.

20. Nevo table. (1986) Dutch food composition table 1986-1987.

21. Goldbohm RA, van den Brandt PA, Brants HA, et al. (1994) Validation of a dietary questionnaire used in a large-scale prospective cohort study on diet and cancer. Eur $J$ Clin Nutr, 48(4), 253-65.

22. Barlow WE, Ichikawa L, Rosner D, Izumi S. (1999) Analysis of case-cohort designs. J Clin Epidemiol, 52(12), 1165-72.

23. Schoenfeld D. (1982) Partial residuals for the proportional hazards regression model. Biometrika, 69, 239-241.

24. Goldbohm RA, van den Brandt PA, van 't Veer P, et al. (1994) A prospective cohort study on the relation between meat consumption and the risk of colon cancer. Cancer Res, 54(3), 718-23.

25. Slattery ML, Curtin K, Anderson K, et al. (2000) Associations between dietary intake and Ki-ras mutations in colon tumors: a population-based study. Cancer Res, 60(24), 6935-41.

26. Voskuil DW. (1999) Diet-gene interactions in sporadic and hereditary colorectal carcinogenesis; epidemiological perspectives, Thesis.

27. Kampman E, Voskuil DW, van Kraats AA, et al. (2000) Animal products and K-ras codon 12 and 13 mutations in colon carcinomas. Carcinogenesis, 21(2), 307-9.

28. O'Brien H, Matthew JA, Gee JM, et al. (2000) K-ras mutations, rectal crypt cells proliferation, and meat consumption in patients with left-sided colorectal carcinoma. Eur $J$ Cancer Prev, 9(1), 41-7.

29. Gerhardsson de Verdier M, Hagman U, Peters RK, Steineck G, Overvik E. (1991) Meat, cooking methods and colorectal cancer: a case-referent study in Stockholm. Int $J$ Cancer, 49(4), 520-5. 
30. Kampman E, Slattery ML, Bigler J, et al. (1999) Meat consumption, genetic susceptibility, and colon cancer risk: a United States multicenter case-control study. Cancer Epidemiol Biomarkers Prev, 8(1), 15-24.

31. Augustsson K, Skog K, Jagerstad M, Dickman PW, Steineck G. (1999) Dietary heterocyclic amines and cancer of the colon, rectum, bladder, and kidney: a populationbased study [see comments]. Lancet, 353(9154), 703-7.

32. Brink M, Weijenberg MP, de Goeij AF, Schouten LJ, Koedijk FD, Roemen GM, Lentjes $\mathrm{MH}$, de Bruîne AP, Goldbohm RA and van den Brandt, PA. (2004) Fat and $K$-ras mutations in sporadic colorectal cancer in The Netherlands Cohort Study. Carcinogenesis, 25(9), 1619-1628.

33. Jacoby RF, Alexander RJ, Raicht RF, Brasitus TA. (1992) K-ras oncogene mutations in rat colon tumors induced by $\mathrm{N}$-methyl- $\mathrm{N}$ - nitrosourea. Carcinogenesis, 13(1), 45-9.

34. Mirvish SS, Haorah J, Zhou L, Clapper ML, Harrison KL, Povey AC. (2002) Total Nnitroso compounds and their precursors in hot dogs and in the gastrointestinal tract and feces of rats and mice: possible etiologic agents for colon cancer. $J$ Nutr, 132(11 Suppl), 3526S-3529S.

35. Bingham SA, Hughes R, Cross AJ. (2002) Effect of white versus red meat on endogenous $\mathrm{N}$-nitrosation in the human colon and further evidence of a dose response. J Nutr, 132(11 Suppl), 3522S-3525S.

36. Hall CN, Badawi AF, O'Connor PJ, Saffhill R. (1991) The detection of alkylation damage in the DNA of human gastrointestinal tissues. $\mathrm{Br} J$ Cancer, 64(1), 59-63.

37. Zarbl H, Sukumar S, Arthur AV, Martin-Zanca D, Barbacid M. (1985) Direct mutagenesis of Ha-ras-1 oncogenes by $\mathrm{N}$-nitroso- $\mathrm{N}$-methylurea during initiation of mammary carcinogenesis in rats. Nature, 315(6018), 382-5.

38. Topal MD. (1988) DNA repair, oncogenes and carcinogenesis. Carcinogenesis, 9(5), 691-6. 
Fat and $K$-ras mutations in sporadic colon and rectal cancer in The Netherlands Cohort Study 


\title{
Fat and $K$-ras mutations in sporadic colon and rectal cancer in The Netherlands Cohort Study
}

\author{
Mirian Brink ${ }^{1}$ \\ Matty P Weijenberg ${ }^{1}$ \\ Anton FPM de Goeij ${ }^{2}$ \\ Leo J Schouten ${ }^{1}$ \\ Femke DH Koedijk ${ }^{1}$ \\ Guido MJM Roemen ${ }^{3}$ \\ Marjolein HFM Lentjes ${ }^{3}$ \\ Adriaan $\mathrm{P}$ de Bruīne ${ }^{2}$ \\ R Alexandra Goldbohm ${ }^{4}$ \\ Piet A van den Brandt ${ }^{1}$
}

' Nutrition and Toxicology Research Institute Maastricht (NUTRIM), Dept. of Epidemiology,

Maastricht University, The Netherlands

${ }^{2}$ Research Institute Growth and Development (GROW), Dept. of Pathology, Maastricht University, The Netherlands

${ }^{3}$ NUTRIM, Dept. of Pathology, Maastricht University, The Netherlands

${ }^{4}$ TNO Nutrition and Food Research, Zeist, The Netherlands 


\begin{abstract}
Associations between dietary intake of various fats and specific $\mathrm{K}$-ras mutations in colon and rectal cancer were investigated within the framework of The Netherlands Cohort Study on diet and cancer.

After 7.3 years of follow-up and with exclusion of the first 2.3 years, 448 colon and 160 rectal cancer patients and 2948 subcohort members (55-69 years at baseline) were available for data-analyses. Mutation analysis of the $K$-ras gene was performed on all archival colon and rectal adenocarcinoma specimens. Case-cohort analyses were used to compute adjusted incidence rate ratios (RR) and $95 \%$ confidence intervals $(\mathrm{CI})$ for colon and rectal cancer cases and for $K$-ras mutation status subgroups.

Intake of total, saturated and monounsaturated fat was not significantly associated with colon or rectal cancer. High intake of dietary polyunsaturated fat (PUFA) and, specifically, linoleic acid is associated with an increased risk of mutated $K$-ras colon tumours. The RRs for one standard deviation of increase of PUFA and linoleic acid were $1.21(95 \% \mathrm{Cl} 1.05$ $1.41)$ and $1.22(95 \% \mathrm{Cl} 1.05-1.42)$, respectively and similar associations were observed for both $\mathrm{G}>\mathrm{A}$ transitions and $\mathrm{G}>\mathrm{T}$ or $\mathrm{G}>\mathrm{C}$ transversions in the colon. In contrast, no significant associations were observed with rectal cancer risk, overall or with specific $K$-ras mutation status.

A high intake of PUFA, in particular linoleic acid, may be an important dietary risk factor for $K$-ras mutated colon tumours, possibly by generating $G>A$ transitions or $G>T$ or $G>C$ transversions in the $K$-ras oncogene.
\end{abstract}




\section{INTRODUCTION}

The current epidemiological evidence for the association of total fat and specific fatty acids with colorectal cancer (CRC) risk is controversial $(1,2)$. The observed inconsistencies could, in part, be due to the heterogeneity of the colon and rectal cancer endpoint that is studied. Associations may become more apparent when the molecular events involved in colorectal carcinogenesis are taken into account.

The majority of colon and rectal tumours develops from small adenomatous polyps through a well-defined sequence of cytological and morphological changes (3), a process that is associated with the acquisition of somatic mutations $(4,5)$. A genetic alteration that occurs in adenomas $(10 \%)$ as well as carcinomas $(40 \%)$ in colon and rectal cancer, is the oncogenic activation of the $K$-ras gene by mutations. Activating mutations are mainly found in codons 12 and $13(4,6-8)$. The most frequently observed types of point mutations are $G>A$ transitions $(8,9)$, and $G>T$ and $G>C$ transversions (10).

The link between fat intake and the pattern of mutations in human colon and rectal cancer is not clear. Only a few epidemiological studies have been conducted up to date on the association between the intake of fat and $K$-ras mutation status (11-14) and results are inconsistent. Experimental studies suggest that peroxidation of $\omega-6$ poly-unsaturated fats (PUFA) could lead to the accumulation of by-products like malondialdehyde (MDA) and 4-hydroxynonenal (4-HNE). These compounds could react with DNA to form adducts, mainly the pyrimidopurinone adduct of deoxyguanosine $\left(\mathrm{M}_{1} \mathrm{G}\right)$ (15-17). The presence of the $\mathrm{M}_{1} \mathrm{G}$-adducts resulted predominantly in $\mathrm{G}>\mathrm{A}$ and $\mathrm{G}>\mathrm{T}$, with very few $\mathrm{G}>\mathrm{C}$ transversions in bacteria $(16,18,19)$.

Consequently, exposures to specific dietary fat and fatty acids could contribute to the heterogeneity of acquired genetic alterations in the $K$-ras oncogene observed in colon and rectal tumours. Associations between dietary intakes of fat and specific fatty acids and the risk of specific point mutations in the $K$-ras oncogene in patients with colon and rectal cancer were studied within the framework of the Netherlands Cohort Study on diet and cancer (NLCS).

\section{MATERIALS AND METHODS}

\section{Study Population}

The participants in this study are incident, colon and rectal cancer cases and subcohort members from the NLCS, which has been described in detail elsewhere (20). Briefly, the study was initiated in 1986 and includes 58,279 men and 62,573 women, aged 55-69 years old at baseline, who originated from 204 Dutch municipalities with computerized population registries. A self-administered questionnaire on diet and other risk factors for cancer was completed at baseline. The entire cohort is being monitored for cancer occurrence by annual record linkage to the Netherlands Cancer Registry (NCR, nine cancer registries in the Netherlands) and to PALGA, a nationwide network and registry of histo- and cytopathology (www.palga.nl) (21). In the municipalities included in the NLCS, the NCR and PALGA. together, have nearly $100 \%$ coverage since the start of the study (22-25). PALGA also provides necessary information on the identification of the pathology laboratory location of the storage of paraffin-embedded blocks of the eligible CRC patients. Accumulation of persontime in the cohort has been estimated through biennial vital status follow-up of a subcohort of 3,500 men and women who were randomly selected after baseline exposure measurement (21). Cases with prevalent cancer other than non-melanoma skin cancer were excluded from the subcohort, which left 3,346 men and women for analysis. 
Table 1 Nutrient intake (mean \pm SD) and other characteristics of the study population at baseline

\begin{tabular}{|c|c|c|c|}
\hline & \multirow[t]{2}{*}{ Subcohort } & \multicolumn{2}{|c|}{ Colon cancer } \\
\hline & & Wild type K-ras & Mutated K-ras \\
\hline N & 2948 & 297 & 151 \\
\hline Sex (\% Men) & 48.2 & 51.5 & 58.9 \\
\hline Age (y) & $61.3 \pm 4.2$ & $62.7 \pm 4.0$ & $63.8 \pm 4.1$ \\
\hline \multicolumn{4}{|l|}{ Fat variables* } \\
\hline Total fat $(g / d)$ & $83.8 \pm 15.8$ & $84.3 \pm 15.4$ & $86.7 \pm 14.8$ \\
\hline Saturated lat $(g / d)$ & $33.2 \pm 7.5$ & $33.5 \pm 6.9$ & $33.6 \pm 6.7$ \\
\hline MUFA $(g / d)^{* *}$ & $31.4 \pm 7.0$ & $31.7 \pm 6.5$ & $32.1 \pm 6.9$ \\
\hline PUFA $(g / d)^{* \cdots *}$ & $17.3 \pm 7.5$ & $17.2 \pm 7.3$ & $19.3 \pm 7.6$ \\
\hline Linolenic acid (g/day) & $1.3 \pm 0.6$ & $16.1 \pm 7.3$ & $1.3 \pm 0.6$ \\
\hline Linoleic acid (gday) & $16.0 \pm 7.5$ & $1.2 \pm 0.5$ & $18.0 \pm 7.7$ \\
\hline \multicolumn{4}{|l|}{ Other dietary factors } \\
\hline Fiber $(g / d)$ & $27.0 \pm 8.2$ & $26.7 \pm 7.6$ & $27.7 \pm 8.8$ \\
\hline Alcohol $(g / d)$ & $10.1 \pm 14.1$ & $11.0 \pm 15.4$ & $10.8 \pm 14.2$ \\
\hline Fruit $(g / d)$ & $177.0 \pm 118.0$ & $172.7 \pm 123.7$ & $176.9 \pm 122.2$ \\
\hline Vegetable ( $g / d)$ & $193.8 \pm 82.2$ & $183.3 \pm 78.2$ & $198.0 \pm 87.0$ \\
\hline Energy (kcal/d) & $1919.1 \pm 517.1$ & $1916.5 \pm 494.4$ & $1902.7 \pm 472.9$ \\
\hline \multicolumn{4}{|l|}{ Other characteristics } \\
\hline Ql $\left(\mathrm{kg} / \mathrm{m}^{2}\right)$ & $25.1 \pm 3.1$ & $25.5 \pm 3.2$ & $25.8 \pm 3.3$ \\
\hline Family historys (\% Yes) & 5.7 & 13.5 & 9.3 \\
\hline \multicolumn{4}{|l|}{ Smoker $(\%)$} \\
\hline Never & 36.9 & 36.7 & 37.1 \\
\hline Ex smoker & 35.2 & 43.1 & 46.4 \\
\hline Current smoker & 27.8 & 20.2 & 16.6 \\
\hline \multicolumn{4}{|l|}{ Physical activity (\%) } \\
\hline <30 minutes/day & 20.1 & 19.7 & 20.3 \\
\hline 30-60 minutes/day & 32.2 & 33.7 & 32.4 \\
\hline $60-90$ minutes/day & 31.1 & 29.6 & 29.1 \\
\hline$>90$ minutes/dav & 154 & 120 & $18 ?$ \\
\hline \multicolumn{4}{|c|}{$\begin{array}{l}\text { comparing cases with at least one } K \text {-ras mutation to cases without a K-ras mutation } \\
\text { adjusted for energy by the residual method (45) } \\
\text { monounsaturated fat }\end{array}$} \\
\hline
\end{tabular}

The first 2.3 years of follow up were excluded due to incomplete coverage of PALGA alone in some of the municipalities included in the NLCS. Within this period, 83 subcohort members were either deceased or diagnosed with cancer other than non-melanoma skin cancer, leaving 3,263 men and women for analysis. From 1989 till 1994, 929 incident cases with histologically confirmed CRC where observed of whom 819 could also be linked to a PALGA report of the lesion. The PALGA database was used to identify and locate tumour tissue in Dutch pathology laboratories. CRC was classified according to site as follows: colon i.e. cecum through sigmoid colon (ICD-O-1 codes: 153.0, 153.1, 153.2, 153.3, 153.4, 153.5, 153.6, 153.7, 153.8, 153.9), rectosigmoid (ICD-O-1 code 154.0) and rectum (ICD-O-1 code 154.1). Information about age at baseline, sex and family history of CRC (at baseline) was retrieved from the NLCS database.

\section{Tissue Samples}

This study is based on data of gene mutation analysis from CRC patients, described in detail elsewhere (8). Briefly, tumour material of all CRC patients was collected after approval by the Medical Ethics Committees of Maastricht University, the NCR and PALGA. Subsequently, all pathology laboratories in The Netherlands agreed to make relevant tissue samples available upon request from PALGA. Tissue samples of the 819 cases were distributed among 54 pathology laboratories throughout The Netherlands. Tumour tissue 
Table 1 Continued

\begin{tabular}{|c|c|c|c|}
\hline \multirow[b]{2}{*}{ p-value } & \multicolumn{2}{|c|}{ Rectal cancer } & \multirow[b]{2}{*}{ p-value } \\
\hline & Wild type K-ras & Mutated $K$-ras & \\
\hline & 93 & 67 & \\
\hline $\begin{array}{l}0.14 \\
0.006\end{array}$ & $\begin{array}{l}72.0 \\
62.6 \pm 4.1\end{array}$ & $\begin{array}{l}55.2 \\
62.2 \pm 4.0\end{array}$ & $\begin{array}{l}0.03 \\
0.50\end{array}$ \\
\hline $\begin{array}{l}0.12 \\
0.89 \\
0.54 \\
0.006 \\
0.18 \\
0.009\end{array}$ & $\begin{array}{l}86.7 \pm 15.3 \\
34.1 \pm 6.8 \\
32.2 \pm 6.6 \\
18.5 \pm 8.9 \\
1.2 \pm 0.6 \\
17.4 \pm 8.9\end{array}$ & $\begin{array}{l}86.0 \pm 14.2 \\
34.3 \pm 6.9 \\
32.5 \pm 5.6 \\
17.5 \pm 8.2 \\
1.3 \pm 0.5 \\
16.2 \pm 8.3\end{array}$ & $\begin{array}{l}0.76 \\
0.87 \\
0.80 \\
0.46 \\
0.41 \\
0.41\end{array}$ \\
\hline $\begin{array}{l}0.02 \\
0.59 \\
0.73 \\
0.07 \\
0.78\end{array}$ & $\begin{array}{l}27.8 \pm 8.0 \\
13.8 \pm 17.6 \\
184.3 \pm 145.8 \\
192.9 \pm 72.4 \\
2027.3 \pm 517.4\end{array}$ & $\begin{array}{l}27.6 \pm 7.8 \\
11.2 \pm 12.2 \\
180.7 \pm 129.9 \\
188.0 \pm 110.6 \\
1997.0 \pm 449.1\end{array}$ & $\begin{array}{l}0.87 \\
0.30 \\
0.87 \\
0.74 \\
0.70\end{array}$ \\
\hline $\begin{array}{l}0.42 \\
0.20\end{array}$ & $\begin{array}{l}24.9 \pm 2.8 \\
9.7\end{array}$ & $\begin{array}{l}25.5 \pm 2.9 \\
11.9\end{array}$ & $\begin{array}{l}0.20 \\
0.66\end{array}$ \\
\hline 0.62 & $\begin{array}{l}25.8 \\
41.9 \\
32.3\end{array}$ & $\begin{array}{l}34.3 \\
43.3 \\
22.4\end{array}$ & 0.31 \\
\hline 0.98 & $\begin{array}{l}18.5 \\
27.2 \\
32.6 \\
21.7\end{array}$ & $\begin{array}{l}22.7 \\
27.3 \\
34.8 \\
15.2\end{array}$ & 0.73 \\
\hline
\end{tabular}

specimens collection started in August 1999 and was completed in December 2001. The loss to follow-up of tissue samples of cases amounted to $5 \%$. Tissue samples from nine patients reistered in one pathology laboratory could not be retrieved due to administrative inconsistencies, leaving 810 tissue samples for collection. For 34 cases, paraffin-embedded material was not available in the archives of pathology laboratories, leaving 776 cases for the determination of the $K$-ras mutation status. For 39 cases $(5 \%)$, the $K$-ras mutation status could not be determined, i.e. for 20 cases only normal colonic mucosa was available, 10 cases were revised with an benign adenoma (AdB) instead of an adenocarcinoma, for six cases the yield of DNA was not sufficient enough to determine $K$-ras mutation status and for three cases the available tissue did not include malignant CRC tissue. Finally, tumour material from 737 incident colorectal adenocarcinoma cases was available of whom 476 were colon cancer cases, 85 were rectosigmoid cancer cases and 176 were rectal cancer cases. Statistical analyses were performed separately for colon and rectal cancer as differences in the aetiology of colon and rectal cancer have been reported (1). Since the rectosigmoid can be considered as a clinically applied term rather than an atomically defined transitional zone between the colon and rectum, patients with a rectosigmoid tumour were excluded from data analyses. Moreover, the number of patients with a rectosigmoid tumour was too small for adequate stratified analyses (8).

\section{Detection of $\boldsymbol{K}$-ras Mutations}

Mutation analysis of the exon 1 fragment of the $K$-ras oncogene, spanning codons 8-29, was performed on archival colorectal adenocarcinoma specimens of all 737 CRC patients using macrodissection, nested Polymerase Chain Reaction (PCR) and direct sequencing of 
purified fragments, which has been described in detail elsewhere (8). The method of mutation detection was validated by the confirmation of reported $K$-ras status in CRC cell lines and a good correlation between fresh-frozen and routinely-fixed, paraffin-embedded tissue. The detection limit was $5 \%$ mutated DNA. Duplo analyses revealed a good reproducibility ( $88 \%$ ) (8). Evaluation of mutation analysis and data entry was independently performed by two observers (GR and ML).

\section{The Food Frequency Questionnaire}

The dietary section of the questionnaire was a 150-item semi-quantitative food frequency questionnaire, which concentrated on habitual consumption of food and beverages during the year preceding the start of the study. Daily mean nutrient intakes were calculated using the computerized Dutch food composition table (26), by cumulating the multiplied frequencies and portion sizes of all food items with their tabulated nutrient contents. The questionnaire was validated against a 9-day diet record (27). Crude and energy-gender-adjusted (in parentheses) correlation coefficients were $0.72(0.52)$ for total fat, $0.73(0.58)$ for saturated fat and $0.73(0.75)$ for PUFA (27). For energy intake the correlation coefficient was 0.74 . On average, the questionnaire covered $91 \%$ of the record intake explaining part of the underestimation of energy intake from the questionnaire data (as presented in table 1). Questionnaire data were key-entered twice and processed for all incident cases in the cohort and for all subcohort members in a manner blinded with respect to case/subcohort status. This was done in order to minimise observer bias in coding and interpretation of the data.

For 257 subjects (28 incident colon adenocarcinoma cases, 16 incident rectal adenocarcinoma cases and 215 subcohort members, two subcohort members were also colon or rectal cancer cases), dietary data were incomplete or inconsistent, and they were excluded from the analyses. These subjects either 1) left 60 or more (out of 150) questionnaire items blank and ate fewer than 35 items at least once per month and/or 2) left one or more item blocks (groups of items, e.g., beverages) blank. Additional details are given elsewhere (27). Hence, 608 colon and rectal cancer cases and 3048 subcohort members were available for data analyses.

Intake of specific fatty acids was based on a food composition database with specific fatty acids derived from the TRANSFAIR study (28). For this database, the hundred foods that contributed most to fat intake in the Dutch dietary pattern were sampled and analysed as methyl esters of the fatty acids present in the foods. In the database, total fat includes triglycerides and other lipids such as phospholipids and sterols. The percentage of triglycerides in total fat is assumed to be on average 93 percent, but varies across food sources. Daily intakes of total fat (g/day), saturated fat (g/day), monounsaturated fat (MUFA) (g/day), PUFA (g/day), and linolenic acid ( $g /$ day) and linoleic acid ( $g /$ day) as main constituents of PUFA, were used as exposure variables. Linolenic and linoleic acid were used as the most abundant sources of $\omega-3$ PUFA and $\omega-6$ PUFA. For data-analyses, quartiles of the intake of fat and fatty acids were computed based on the distribution of subcohort members. Daily intake of dietary fiber ( $g /$ day), alcohol $(g /$ day), fruit $(g /$ day), vegetables ( $\mathrm{g} /$ day) and total energy (kcal/day) and age at baseline (years), sex (men/women), Body Mass Index (Ql; kg/m²), physical activity ( $<30 \mathrm{~min} / \mathrm{d}, 30-60 \mathrm{~min} / \mathrm{d}, 60-90$ $\mathrm{min} / \mathrm{d},>90 \mathrm{~min} / \mathrm{d}$ ), family history of CRC (yes/no) and smoking status (never/ex/current) were regarded as potential confounders.

\section{Statistical Analysis}

The overall frequency of $K$-ras mutations as well as the type of mutation was computed for all colon and rectal cancer cases as described elsewhere (8). Fat intake was adjusted for energy by the residual method (29). Mean values of the continuous variables age at 
baseline (years), intake of total fat, saturated fat, MUFA, PUFA, linolenic acid, linoleic acid, dietary fiber, alcohol, fruit, vegetables and total energy and QI were evaluated for subcohort members and colon and rectal cancer cases with wild type and mutated $K$-ras gene. Distributions in the categorical variables sex, family history of CRC, smoking status and physical activity were evaluated for subcohort members and colon and rectal cancer patients with wild type and mutated $K$-ras gene. Differences in mean values of the continuous variables and the distributions in categorical variables between patients with wild type and mutated $K$-ras tumours were tested with the Student T-test and $\mathrm{X}^{2}$-test, respectively, using the statistical software package SPSS (version 9).

Incidence rate ratios (RR) and corresponding $95 \%$ confidence intervals $(\mathrm{CI})$ for colon and rectal cancer cases with wild type or mutated $K$-ras gene tumours were estimated according to intakes of quartiles (with the lower quartile of intake regarded as the reference group) and of one standard deviation (SD) of increase of intake of total fat, saturated fat, MUFA, PUFA, linolenic acid and linoleic acid using Cox proportional hazards models with the STATA statistical software package (intercooled STATA, version 7). The total personyears at risk, estimated from the subcohort, were used in the analyses (27). Standard errors were estimated using the robust Huber-White sandwich estimator to account for additional variance introduced by sampling from the cohort. This method is equivalent to the variancecovariance estimator as presented by Barlow (30). The proportional hazards assumption was tested using the scaled Schoenfeld residuals (31). Using the backwards stepwise procedure, all confounders were tested in the overall colon and rectal cancer models separately. Interactions between fat and specific fatty acid intake and sex were tested for colon and rectal cancer separately and never found to be statistically significant. Therefore, results for men and women are presented together. Finally, age at baseline, sex, family history of CRC, smoking status, QI and the intake of energy were confounders for either one or both of the models and were therefore included as covariates for all models to be tested. Since 100 subcohort members had missing values for QI, results in the tables will be presented for 2948 subcohort members. For each analysis, trends were evaluated with the Wald test by fitting ordinal exposure variables (quartiles of intake) as continuous terms.

\section{RESULTS}

The overall frequency and spectrum of mutations in the $K$-ras gene have been presented in detail elsewhere (8). In brief, a total of 227 mutations was found in 218 (36\%) out of 608 colon and rectal cancer patients. The most frequently observed mutations are the G>A transitions (54\%), G>T transversions (33\%) and $\mathrm{G}>\mathrm{C}$ transversions $(7 \%)$. The observed frequencies of the point mutation are similar to the frequencies of the 737 CRC cases, including rectosigmoid cancer cases, for whom $K$-ras status was determined (8).

Table 1 shows various types of fat intake and other baseline characteristics of the study population. Colon and rectal cancer cases were more often men, were older, more frequently reported a family history of CRC and had a higher daily alcohol intake as compared to the subcohort. Colon cancer cases with a mutated $K$-ras tumour were significantly older, had higher daily intakes of PUFA, linoleic acid, fibers and vegetables than colon cancer cases with a wild type $K$-ras tumour. There were no statistically significant differences between colon cancer cases with a wild type $K$-ras tumour and a mutated $K$-ras tumour in dietary intakes of total fat, saturated fat, MUFA, linolenic acid and other factors presented in table 1 . Rectal cancer cases with a mutated $K$-ras tumour were less frequently men as compared to rectal cancer cases with a wild type $K$-ras tumour. No statistically significant differences between rectal cancer cases with mutated $K$-ras tumours and wild 
Table 2 Incidence rate ratios (RR) and 95\% confidence intervals $(\mathrm{Cl})$ for colon $(\mathrm{N}=448)$ and rectal cancer patients $(\mathrm{N}=160)$ according to the intake of total fat and specific fatty acids

\begin{tabular}{|c|c|c|c|c|c|c|c|}
\hline & \multicolumn{5}{|c|}{ Quartile of intake } & \multirow{2}{*}{$\begin{array}{l}\text { RR }(95 \% \mathrm{CI}) \text { for } \\
\text { one SD increase } \\
\text { in intake' }\end{array}$} \\
\hline & & 11 & 2 & 3 & 4 & $\begin{array}{l}\text { Pfor } \\
\text { trend }\end{array}$ & \\
\hline $\begin{array}{l}\text { Total fat } \\
\text { Median intake ( } \\
\text { men } \\
\text { Women } \\
\text { colon cancer ca } \\
\text { rectum cancer c } \\
\text { personyears } \\
\text { RR }(95 \% \mathrm{CI})^{2}\end{array}$ & $\begin{array}{l}\text { Jd) } \\
\text { ses } \\
\text { ases } \\
\text { colon } \\
\text { rectum }\end{array}$ & $\begin{array}{l}78.1 \\
63.0 \\
113 \\
43 \\
3657 \\
1.00 \\
1.00\end{array}$ & $\begin{array}{l}90.3 \\
71.5 \\
126 \\
42 \\
3675 \\
1.09(0.82-1.43) \\
0.96(0.62-1.49)\end{array}$ & $\begin{array}{l}98.5 \\
77.6 \\
95 \\
34 \\
3741 \\
0.80(0.60-1.08) \\
0.75(0.47-1.20)\end{array}$ & $\begin{array}{l}109.1 \\
85.3 \\
114 \\
40 \\
3664 \\
0.99(0.74-1.32) \\
0.92(0.59-1.44)\end{array}$ & $\begin{array}{l}0.49 \\
0.52\end{array}$ & $\begin{array}{l}1.02(0.90-1.15) \\
0.94(0.78-1.13)\end{array}$ \\
\hline $\operatorname{RR}(95 \% \mathrm{Cl})^{3}$ & $\begin{array}{l}\text { colon } \\
\text { rectum }\end{array}$ & $\begin{array}{l}1.00 \\
1.00\end{array}$ & $\begin{array}{l}1.09(0.82-1.44) \\
0.89(0.56-1.39)\end{array}$ & $\begin{array}{l}0.74(0.55-1.01) \\
0.74(0.46-1.19)\end{array}$ & $\begin{array}{l}0.95(0.71-1.27) \\
0.86(0.55-1.36)\end{array}$ & $\begin{array}{l}0.28 \\
0.41\end{array}$ & $\begin{array}{l}1.00(0.88-1.13) \\
0.91(0.76-1.09)\end{array}$ \\
\hline $\begin{array}{l}\text { Saturated fat } \\
\text { Median intake ( } \\
\text { men } \\
\text { Women } \\
\text { colon cancer ca } \\
\text { rectum cancer c } \\
\text { personyears } \\
\text { RR }(95 \% \mathrm{Cl})^{2}\end{array}$ & $\begin{array}{l}\text { /d) } \\
\text { ses } \\
\text { ases } \\
\text { colon } \\
\text { rectum }\end{array}$ & $\begin{array}{l}28.9 \\
23.9 \\
101 \\
43 \\
3645 \\
1.00 \\
1.00\end{array}$ & $\begin{array}{l}33.7 \\
27.8 \\
123 \\
35 \\
3703 \\
1.20(0.90-1.59) \\
0.80(0.50-1.26)\end{array}$ & $\begin{array}{l}38.3 \\
31.0 \\
119 \\
46 \\
3709 \\
1.14(0.85-1.51) \\
1.04(0.67-1.59)\end{array}$ & $\begin{array}{l}45.8 \\
36.6 \\
105 \\
36 \\
3679 \\
0.97(0.72-1.30) \\
0.80(0.51-1.26)\end{array}$ & $\begin{array}{l}0.72 \\
0.58\end{array}$ & $\begin{array}{l}0.98(0.89-1.09) \\
0.97(0.83-1.15)\end{array}$ \\
\hline $\operatorname{RR}(95 \% \mathrm{CI})^{3}$ & $\begin{array}{c}\text { colon } \\
\text { rectum }\end{array}$ & $\begin{array}{l}1.00 \\
1.00\end{array}$ & $\begin{array}{l}1.19(0.88-1.60) \\
0.79(0.49-1.28)\end{array}$ & $\begin{array}{l}1.10(0.82-1.49) \\
1.02(0.65-1.59)\end{array}$ & $\begin{array}{l}0.93(0.69-1.26) \\
0.73(0.46-1.17)\end{array}$ & $\begin{array}{l}0.51 \\
0.37\end{array}$ & $\begin{array}{l}0.97(0.87-1.08) \\
0.95(0.80-1.12)\end{array}$ \\
\hline $\begin{array}{l}\text { MUFA" } \\
\text { Median intake ( } \\
\text { men } \\
\text { Women } \\
\text { colon cancer ca } \\
\text { rectum cancerc c } \\
\text { personyears } \\
\text { RR }(95 \% \mathrm{CI})^{2}\end{array}$ & $\begin{array}{l}\text { did) } \\
\text { ses } \\
\text { ases } \\
\text { colon } \\
\text { rectum }\end{array}$ & $\begin{array}{l}28.2 \\
22.4 \\
101 \\
45 \\
3660 \\
1.00 \\
1.00\end{array}$ & $\begin{array}{l}33.2 \\
26.1 \\
124 \\
34 \\
3650 \\
1.23(0.92-1.63) \\
0.76(0.48-1.21)\end{array}$ & $\begin{array}{l}36.9 \\
28.9 \\
119 \\
41 \\
3714 \\
1.17(0.88-1.56) \\
0.91(0.59-1.41)\end{array}$ & $\begin{array}{l}42.5 \\
33.0 \\
104 \\
40 \\
3713 \\
1.03(0.76-1.37) \\
0.89(0.57-1.38)\end{array}$ & $\begin{array}{l}0.97 \\
0.77\end{array}$ & $\begin{array}{l}1.00(0.89-1.11) \\
0.93(0.79-1.10)\end{array}$ \\
\hline $\operatorname{RR}(95 \% \mathrm{Cl})^{3}$ & $\begin{array}{l}\text { colon } \\
\text { rectum }\end{array}$ & $\begin{array}{l}1.00 \\
1.00\end{array}$ & $\begin{array}{l}1.19(0.89-1.60) \\
0.70(0.44-1.13)\end{array}$ & $\begin{array}{l}1.12(0.82-1.51) \\
0.91(0.57-1.44)\end{array}$ & $\begin{array}{l}0.98(0.73-1.33) \\
0.87(0.56-1.37)\end{array}$ & $\begin{array}{l}0.77 \\
0.80\end{array}$ & $\begin{array}{l}0.99(0.88-1.12) \\
0.93(0.78-1.11)\end{array}$ \\
\hline \multicolumn{8}{|c|}{ 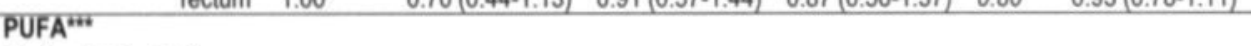 } \\
\hline $\begin{array}{l}\text { Median intake ( } \\
\text { men } \\
\text { Women } \\
\text { colon cancer ca } \\
\text { rectum cancer c } \\
\text { personyears } \\
\text { RR }(95 \% \mathrm{Cl})^{2}\end{array}$ & $\begin{array}{l}\text { gd) } \\
\text { ses } \\
\text { ases } \\
\text { colon } \\
\text { rectum }\end{array}$ & $\begin{array}{l}11.6 \\
8.8 \\
95 \\
47 \\
3656 \\
1.00 \\
1.00\end{array}$ & $\begin{array}{l}16.0 \\
12.4 \\
124 \\
33 \\
3683 \\
1.35(1.01-1.81) \\
0.71(0.45-1.13)\end{array}$ & $\begin{array}{l}20.9 \\
16.2 \\
113 \\
39 \\
3726 \\
1.23(0.92-1.66) \\
0.84(0.54-1.30)\end{array}$ & $\begin{array}{l}29.1 \\
22.5 \\
116 \\
41 \\
3667 \\
1.24(0.92-1.66) \\
0.87(0.56-1.34)\end{array}$ & $\begin{array}{l}0.26 \\
0.68\end{array}$ & $\begin{array}{l}1.05(0.96-1.16) \\
1.00(0.84-1.19)\end{array}$ \\
\hline $\operatorname{RR}(95 \% \mathrm{CI})^{3}$ & $\begin{array}{l}\text { colon } \\
\text { rectum }\end{array}$ & $\begin{array}{l}1.00 \\
1.00\end{array}$ & $\begin{array}{l}1.38(1.02-1.86) \\
0.74(0.46-1.19)\end{array}$ & $\begin{array}{l}1.24(0.91-1.68) \\
0.86(0.55-1.34)\end{array}$ & $\begin{array}{l}1.21(0.89-1.64) \\
0.83(0.53-1.29)\end{array}$ & $\begin{array}{l}0.37 \\
0.54\end{array}$ & $\begin{array}{l}1.03(0.94-1.14) \\
0.98(0.83-1.16)\end{array}$ \\
\hline $\begin{array}{l}\text { Linolenic acid } \\
\text { Median intake ( } \\
\text { men } \\
\text { Women } \\
\text { colon cancer ca } \\
\text { rectum cancer c } \\
\text { personyears } \\
\text { RR }(95 \% \mathrm{Cl})^{2}\end{array}$ & $\begin{array}{l}\text { /d) } \\
\text { ses } \\
\text { ases } \\
\text { colon } \\
\text { rectum }\end{array}$ & $\begin{array}{l}0.8 \\
0.6 \\
108 \\
44 \\
3642 \\
1.00 \\
1.00\end{array}$ & $\begin{array}{l}1.2 \\
0.9 \\
108 \\
40 \\
3684 \\
0.97(0.73-1.30) \\
0.89(0.57-1.38)\end{array}$ & $\begin{array}{l}1.5 \\
1.2 \\
124 \\
36 \\
3657 \\
1.15(0.87-1.52) \\
0.81(0.51-1.28)\end{array}$ & $\begin{array}{l}2.0 \\
1.6 \\
108 \\
40 \\
3750 \\
1.01(0.76-1.35) \\
0.90(0.58-1.41)\end{array}$ & $\begin{array}{l}0.65 \\
0.59\end{array}$ & $\begin{array}{l}0.99(0.90-1.09) \\
0.94(0.79-1.11)\end{array}$ \\
\hline $\operatorname{RR}(95 \% \mathrm{CI})^{3}$ & $\begin{array}{l}\text { colon } \\
\text { rectum }\end{array}$ & $\begin{array}{l}1.00 \\
1.00\end{array}$ & $\begin{array}{l}0.95(0.70-1.30) \\
0.91(0.57-1.47)\end{array}$ & $\begin{array}{l}1.10(0.82-1.47) \\
0.87(0.55-1.38)\end{array}$ & $\begin{array}{l}1.01(0.75-1.36) \\
0.91(0.58-1.44)\end{array}$ & $\begin{array}{l}0.70 \\
0.67\end{array}$ & $\begin{array}{l}0.98(0.89-1.09) \\
0.95(0.80-1.12)\end{array}$ \\
\hline
\end{tabular}




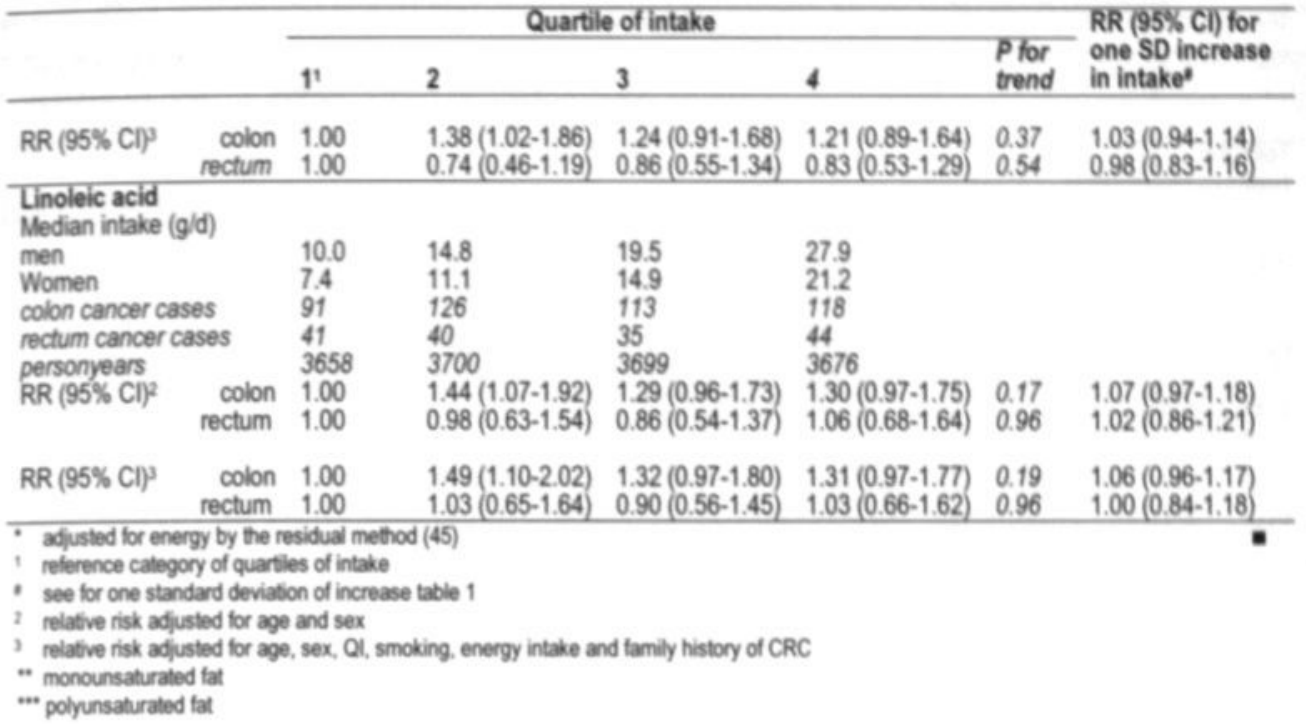

type K-ras tumours were observed for total fat, specific fatty acids and other (dietary) factors.

Associations between the intake of total fat, saturated fat, MUFA, PUFA, linolenic acid and linoleic acid with the risk of colon or rectal cancer are presented in table 2. Incidence rate ratios (RR) and $95 \% \mathrm{Cl}$ for colon and rectal cancer are adjusted for age and sex and for age, sex, smoking, QI, energy intake and family history of CRC. The age-sex adjusted RR and the multivariate RR were similar. Frequent consumption of total fat, saturated fat, MUFA, PUFA, linolenic acid and linoleic acid were all not associated with the risk of colon or rectal cancer (table 2).

Associations of total fat, saturated fat, MUFA, PUFA, linolenic and linoleic acid with wild type $K$-ras tumours and mutated $K$-ras tumours in the colon or rectum are presented in table 3. Results will first be discussed for wild type K-ras tumours. No clear associations were observed for high intakes of total fat, saturated fat, MUFA, PUFA, linolenic acid and linoleic acid and the risk of colon and rectal cancer with a wild type $K$-ras gene. With regard to the colon mutated $K$-ras tumours, positive associations were observed for high intakes of PUFA (RR for highest versus lowest quartile of intake $2.09,95 \% \mathrm{Cl} 1.25-3.49$, ptrend 0.002 ) and specifically linoleic acid (RR for highest versus lowest quartile of intake $2.19,95 \% \mathrm{Cl} 1.30$ 3.67, ptrend 0.002 ), but not linolenic acid. These positive associations were also observed for one SD of increase of intake (table 3). No significant associations were observed for rectal mutated $K$-ras tumours and for highest versus lowest intakes of total fat, saturated fat, MUFA and linolenic acid and colon and rectal cancer with mutated $K$-ras tumours.

Subgroup analyses were performed to evaluate the associations between total fat, saturated fat, MUFA, PUFA, linolenic acid and linoleic acid intakes and specific types of $K$-ras point mutations ( $\mathrm{G}>\mathrm{A}$ transitions and $\mathrm{G}>\mathrm{T}$ or $\mathrm{G}>\mathrm{C}$ transversions) in colon and rectal tumours (table 4). High intake of PUFA and specifically linoleic acid showed positive associations with colon tumours harbouring $G>A$ transitions (RR for highest versus lowest quartile of intake $1.95,95 \% \mathrm{Cl} 1.01-3.77$ and $\mathrm{RR} 1.80,95 \% \mathrm{Cl} 0.92-3.51$, respectively) or $\mathrm{G}>\mathrm{T}$ or $\mathrm{G}>\mathrm{C}$ transversions (RR 2.17, 95\% Cl 0.98-4.80 and RR 2.69, 95\% Cl 1.19-6.08, respectively). These positive associations were also observed for one SD of increase of intake (table 4). There were no associations found between PUFA and linoleic acid intake 
and rectal tumours with $\mathrm{G}>\mathrm{A}$ transitions or $\mathrm{G}>\mathrm{T}$ or $\mathrm{G}>\mathrm{C}$ transversions. In addition, no significant associations were observed between highest versus lowest quartile of intake of total fat, saturated fat, MUFA and linolenic acid and the risk of G>A transitions or $G>T$ or $\mathrm{G}>\mathrm{C}$ transversions in colon and rectal tumours.

\section{DISCUSSION}

In this study, no associations were observed between intakes of specific fats or fatty acids and overall colon and rectal cancer risk. However, associations were observed when taking into account the presence or absence of specific point mutations in the $K$-ras gene of colon and rectal cancer patients. No significant associations were observed for total fat, saturated fat, and MUFA intakes and the risk of colon and rectal tumours without or with a $K$ ras mutation. In contrast, positive associations were observed for high intake of PUFA, specifically linoleic acid but not linolenic acid, and the risk of colon tumours harbouring $K$-ras oncogene mutations. Subgroup analyses of specific point mutations in the $K$-ras gene revealed that these positive associations were observed for $G>A$ transitions and $G>T$ and $\mathrm{G}>\mathrm{C}$ transversions.

This cohort study on fat and specific fatty acids intake in relation to specific $K$-ras mutations in colon and rectal cancer is, to our knowledge, the only prospective study performed to date. One large case-control study with colon cancer patients (11), two casecontrol studies of limited size among colon (13), and colon and rectal cancer patients (12) and one cross-sectional case-case study with colorectal adenoma patients (14) have previously been conducted. The prospective design of the current study and high completeness of follow-up of cancer incidence and subcohort, make information and selection bias unlikely. In addition, as a result of the exclusion of the first 2.3 years of followup, the chance of information bias due to potential preclinical colorectal cancer is minimal. Finally, tumour tissue was available for $84 \%$ of the eligible cases (776 out of 929 ) and there were no significant differences in fat intake levels nor in clinicopathological characteristics of the tumour (Dukes' stage and differentiation grade) of these patients compared to the CRC patients with a known K-ras mutation status of their tumour (data not shown). Therefore, selection bias due to loss to follow-up is unlikely.

In general, the validation of the fat intake variables was satisfactory (see methods section and (27)). Although total fat intake and energy intake may have been underestimated as compared to the nine-day record method in the validation study (27) and, in addition, there is inevitably a certain degree of misclassification of fat intake variables, it is not expected that this is differential with respect to the $K$-ras mutation status of the tumour. Therefore, the associations observed in this study are probably attenuated. In other epidemiological studies similar inaccuracies occur in the measurement of fat intake since similar methods of intake assessment were employed $(11,12,14)$.

One of the hypotheses for the association between fat intake and CRC is that meat consumption instead of fat intake determines the increased risk. We also investigated meat consumption as a potential risk factor for $K$-ras mutations in colon and rectal cancer, and total fresh meat was not associated with risk. Therefore, we did not additionally adjusted for this potential confounder in these analyses.

In the current study, a high intake of total and saturated fats was not associated with overall colon or rectal cancer risk and with $K$-ras mutation status and these findings are supported by others $(11,13,14)$. Bautista et al (12) observed an inverse association between a high intake of total fat and colorectal tumours with a K-ras wild type gene (odds ratio for highest versus lowest tertile of intake $0.47,95 \% \mathrm{Cl} 0.22-0.99$ ). However, the results were 
Table 4 Adjusted $R^{1}$ for colon and rectal cancer patients with $G>A$ transitions or with $G>T$ or $G>C$ transversions in the $K$-ras oncogene according to the intake of intake total fat and specific fatty acids

\begin{tabular}{|c|c|c|c|c|c|c|c|}
\hline & \multicolumn{5}{|c|}{ Quartile of intake } & \multirow{2}{*}{$\begin{array}{l}\text { RR }(95 \% \mathrm{Cl}) \text { for } \\
\text { one SD increase } \\
\text { in intakes }\end{array}$} \\
\hline & & $1^{2}$ & 2 & 3 & 4 & $\begin{array}{l}\text { Pfor } \\
\text { trend }\end{array}$ & \\
\hline \multicolumn{8}{|c|}{$\begin{array}{l}\text { Total fat } \\
\text { Cases }(G>A) \rightarrow T \text { or } C)\end{array}$} \\
\hline & $\begin{array}{l}\text { colon } \\
\text { rectum }\end{array}$ & $\begin{array}{l}20 / 15 \\
127\end{array}$ & $\begin{array}{l}23 / 20 \\
6 / 7\end{array}$ & $\begin{array}{l}17 / 12 \\
6 / 7\end{array}$ & $\begin{array}{l}22 / 9 \\
9 / 11\end{array}$ & & \\
\hline $\operatorname{RR}_{\varpi_{A}}(95 \% \mathrm{Cl})$ & $\begin{array}{l}\text { colon } \\
\text { rectum }\end{array}$ & $\begin{array}{l}1.00 \\
1.00\end{array}$ & $\begin{array}{l}1.11(0.60-2.07) \\
0.45(0.17-1.22)\end{array}$ & $\begin{array}{l}0.78(0.40-1.52) \\
0.43(0.16-1.19)\end{array}$ & $\begin{array}{l}1.02(0.54-1.90) \\
0.74(0.31-1.79)\end{array}$ & $\begin{array}{l}0.79 \\
0.50\end{array}$ & $\begin{array}{l}1.09(0.82-1.44) \\
0.87(0.57-1.32)\end{array}$ \\
\hline RRot.c $(95 \% \mathrm{Cl})$ & $\begin{array}{c}\text { colon } \\
\text { rectum }\end{array}$ & $\begin{array}{l}1.00 \\
1.00\end{array}$ & $\begin{array}{l}1.26(0.64-2.48) \\
1.09(0.37-3.20)\end{array}$ & $\begin{array}{l}0.72(0.33-1.56) \\
1.07(0.37-3.11)\end{array}$ & $\begin{array}{l}0.57(0.25-1.30) \\
1.50(0.58-3.89)\end{array}$ & $\begin{array}{l}0.07 \\
0.42\end{array}$ & $\begin{array}{l}0.90(0.69-1.17) \\
1.17(0.84-1.63)\end{array}$ \\
\hline \multicolumn{8}{|c|}{$\begin{array}{l}\text { Saturated fat } \\
\text { Cases }(G>A) G>T \text { or } C)\end{array}$} \\
\hline $\operatorname{RR}_{\odot A}(95 \% \mathrm{Cl})$ & $\begin{array}{l}\text { colon } \\
\text { rectum } \\
\text { colon } \\
\text { rectum }\end{array}$ & $\begin{array}{l}23 / 14 \\
9 / 10 \\
1.00 \\
1.00\end{array}$ & $\begin{array}{l}16 / 17 \\
5 / 8 \\
0.69(0.36-1.34) \\
0.51(0.17-1.55)\end{array}$ & $\begin{array}{l}23 / 15 \\
13 / 3 \\
0.95(0.52-1.74) \\
1.31(0.55-3.10)\end{array}$ & $\begin{array}{l}20 / 10 \\
6 / 11 \\
0.76(0.41-1.42) \\
0.64(0.23-1.84)\end{array}$ & $\begin{array}{l}0.60 \\
0.88\end{array}$ & $\begin{array}{l}0.95(0.75-1.19) \\
1.01(0.70-1.45)\end{array}$ \\
\hline $\operatorname{RR}_{0, \mathrm{~T}, \mathrm{C}}(95 \% \mathrm{Cl})$ & $\begin{array}{c}\text { colon } \\
\text { rectum }\end{array}$ & $\begin{array}{l}1.00 \\
1.00\end{array}$ & $\begin{array}{l}1.19(0.57-2.47) \\
0.91(0.34-2.44)\end{array}$ & $\begin{array}{l}1.00(0.47-2.10) \\
0.33(0.08-1.25)\end{array}$ & $\begin{array}{l}0.63(0.28-1.43) \\
1.07(0.45-2.55)\end{array}$ & $\begin{array}{l}0.21 \\
0.84\end{array}$ & $\begin{array}{l}0.79(0.62-1.01) \\
1.15(0.80-1.64)\end{array}$ \\
\hline \multicolumn{8}{|c|}{$\begin{array}{l}\text { MUFA" } \\
\text { Cases }(G>A G \rightarrow T \text { or } C)\end{array}$} \\
\hline & $\begin{array}{l}\text { colon } \\
\text { rectum }\end{array}$ & $\begin{array}{l}19 / 17 \\
10 / 4\end{array}$ & $\begin{array}{l}21 / 18 \\
6 / 7\end{array}$ & $\begin{array}{l}25 / 13 \\
7 / 13\end{array}$ & $\begin{array}{l}17 / 8 \\
10 / 8\end{array}$ & & \\
\hline $\mathrm{RR}_{\infty} \mathrm{A}(95 \% \mathrm{Cl})$ & $\begin{array}{l}\text { colon } \\
\text { rectum }\end{array}$ & $\begin{array}{l}1.00 \\
1.00\end{array}$ & $\begin{array}{l}1.09(0.57-2.09) \\
0.53(0.19-1.46)\end{array}$ & $\begin{array}{l}1.34(0.70-2.56) \\
0.59(0.22-1.66)\end{array}$ & $\begin{array}{l}0.84(0.43-1.66) \\
0.96(0.40-2.33)\end{array}$ & $\begin{array}{l}0.78 \\
0.99\end{array}$ & $\begin{array}{l}1.05(0.80-1.39) \\
1.06(0.71-1.60)\end{array}$ \\
\hline RRertc (95\% Cl) & $\begin{array}{c}\text { colon } \\
\text { rectum }\end{array}$ & $\begin{array}{l}1.00 \\
1.00\end{array}$ & $\begin{array}{l}1.01(0.51-1.98) \\
2.00(0.57-7.07)\end{array}$ & $\begin{array}{l}0.72(0.34-1.51) \\
4.00(1.25-12.8)\end{array}$ & $\begin{array}{l}0.46(0.20-1.07) \\
1.93(0.57-6.56)\end{array}$ & $\begin{array}{l}0.04 \\
0.12\end{array}$ & $\begin{array}{l}0.78(0.60-1.02) \\
1.12(0.91-1.37)\end{array}$ \\
\hline \multicolumn{8}{|c|}{$\begin{array}{l}\text { PUFA". } \\
\text { Cases (G>A G G T or C) }\end{array}$} \\
\hline $\mathrm{RR}_{\odot \mathrm{A}}(95 \% \mathrm{Cl})$ & $\begin{array}{l}\text { colon } \\
\text { rectum } \\
\text { colon } \\
\text { rectum }\end{array}$ & $\begin{array}{l}14 / 9 \\
11 / 10 \\
1.00 \\
1.00\end{array}$ & $\begin{array}{l}18 / 13 \\
6 / 9 \\
1.44(0.71-2.94) \\
0.51(0.18-1.43)\end{array}$ & $\begin{array}{l}23 / 14 \\
11 / 4 \\
1.76(0.89-3.49) \\
0.86(0.35-2.11)\end{array}$ & $\begin{array}{l}27 / 20 \\
5 / 9 \\
1.95(1.01-3.77) \\
0.42(0.14-1.20)\end{array}$ & $\begin{array}{l}0.04 \\
0.21\end{array}$ & $\begin{array}{l}1.18(0.97-1.42) \\
0.80(0.57-1.12)\end{array}$ \\
\hline $\operatorname{RR}$ RT.C $(95 \% \mathrm{Cl})$ & $\begin{array}{c}\text { colon } \\
\text { rectum }\end{array}$ & $\begin{array}{l}1.00 \\
1.00\end{array}$ & $\begin{array}{l}1.51(0.64-3.60) \\
1.10(0.44-2.74)\end{array}$ & $\begin{array}{l}1.57(0.67-3.70) \\
0.45(0.14-1.46)\end{array}$ & $\begin{array}{l}2.17(0.98-4.80) \\
0.94(0.38-2.30)\end{array}$ & $\begin{array}{l}0.06 \\
0.59\end{array}$ & $\begin{array}{l}1.24(0.98-1.57) \\
1.02(0.72-1.45)\end{array}$ \\
\hline \multicolumn{8}{|c|}{$\begin{array}{l}\text { Linolenic acid } \\
\text { Cases }(G>A \wedge G>T \text { or } C)\end{array}$} \\
\hline $\operatorname{RR}_{\odot \wedge}(95 \% \mathrm{Cl})$ & $\begin{array}{l}\text { colon } \\
\text { rectum } \\
\text { colon } \\
\text { rectum }\end{array}$ & $\begin{array}{l}24 / 14 \\
6 / 6 \\
1.00 \\
1.00\end{array}$ & $\begin{array}{l}13 / 18 \\
8 / 9 \\
0.54(0.26-1.11) \\
1.04(0.33-3.28)\end{array}$ & $\begin{array}{l}24 / 14 \\
9 / 11 \\
1.02(0.57-1.85) \\
1.39(0.47-4.04)\end{array}$ & $\begin{array}{l}21 / 10 \\
11 / 6 \\
0.91(0.49-1.70) \\
1.75(0.62-4.95)\end{array}$ & $\begin{array}{l}0.79 \\
0.22\end{array}$ & $\begin{array}{l}1.04(0.83-1.29) \\
1.21(0.92-1.59)\end{array}$ \\
\hline $\operatorname{RR}_{\text {GT.C }}(95 \% \mathrm{Cl})$ & $\begin{array}{c}\text { colon } \\
\text { rectum }\end{array}$ & $\begin{array}{l}1.00 \\
1.00\end{array}$ & $\begin{array}{l}1.26(0.57-2.80) \\
1.91(0.64-5.66)\end{array}$ & $\begin{array}{l}1.00(0.47-2.14) \\
2.21(0.81-6.03)\end{array}$ & $\begin{array}{l}0.75(0.32-1.72) \\
1.09(0.35-3.38)\end{array}$ & $\begin{array}{l}0.38 \\
0.75 \\
\end{array}$ & $\begin{array}{l}0.95(0.73-1.25) \\
0.92(0.71-1.20)\end{array}$ \\
\hline \multicolumn{8}{|c|}{$\begin{array}{l}\text { Linoleic acid } \\
\text { Cases }(G>A \vee G>T \text { or } C)\end{array}$} \\
\hline & $\begin{array}{l}\text { colon } \\
\text { rectum }\end{array}$ & $\begin{array}{l}14 / 8 \\
11 / 10\end{array}$ & $\begin{array}{l}19 / 14 \\
6 / 7\end{array}$ & $\begin{array}{l}24 / 12 \\
10 / 6\end{array}$ & $\begin{array}{l}25 / 22 \\
7 / 9\end{array}$ & & \\
\hline $\operatorname{RR}_{\odot A}(95 \% \mathrm{Cl})$ & $\begin{array}{l}\text { colon } \\
\text { rectum }\end{array}$ & $\begin{array}{l}1.00 \\
1.00\end{array}$ & $\begin{array}{l}1.51(0.75-3.07) \\
0.56(0.19-1.60)\end{array}$ & $\begin{array}{l}1.85(0.93-3.66) \\
0.89(0.35-2.26)\end{array}$ & $\begin{array}{l}1.80(0.92-3.51) \\
0.65(0.24-1.74)\end{array}$ & $\begin{array}{l}0.06 \\
0.59\end{array}$ & $\begin{array}{l}1.19(0.98-1.44) \\
0.81(0.57-1.15)\end{array}$ \\
\hline $\operatorname{RR}_{\mathrm{QT}, \mathrm{C}}(95 \% \mathrm{Cl})$ & $\begin{array}{c}\text { colon } \\
\text { rectum }\end{array}$ & $\begin{array}{l}1.00 \\
1.00\end{array}$ & $\begin{array}{l}1.83(0.76-4.40) \\
0.83(0.31-2.27)\end{array}$ & $\begin{array}{l}1.52(0.61-3.77) \\
0.70(0.25-1.94)\end{array}$ & $\begin{array}{l}2.69(1.19-6.08) \\
0.94(0.38-2.31)\end{array}$ & $\begin{array}{l}0.03 \\
0.83\end{array}$ & $\begin{array}{l}1.27(1.00-1.61) \\
1.06(0.74-1.53)\end{array}$ \\
\hline Multivariate adjusted & $\begin{array}{l}\text { RR for age, } \\
\text { idual method } \\
\text { quartiles of }\end{array}$ & $\begin{array}{l}\text { sex, Ql, s } \\
\text { d (45) } \\
\text { fintake }\end{array}$ & moking, energy intake & and family history of C & CRC and their $95 \%$ co & onfidence i & ntervals and adjusted \\
\hline
\end{tabular}


based on only 108 CRC cases in a population-based case-control setting, and therefore estimates of associations must be interpreted with caution.

Animal studies indicated an inverse association of high MUFA intake, derived mainly from oleic acid with CRC risk $(32,33)$. However, in epidemiological studies, no clear associations were observed with CRC risk (34-36). Regarding the $K$-ras mutation status, no associations were observed for high intake of MUFA and the risk of colon and rectal cancer in the current study. This is in line with Slattery's observation (11). However, Bautista et al (12) observed that a high intake of MUFA was inversely associated with the risk of having a wild type $K$-ras gene. This study was conducted in Spain where the main source of oleic acid is olive oil. This is not the case for the current cohort and could be an explanation for the different findings. The association was not reported in the other studies $(13,14)$.

To our best knowledge, this is the first study reporting on specific polyunsaturated fatty acids in relation to $K$-ras mutation status. Overall PUFA intake was studied by Slattery et al (11) and Bautista et al (12) and no associations were observed with $K$-ras mutation status.

In the current study, no clear associations were observed between the high intake of linolenic acid as the main source of $\omega-3$ PUFA, and the risk of colon or rectal cancer with or without specific point mutations in the $K$-ras gene. Epidemiological, clinical, and experimental data indicate a protective effect of fish oil-derived $\omega-3$ PUFA on overall colon cancer (35,37-44). Collett et al (37) demonstrated that the major $\omega-3$ PUFA constituent of fish oil, docosahexaenoic acid (DHA) reduces the Ras protein localization to the plasma membrane without affecting posttranslational lipidation and lowers the GTP-binding of the Ras protein in mouse colonocytes treated with azoxymethane (colon carcinogen). These findings were corroborated by in vivo studies (45). Another hypothesis is that the tumourpromoting activity of $\omega-6$ PUFA was abrogated by competitive inhibition of $\omega-3$ PUFA from the metabolism of arachidonic acid and therefore reducing malondialdehyde (MDA) levels and subsequently pyrimidopurinone-deoxyguanosine $\left(M_{1} G\right)$ adducts $M_{1} G>T$ and $M_{1} G>C$ transversions (38). Summarized, w-3 PUFA may exert their effect through inhibition of the Ras protein activity and not by generating functional aberrations in the exon 1 fragment of the $K$-ras oncogene. This could explain the lack of association between linolenic acid and $K$ ras mutation status of colon or rectal tumours in this study.

In the current study, no significant association was observed for linoleic acid, as the main source of $\omega-6$ PUFA intake, and the overall risk of colon or rectal cancer. This is in line with most epidemiological evidence up to date (46). However, a positive effect was found between high intake of linoleic acid and colon tumours harbouring $K$-ras gene mutations. Subgroup analyses of specific point mutations in the $K$-ras gene revealed that colon tumours harbouring $\mathrm{G}>\mathrm{A}$ transitions or $\mathrm{G}>\mathrm{T}$ or $\mathrm{G}>\mathrm{C}$ transversions are positively associated with high linoleic acid intake. These associations are in line with the biological evidence $(16,18)$ and are possibly the result of an increased formation of $\mathrm{G}$-adducts resulting in $\mathrm{G}>\mathrm{A}$ transitions or $\mathrm{G}>\mathrm{T}$ or $\mathrm{G}>\mathrm{C}$ transversions. Increased intake of $\omega-6$ PUFA enhances tumorigenesis in experimental animals and in vitro systems by several mechanisms (47). The conjugated double bonds in poly-unsaturated fatty acids are highly sensitive to lipid peroxidation, and may generate fatty acid hydroperoxides. These hydroperoxides will be reduced by glutathione peroxidase to non-reactive fatty acid alcohols or may react with metal ions to yield alkoxyl radicals. The fatty acid alcohols do not lead to DNA damage and will not be discussed further. However, alkoxyl radicals are reduced to aldehydes, with 2,3-epoxy-4hydroxynonanal (4-HNE) and MDA as the most prominent forms. The bifunctional alkylating agent 4-HNE can react with DNA to yield etheno and other base adducts which are thought to promote the carcinogenic process. Etheno-dG induces mainly transitions to $A$ and transversions to $T$ in bacteria $(16,33,48,49)$ and etheno-dC induces transitions to $T$ in the kidneys of monkeys (50). MDA is a major genotoxic carbonyl compound, which is also a by-product of the arachidonic acid metabolism in the synthesis of prostaglandines. MDA is 
mutagenic in bacterial and mammalian cells, and carcinogenic in rats (18). MDA reacts with DNA to form adducts, predominantly with deoxyguanosine to generate $M_{1} G$ (15). The most common mutations in progeny molecules are $\mathrm{G}>\mathrm{T}$ transversions and $\mathrm{G}>\mathrm{A}$ transitions, with a minor contribution by $G>C$ transversions $(16,18,19)$. In the current study, the associations with $G>A$ transitions, $G>T$ and $G>C$ transversions in the $K$-ras oncogene were only observed for colon cancer patients and not for rectal cancer patients. The reason for this apparent difference in the aetiology remains unclear. In addition, the observed significant association found for colon cancer could be a result of a type I error due to the numerous associations analysed in this study. Although the studied associations were mainly hypotheses-driven, caution is warranted in interpreting these results and further investigations are needed.

Our results suggest that PUFA, and in particular linoleic acid, is an important dietary risk factor for colon tumours with $K$-ras mutations possibly by generating $G>A$ transitions or $G>T$ or $\mathrm{G}>\mathrm{C}$ transversions in the exon 1 fragment of the $K$-ras oncogene. This implies that, for some dietary exposures like polyunsaturated fat intake, it is meaningful to account for somatic mutations in the $K$-ras oncogene in the aetiology of colon and rectal cancer.

\section{REFERENCES}

1. Potter JD. (1996) Nutrition and colorectal cancer. Cancer Causes Control, 7, 127-46.

2. Giovannucci E and Willett WC. (1994) Dietary factors and risk of colon cancer. Ann Med, 26, 443-52.

3. Hill MJ, Morson BC and Bussey HJ. (1978) Aetiology of adenoma--carcinoma sequence in large bowel. Lancet, 1, 245-7.

4. Vogelstein B, Fearon ER, Hamilton SR, Kern SE, Preisinger AC, Leppert M, Nakamura Y, White R, Smits AM and Bos JL. (1988) Genetic alterations during colorectal-tumor development. N Engl J Med, 319, 525-32.

5. Fearon ER and Vogelstein B. (1990) A genetic model for colorectal tumorigenesis. Cell, 61, 759-67.

6. Bos JL, Fearon ER, Hamilton SR, Verlaan-de Vries M, van Boom JH, van der Eb AJ and Vogelstein B. (1987) Prevalence of ras gene mutations in human colorectal cancers. Nature, 327, 293-7.

7. Breivik J, Meling GI, Spurkland A, Rognum TO and Gaudernack G. (1994) K-ras mutation in colorectal cancer: relations to patient age, sex and tumour location. $\mathrm{Br} J$ Cancer, 69, 367-71.

8. Brink M, De Goeij AF, Weijenberg MP, Roemen GM, Lentjes MH, Pachen MM, Smits KM, De Bruïne AP, Goldbohm RA and van den Brandt PA. (2003) K-ras oncogene mutations in sporadic colorectal cancer in The Netherlands Cohort Study. Carcinogenesis, 24, 703-710.

9. Martinez-Garza SG, Nunez-Salazar A, Calderon-Garciduenas AL, Bosques-Padilla FJ, Niderhauser-Garcia A and Barrera-Saldana HA. (1999) Frequency and clinicopathology associations of K-ras mutations in colorectal cancer in a northeast Mexican population. Dig Dis, 17, 225-9.

10. Urosevic N, Krtolica K, Skaro-Milic A, Knezevic-Usaj S and Dujic A. (1993) Prevalence of G-to-T transversions among K-ras oncogene mutations in human colorectal tumors in Yugoslavia. Int J Cancer, 54, 249-54.

11. Slattery ML, Curtin K, Anderson K, Ma KN, Edwards S, Leppert M, Potter J, Schaffer D and Samowitz WS. (2000) Associations between dietary intake and Ki-ras mutations in colon tumors: a population-based study. Cancer Res, 60, 6935-41. 
12. Bautista D, Obrador A, Moreno V, Cabeza E, Canet R, Benito E, Bosch X and Costa J. (1997) Ki-ras mutation modifies the protective effect of dietary monounsaturated fat and calcium on sporadic colorectal cancer. Cancer Epidemiol Biomarkers Prev, 6, 57-61.

13. Kampman E, Voskuil DW, van Kraats AA, Balder HF, van Muijen GN, Goldbohm RA and van't Veer P. (2000) Animal products and K-ras codon 12 and 13 mutations in colon carcinomas. Carcinogenesis, 21, 307-9.

14. Martinez ME, Maltzman T, Marshall JR, Einspahr J, Reid ME, Sampliner R, Ahnen DJ, Hamilton SR and Alberts DS. (1999) Risk factors for Ki-ras protooncogene mutation in sporadic colorectal adenomas. Cancer Res, 59, 5181-5.

15. Leuratti C, Watson MA, Deag EJ, Welch A, Singh R, Gottschalg E, Marnett LJ, Atkin W, Day NE, Shuker DE and Bingham SA. (2002) Detection of malondialdehyde DNA adducts in human colorectal mucosa: relationship with diet and the presence of adenomas. Cancer Epidemiol Biomarkers Prev, 11, 267-73.

16. Marnett LJ. (2000) Oxyradicals and DNA damage. Carcinogenesis, 21, 361-70.

17. Sharma RA, Ireson CR, Verschoyle RD, Hill KA, Williams ML, Leuratti C, Manson MM, Marnett LJ, Steward WP and Gescher A. (2001) Effects of dietary curcumin on glutathione S-transferase and malondialdehyde-DNA adducts in rat liver and colon mucosa: relationship with drug levels. Clin Cancer Res, 7, 1452-8.

18. Burcham PC. (1999) Internal hazards: baseline DNA damage by endogenous products of normal metabolism. Mutat Res, 443, 11-36.

19. Fink SP, Reddy GR and Marnett LJ. (1997) Mutagenicity in Escherichia coli of the major DNA adduct derived from the endogenous mutagen malondialdehyde. Proc Natl Acad Sci U S A, 94, 8652-7.

20. van den Brandt PA, Goldbohm RA, van 't Veer P, Volovics A, Hermus RJ and Sturmans F. (1990) A large-scale prospective cohort study on diet and cancer in The Netherlands. $J$ Clin Epidemiol, 43, 285-95.

21. van den Brandt PA, Schouten LJ, Goldbohm RA, Dorant E and Hunen PM. (1990) Development of a record linkage protocol for use in the Dutch Cancer Registry for Epidemiological Research. Int J Epidemiol, 19, 553-8.

22. Schouten LJ, Hoppener P, van den Brandt PA, Knottnerus JA and Jager JJ. (1993) Completeness of cancer registration in Limburg. The Netherlands. Int J Epidemiol, 22, 369-76.

23. Schouten LJ, Straatman H, Kiemeney LA, Gimbrere CH and Verbeek AL. (1994) The capture-recapture method for estimation of cancer registry completeness: a useful tool? Int J Epidemiol, 23, 1111-6.

24. van der Sanden GA, Coebergh JW, Schouten LJ, Visser O and van Leeuwen FE. (1995) Cancer incidence in The Netherlands in 1989 and 1990: first results of the nationwide Netherlands cancer registry. Coordinating Committee for Regional Cancer Registries. Eur J Cancer, 31A, 1822-9.

25. Goldbohm RA, van den Brandt PA and Dorant E. (1994) Estimation of the coverage of municipalities by cancer registries and PALGA using hospital discharge data. Tijdsch Soc Gezondheidsz, 72, 80-84.

26. Nevo table (1986) Dutch food composition table 1986-1987, The Hague, The Netherlands: Voorlichtingsbureau voor de voeding.

27. Goldbohm RA, van den Brandt PA, Brants HA, van't Veer P, Al M, Sturmans F and Hermus RJ (1994) Validation of a dietary questionnaire used in a large-scale prospective cohort study on diet and cancer. Eur J Clin Nutr, 48, 253-65.

28. Van Poppel G, Van Erp-Baart M-A and Leth T. (1998) Trans fatty acids in foods in Europe: the TRANSFAIR study. Journal of Food Composition Anal, 11, 112-136.

29. Willet W. (1990) Nutritional epidemiology. New York: Oxford University Press. 
30. Barlow WE, Ichikawa L, Rosner D and Izumi S. (1999) Analysis of case-cohort designs. $J$ Clin Epidemiol, 52, 1165-72.

31. Schoenfeld D. (1982) Partial residuals for the proportional hazards regression model. Biometrika, 69, 239-241.

32. Takeshita M, Ueda H, Shirabe K, Higuchi Y and Yoshida S. (1997) Lack of promotion of colon carcinogenesis by high-oleic safflower oil. Cancer, 79, 1487-93.

33. Bartsch H, Nair J and Owen RW. (1999) Dietary polyunsaturated fatty acids and cancers of the breast and colorectum: emerging evidence for their role as risk modifiers. Carcinogenesis, 20, 2209-18.

34. Chyou PH, Nomura AM and Stemmermann GN. (1996) A prospective study of colon and rectal cancer among Hawaii Japanese men. Ann Epidemiol, 6, 276-82.

35. Giovannucci E and Goldin B. (1997) The role of fat, fatty acids, and total energy intake in the etiology of human colon cancer. Am J Clin Nutr, 66, 1564S-1571S.

36. Ghadirian P, Lacroix A, Maisonneuve P, Perret C, Potvin C, Gravel D, Bernard D and Boyle P. (1997) Nutritional factors and colon carcinoma: a case-control study involving French Canadians in Montreal, Quebec, Canada. Cancer, 80, 858-64.

37. Collett ED, Davidson LA, Fan YY, Lupton JR and Chapkin RS. (2001) n-6 and n-3 polyunsaturated fatty acids differentially modulate oncogenic Ras activation in colonocytes. Am J Physiol Cell Physiol, 280, C1066-75.

38. Woutersen RA, Appel MJ, van Garderen-Hoetmer A and Wijnands MV. (1999) Dietary fat and carcinogenesis. Mutat Res, 443, 111-27.

39. Willett WC, Stampfer MJ, Colditz GA, Rosner BA and Speizer FE. (1990) Relation of meat, fat, and fiber intake to the risk of colon cancer in a prospective study among women [see comments]. N Engl J Med, 323, 1664-72.

40. Anti M, Armelao F, Marra G, Percesepe A, Bartoli GM, Palozza P. Parrella P, Canetta C, Gentiloni N, De Vitis I et al. (1994) Effects of different doses of fish oil on rectal cell proliferation in patients with sporadic colonic adenomas. Gastroenterology, 107, 170918.

41. Chang WL, Chapkin RS and Lupton JR. (1998) Fish oil blocks azoxymethane-induced rat colon tumorigenesis by increasing cell differentiation and apoptosis rather than decreasing cell proliferation. J Nutr, 128, 491-7.

42. Lee DY, Lupton JR, Aukema HM and Chapkin RS. (1993) Dietary fat and fiber alter rat colonic mucosal lipid mediators and cell proliferation. J Nutr, 123, 1808-17.

43. Minoura T, Takata T, Sakaguchi M, Takada H, Yamamura M, Hioki K and Yamamoto M. (1988) Effect of dietary eicosapentaenoic acid on azoxymethane-induced colon carcinogenesis in rats. Cancer Res, 48, 4790-4.

44. Davidson LA, Lupton JR, Jiang YH and Chapkin RS. (1999) Carcinogen and dietary lipid regulate ras expression and localization in rat colon without affecting farnesylation kinetics. Carcinogenesis, 20, 785-91.

45. Hong MY, Lupton JR, Morris JS, Wang N, Carroll RJ, Davidson LA, Elder RH and Chapkin RS. (2000) Dietary fish oil reduces O6-methylguanine DNA adduct levels in rat colon in part by increasing apoptosis during tumor initiation. Cancer Epidemiol Biomarkers Prev, 9, 819-26.

46. Zock PL and Katan MB. (1998) Linoleic acid intake and cancer risk: a review and metaanalysis. Am J Clin Nutr, 68, 142-53.

47. Fay MP, Freedman LS, Clifford CK and Midthune DN. (1997) Effect of different types and amounts of fat on the development of mammary tumors in rodents: a review. Cancer Res, 57, 3979-88.

48. Benamira M, Singh U and Marnett LJ. (1992) Site-specific frameshift mutagenesis by a propanodeoxyguanosine adduct positioned in the (CpG)4 hot-spot of Salmonella typhimurium hisD3052 carried on an M13 vector. J Biol Chem, 267, 22392-400. 
49. Moriya M, Zhang W, Johnson F and Grollman AP. (1994) Mutagenic potency of exocyclic DNA adducts: marked differences between Escherichia coli and simian kidney cells. Proc Natl Acad Sci U S A, 91, 11899-903.

50. Pandya GA and Moriya M. (1996) 1,N6-ethenodeoxyadenosine, a DNA adduct highly mutagenic in mammalian cells. Biochemistry, 35, 11487-92. 


\section{Dietary folate intake and $K$-ras mutations in sporadic colon and rectal cancer in The Netherlands Cohort Study}




\title{
Dietary folate intake and $K$-ras mutations in sporadic colon and rectal cancer in The Netherlands Cohort Study
}

\author{
Mirian Brink ${ }^{1}$ \\ Matty P Weijenberg ${ }^{1}$ \\ Anton FPM de Goeij ${ }^{2}$ \\ Guido MJM Roemen ${ }^{3}$ \\ Marjolein HFM Lentjes ${ }^{3}$ \\ Adriaan $\mathrm{P}$ de Bruïne ${ }^{2}$ \\ Manon van Engeland ${ }^{2}$ \\ R Alexandra Goldbohm ${ }^{4}$ \\ Piet A van den Brandt ${ }^{1}$
}

'Nutrition and Toxicology Research Institute Maastricht (NUTRIM), Dept. of Epidemiology, Maastricht University, The Netherlands

${ }^{2}$ Research Institute Growth and Development (GROW), Dept. of Pathology, Maastricht University, The Netherlands

${ }^{3}$ NUTRIM, Dept. of Pathology, Maastricht University, The Netherlands

${ }^{4}$ TNO Nutrition and Food Research, Zeist, The Netherlands 


\section{ABSTRACT}

The association between dietary folate and specific $K$-ras mutations in colon and rectal cancer was investigated in The Netherlands Cohort Study on diet and cancer.

After 7.3 years of follow-up, 448 colon and 160 rectal cancer patients and 3048 subcohort members (55-69 years at baseline) were available for data-analyses. Mutation analysis of the $K$-ras gene was performed on all archival adenocarcinoma specimens. Casecohort analyses were used to compute adjusted incidence rate ratios (RR) and $95 \%$ confidence intervals $(\mathrm{Cl})$ for colon and rectal cancer overall and for $\mathrm{K}$-ras mutation status subgroups according to $100 \mu \mathrm{g} / \mathrm{d}$ increased intake in dietary folate.

Dietary folate intake was not significantly associated with colon cancer risk for men or women, either overall or with $K$-ras mutation status. For rectal cancer, high folate intake was inversely associated with the disease risk in men and was most pronounced for $K$-ras mutated tumours, whereas an increased association was observed for women. Regarding the $K$-ras mutation status in women, an increased association was observed for both wild type and mutated $K$-ras tumours. Specifically, folate intake was positively associated with $\mathrm{G}>\mathrm{T}$ and $\mathrm{G}>\mathrm{C}$ transversions in rectal tumours (RR 2.69, 95\% $\mathrm{Cl} 1.43-5.09$ ), but inversely associated with $\mathrm{G}>\mathrm{A}$ transitions (RR $0.08,95 \% \mathrm{Cl} 0.01-0.53$ ).

Our data suggest that the effect of folate intake on rectal cancer risk is different for men and women, and depends on the $K$-ras mutation status of this cancer type. 


\section{INTRODUCTION}

To date, results from epidemiological studies (1-4) generally show an inverse association between dietary folate and the risk of colorectal cancer (CRC). However, associations may be different for men versus women and for colon versus rectum $(4,5)$. In addition, the results from most animal studies support the epidemiological data, but results were not always consistent $(1,2)$.

Folate plays an important role in one-carbon metabolism, a series of interrelated biochemical reactions involved in DNA synthesis and methylation of DNA, RNA, and proteins $(6)$ in animals and humans. Two pathways have been described linking a low folate status to colon and rectal carcinogenesis $(6,7)$. First, a deficient intracellular form of folate, 5 , 10-methylenetetra-hydrofolate (5, 10-methyleneTHF) leads to a decreased availability of methyl groups for uracil which may result in less available thymine. Eventually, the increased uracil incorporation in DNA may lead to DNA strand breaks and chromosome instability. Secondly, sub-optimal folate status may result in global DNA hypomethylation and regional hypermethylation in gene promoters which interferes with gene expression and can impair DNA repair $(8,9)$. DNA strand breaks, global DNA hypomethylation and regional promoter hypermethylation are common events in colon cancer.

The association between folate and CRC was evaluated earlier in The Netherlands Cohort Study on diet and cancer (NLCS), based on 7.3 years of follow-up $(3,10)$. In this study (3), the association between folate intake and colon cancer tended to be inverse for men and women after the exclusion of the first year of follow-up, but did not reach statistical significance. For rectal cancer, folate was inversely associated with the disease risk in men, although borderline significant, but not in women. Evaluating these findings, it would be interesting to study the association between dietary folate and CRC when specific mutations in genes involved in colorectal carcinogenesis are taken into account.

The oncogenic activation of $K$-ras by mutations is a genetic alteration that occurs in adenomas $(10 \%)$ as well as in carcinomas $(40 \%)$ in colon and rectal cancer. Activating mutations are mainly found in codons 12 and 13 (11-14). The most frequently observed types of point mutations are $G>A$ transitions, and $G>T$ and $G>C$ transversions (14-16). Possibly, the $G>A$ transitions frequently observed in the $K$-ras gene are a result of impaired promoter methylation of the DNA-repair gene $0^{6}$-methylguanine DNA methyltransferase (MGMT) (9) which could, in part, be due to a low folate status (10).

To date, only three epidemiological studies report on the association between folate intake and K-ras mutation status in colorectal adenomas (7) and in colon(rectal) tumours $(17,18)$ with varying results. However, it is difficult to compare the results from different studies due to differences in case groups and reference groups. In the current study, the association between dietary folate intake and the risk of specific point mutations in the $K$-ras oncogene in patients with colon and rectal cancer were studied for men and women within the framework of the NLCS.

\section{MATERIALS AND METHODS}

\section{Study Population}

The participants in this study are incident colon and rectal cancer cases and subcohort members from the NLCS, which has been described in detail elsewhere (19). Briefly, the study was initiated in 1986 and includes 58,279 men and 62,573 women, aged 55-69 years old at baseline, who originated from 204 Dutch municipalities with computerized population registries. A self-administered questionnaire on diet and other risk factors for cancer was completed at baseline. The entire cohort is being monitored for cancer occurrence by annual 
Table 1 Nutrient intake (mean \pm SD) and other characteristics among colon cancer cases and subcohort members

\begin{tabular}{|c|c|c|c|c|}
\hline & \multicolumn{4}{|c|}{ Men } \\
\hline & \multirow[t]{2}{*}{ Subcohort } & \multicolumn{3}{|c|}{ Colon cancer } \\
\hline & & Wild type K-ras & K-ras mutation & $p$-value" \\
\hline $\mathrm{N}$ & 1475 & 153 & 89 & \\
\hline Age (y) & $61.3 \pm 4.2$ & $62.5 \pm 4.2$ & $63.7 \pm 4.2$ & 0.04 \\
\hline Folate ( $\mu g /$ day) & & $225.4 \pm 62.9$ & $225.1 \pm 83.6$ & 0.97 \\
\hline \multicolumn{5}{|l|}{ Other dietary factors } \\
\hline Alcohol (g/day) & $14.5 \pm 16.4$ & $15.7 \pm 16.4$ & $15.6 \pm 15.9$ & 0.95 \\
\hline Fiber (g/day)" & $28.7 \pm 8.8$ & $28.8 \pm 7.2$ & $29.7 \pm 8.9$ & 0.40 \\
\hline Energy (kcaliday) & $2165.6 \pm 512.1$ & $2157.1 \pm 452.6$ & $2069.4 \pm 438.6$ & 0.14 \\
\hline Fresh meat (g/day) & $105.9 \pm 43.3$ & $101.5 \pm 35.9$ & $103.6 \pm 36.9$ & 0.66 \\
\hline Vitamin B6 (mg/day) & $1.5 \pm 0.4$ & $1.6 \pm 0.3$ & $1.6 \pm 0.4$ & 0.90 \\
\hline Vitamin C (mg/day)" & $98.1 \pm 41.5$ & $100.9 \pm 41.5$ & $108.5 \pm 42.9$ & 0.18 \\
\hline Iron (mg/day) & $13.2 \pm 3.2$ & $13.5 \pm 2.9$ & $13.7 \pm 3.3$ & 0.68 \\
\hline Methionine (g/day) & $1.7 \pm 0.4$ & $1.7 \pm 0.4$ & $1.7 \pm 0.4$ & 0.16 \\
\hline \multicolumn{5}{|l|}{ Other characteristics } \\
\hline Ql $\left(\mathrm{kg} / \mathrm{m}^{2}\right)$ & $25.0 \pm 2.6$ & $25.3 \pm 2.6$ & $25.9 \pm 3.1$ & 0.11 \\
\hline Family history (\% Yes) & 5.7 & 13.7 & 11.2 & 0.58 \\
\hline \multicolumn{5}{|l|}{ Smoker $(\%)$} \\
\hline Never & 13.4 & 11.8 & 11.2 & \\
\hline Ex smoker & 51.3 & 62.1 & 67.4 & \\
\hline Current smoker & 35.3 & 26.1 & 21.3 & 0.67 \\
\hline \multicolumn{5}{|l|}{ Physical activity (\%) } \\
\hline$<30$ minutes/day & 15.0 & 10.6 & 11.4 & \\
\hline 30-60 minutes/day & 29.7 & 31.8 & 27.3 & \\
\hline 60-90 minutes/day & 34.8 & 32.5 & 38.6 & \\
\hline$>90$ minutes/day & 20.4 & 25.2 & 22.7 & 0.76 \\
\hline
\end{tabular}

record linkage to The Netherlands Cancer Registry (NCR, nine cancer registries in The Netherlands) and to PALGA, a nationwide network and registry of histo- and cytopathology (www.palga.nl) (20). In the municipalities included in the NLCS, the NCR and PALGA, together, have nearly $100 \%$ coverage since the start of the study $(21-23)$. PALGA also provides necessary information on the identification of the pathology laboratory location of the storage of paraffin-embedded blocks of the eligible CRC patients. Accumulation of persontime in the cohort has been estimated through biennial vital status follow-up of a subcohort of 3,500 men and women who were randomly selected after baseline exposure measurement. Cases with prevalent cancer other than non-melanoma skin cancer were excluded from the subcohort, which left 3,346 men and women for analysis.

The first 2.3 years of follow-up were excluded due to incomplete coverage of PALGA alone in some of the municipalities included in the NLCS. Within this period, 83 subcohort members were either deceased or diagnosed with cancer other than non-melanoma skin cancer, leaving 3,263 men and women for analysis. From 1989 till 1994, 929 incident cases with histologically confirmed CRC were observed of whom 819 could also be linked to a PALGA report of the lesion. The PALGA database was used to identify and locate tumour tissue in Dutch pathology laboratories. CRC was classified according to site as follows: colon i.e. cecum through sigmoid colon (ICD-O-1 codes: 153.0, 153.1, 153.2, 153.3, 153.4, $153.5,153.6,153.7,153.8,153.9)$, rectosigmoid (ICD-O-1 code 154.0) and rectum (ICD-O-1 code 154.1). Information about age at baseline, sex and family history of CRC (at baseline) was retrieved from the NLCS database. 
Table 1 Continued

\begin{tabular}{|c|c|c|c|}
\hline \multicolumn{4}{|c|}{ Women } \\
\hline \multirow{2}{*}{ Subcohort } & \multicolumn{3}{|c|}{ Colon cancer } \\
\hline & Wild type K-ras & K-ras mutation & p-value \\
\hline $\begin{array}{l}1573 \\
61.4 \pm 4.3 \\
199.8 \pm 64.7\end{array}$ & $\begin{array}{l}144 \\
62.8 \pm 4.1 \\
189.4 \pm 67.3\end{array}$ & $\begin{array}{l}62 \\
63.9 \pm 3.6 \\
192.9 \pm 61.6\end{array}$ & $\begin{array}{l}0.06 \\
0.72\end{array}$ \\
\hline $\begin{array}{l}5.7 \pm 9.4 \\
25.5 \pm 7.2 \\
1691.4 \pm 408.5 \\
93.8 \pm 40.4 \\
1.3 \pm 0.3 \\
108.2 \pm 43.8 \\
11.7 \pm 2.7 \\
1.5 \pm 0.4\end{array}$ & $\begin{array}{l}6.0 \pm 12.4 \\
24.4 \pm 7.4 \\
1660.9 \pm 400.7 \\
95.2 \pm 38.0 \\
1.3 \pm 0.3 \\
102.0 \pm 47.1 \\
11.4 \pm 2.4 \\
1.5 \pm 0.3\end{array}$ & $\begin{array}{l}3.9 \pm 7.0 \\
24.9 \pm 7.9 \\
1663.5 \pm 416.7 \\
93.1 \pm 41.6 \\
1.3 \pm 0.3 \\
105.7 \pm 47.4 \\
11.2 \pm 2.9 \\
1.5 \pm 0.4\end{array}$ & $\begin{array}{l}0.22 \\
0.68 \\
0.97 \\
0.73 \\
0.58 \\
0.61 \\
0.69 \\
0.46\end{array}$ \\
\hline $\begin{array}{l}25.1 \pm 3.5 \\
5.5\end{array}$ & $\begin{array}{l}25.7 \pm 3.7 \\
13.2\end{array}$ & $\begin{array}{l}25.5 \pm 3.6 \\
6.5\end{array}$ & $\begin{array}{l}0.78 \\
0.16\end{array}$ \\
\hline $\begin{array}{l}59.1 \\
20.2 \\
20.7\end{array}$ & $\begin{array}{l}63.2 \\
22.9 \\
13.9\end{array}$ & $\begin{array}{l}74.2 \\
16.1 \\
9.7\end{array}$ & 0.31 \\
\hline $\begin{array}{l}26.3 \\
35.4 \\
27.3 \\
11.0\end{array}$ & $\begin{array}{l}29.4 \\
35.7 \\
26.6 \\
8.4\end{array}$ & $\begin{array}{l}33.3 \\
40.0 \\
15.0 \\
11.7\end{array}$ & 0.34 \\
\hline
\end{tabular}

\section{Tissue Samples}

Tumour material of all CRC patients was collected after approval by the Medical Ethics Committees (MEC) of Maastricht University, the NCR and PALGA (14). Subsequently, all pathology laboratories in The Netherlands agreed to make relevant tissue samples available upon request from PALGA. Tissue samples of the 819 cases present in 54 pathology laboratories throughout The Netherlands were collected between August 1999 and December 2001. For $43(5 \%)$ untraceable tumour tissue specimens and 39 specimens (5\%) with insufficient CRC tumour material, $K$-ras mutation status could not be determined. Finally, tumour material from 737 incident colorectal adenocarcinoma cases was available of whom 476 were colon cancer cases, 85 were rectosigmoid cancer cases and 176 were rectal cancer cases. Statistical analyses were performed separately for colon and rectal cancer as differences in the aetiology of colon and rectal cancer have been reported (24). Since the rectosigmoid can be considered as a clinically applied term rather than an anatomically defined transitional zone between the colon and rectum, patients with a rectosigmoid tumour were excluded from data-analyses. Moreover, the number of patients with a rectosigmoid tumour was too small for adequate stratified analyses (14).

\section{Detection of $\boldsymbol{K}$-ras mutations}

Mutation analysis of the exon 1 fragment of the $K$-ras oncogene, spanning codons 8-29, was performed on archival colorectal adenocarcinoma specimens of all 737 CRC patients using macrodissection, nested PCR and direct sequencing of purified fragments, which has been described in detail elsewhere (14). 
Table 2 Nutrient intake (mean \pm SD) and other characteristics among rectal cancer cases and subcohort members

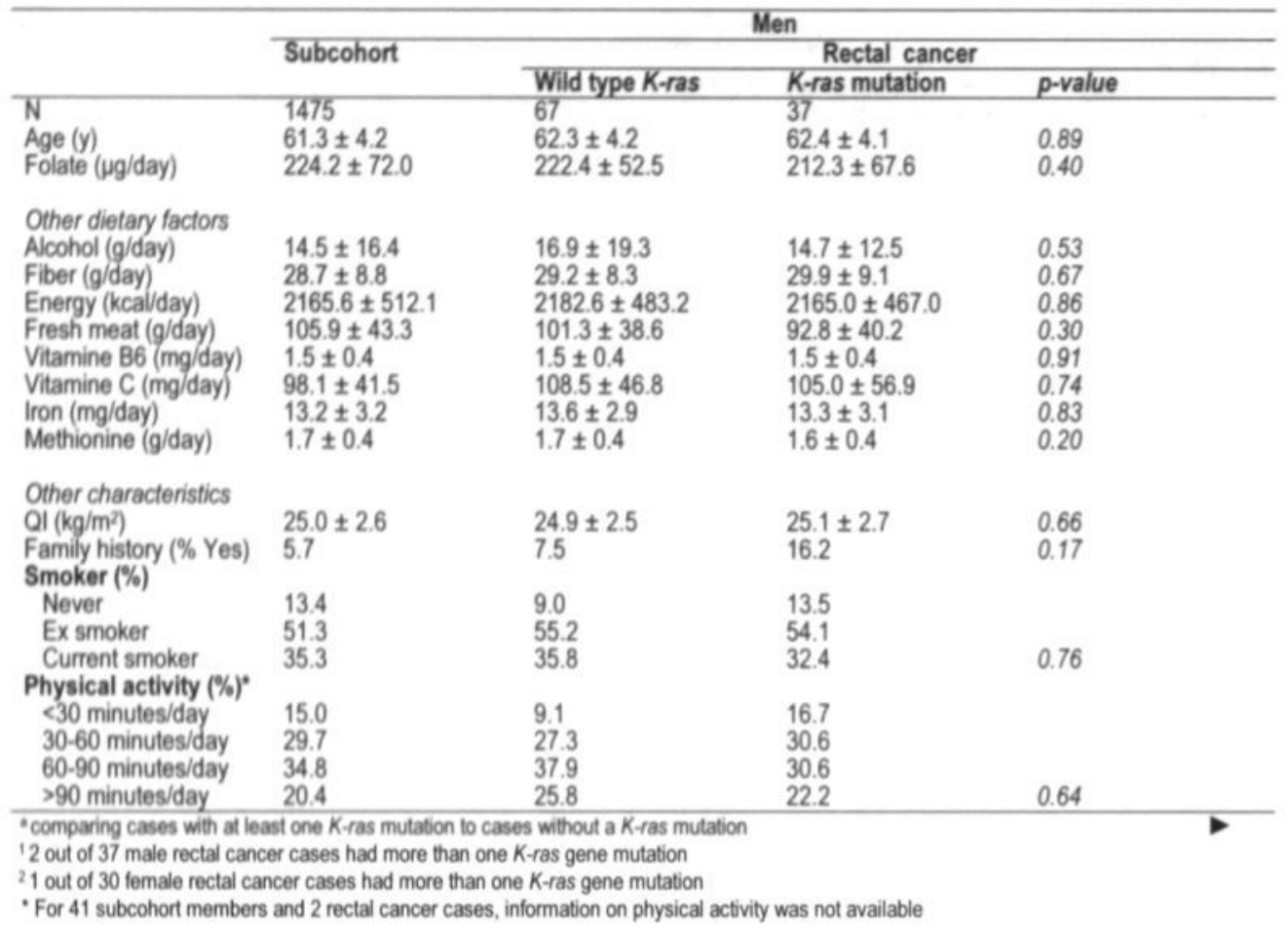

\section{The Food Frequency Questionnaire}

The dietary section of the questionnaire was a 150 -item semi-quantitative food frequency questionnaire, which concentrated on habitual consumption of food and beverages during the year preceding the start of the study. Daily mean nutrient intakes were calculated by cumulating the multiplied frequencies and portion sizes of all food items with their tabulated nutrient contents from the Dutch food composition table (25). The questionnaire was validated against a 9-day diet record (26). Questionnaire data were keyentered twice and processed for all incident cases in the cohort and for all subcohort members in a manner blinded with respect to case/subcohort status. This was done in order to minimise observer bias in coding and interpretation of the data.

Folate data were derived from a validated liquid chromatography trienzyme method (27) used to analyse the 125 most important dutch foods contributing to folate intake (28). The mean daily intakes of all other relevant nutrients were calculated using the computerized Dutch Food Composition Table (25). For data-analyses, an increment of $100 \mu \mathrm{g} / \mathrm{day}$ increase in folate intake for men and women was computed based on the current recommendations of the Dutch Health Council.

For 257 subjects (28 incident colon adenocarcinoma cases, 16 incident rectal adenocarcinoma cases and 215 subcohort members; two subcohort members were also colon or rectal cancer cases), dietary data were incomplete or inconsistent, and they were excluded from the analyses. These subjects either 1) left 60 or more (out of 150) questionnaire items blank and ate fewer than 35 items at least once per month and/or 2) left one or more item blocks (groups of items, i.e., beverages) blank. Additional details are given elsewhere (26). Hence, 608 colon (242 men and 206 women) and rectal cases (104 men 


\begin{tabular}{|c|c|c|c|}
\hline \multicolumn{4}{|c|}{ Women } \\
\hline \multirow[t]{2}{*}{ Subcohort } & \multicolumn{3}{|c|}{ Rectal cancer } \\
\hline & Wild type K-ras & K-ras mutation & p-value \\
\hline $\begin{array}{l}1573 \\
61.4 \pm 4.3 \\
199.8 \pm 64.7\end{array}$ & $\begin{array}{l}26 \\
63.5 \pm 4.0 \\
212.2 \pm 70.7\end{array}$ & $\begin{array}{l}30 \\
62.0 \pm 3.9 \\
216.2 \pm 94.8\end{array}$ & $\begin{array}{l}0.17 \\
0.86\end{array}$ \\
\hline $\begin{array}{l}5.7 \pm 9.4 \\
25.5 \pm 7.2 \\
1691.4 \pm 408.5 \\
93.8 \pm 40.4 \\
1.3 \pm 0.3 \\
108.2 \pm 43.8 \\
11.7 \pm 2.7 \\
1.5 \pm 0.4\end{array}$ & $\begin{array}{l}5.3 \pm 6.5 \\
24.2 \pm 5.9 \\
1627.0 \pm 370.6 \\
98.8 \pm 45.2 \\
1.4 \pm 0.3 \\
109.5 \pm 43.1 \\
11.6 \pm 2.2 \\
1.6 \pm 0.4\end{array}$ & $\begin{array}{l}6.6 \pm 10.3 \\
24.6 \pm 4.5 \\
1789.7 \pm 328.4 \\
99.2 \pm 32.0 \\
1.4 \pm 0.3 \\
111.3 \pm 45.8 \\
11.6 \pm 2.2 \\
1.5 \pm 0.3\end{array}$ & $\begin{array}{l}0.60 \\
0.74 \\
0.09 \\
0.97 \\
0.88 \\
0.88 \\
0.95 \\
0.63\end{array}$ \\
\hline $\begin{array}{l}25.1 \pm 3.5 \\
5.5\end{array}$ & $\begin{array}{l}25.1 \pm 3.5 \\
15.4\end{array}$ & $\begin{array}{l}26.0 \pm 3.1 \\
6.7\end{array}$ & $\begin{array}{l}0.27 \\
0.29\end{array}$ \\
\hline $\begin{array}{l}59.1 \\
20.2 \\
20.7\end{array}$ & $\begin{array}{l}69.2 \\
7.7 \\
23.1\end{array}$ & $\begin{array}{l}60.0 \\
30.0 \\
10.0\end{array}$ & 0.07 \\
\hline $\begin{array}{l}26.3 \\
35.4 \\
27.3 \\
11.0\end{array}$ & $\begin{array}{l}42.3 \\
26.9 \\
19.2 \\
11.5\end{array}$ & $\begin{array}{l}30.0 \\
23.3 \\
40.0 \\
6.7\end{array}$ & 0.39 \\
\hline
\end{tabular}

and 56 women) and 3048 subcohort members ( 1475 men and 1573 women) were available for data-analyses.

Daily intake of dietary fibre (g/day), vitamin $B_{2}\left(\mathrm{mg} /\right.$ day), vitamin $B_{6}(\mathrm{mg} /$ day), vitamin $C$ $(\mu \mathrm{g} /$ day), iron (mg/day), alcohol (g/day), fresh meat $\mathrm{g} /$ day), and total energy (kcal/day) and age at baseline (years), Quetelet Index (Ql; $\left.\mathrm{kg} / \mathrm{m}^{2}\right)$, physical activity $(<30 \mathrm{~min} / \mathrm{d}, 30-60$ $\mathrm{min} / \mathrm{d}, 60-90 \mathrm{~min} / \mathrm{d},>90 \mathrm{~min} / \mathrm{d}$ ), family history of CRC (yes/no) and smoking status (never/ex/current) were regarded as potential confounders.

\section{Statistical Analysis}

Analyses were conducted for men and women separately. The overall frequency of $K$-ras mutations as well as the type of mutation were computed for all colon and rectal cancer cases as described elsewhere (14). Mean values of the continuous variables age at baseline (years), intake of total folate, dietary fiber, alcohol, fresh meat, vegetables and total energy and QI were evaluated for subcohort members and colon and rectal cancer cases with wild-type and mutated $K$-ras gene. Differences in mean values of the continuous variables between patients with wild type and mutated $K$-ras gene were tested with the Student T-test or the Mann-Whitney-U-test if the variables were not normally distributed. Distributions of the categorical variables family history of CRC, smoking status and physical activity were evaluated for subcohort members and colon and rectal cancer patients with wild-type and mutated $K$-ras gene and tested for differences between patient groups with the $X^{2}$-test. The statistical software package SPSS (version 9) was used for these analyses.

Age-adjusted and multivariate-adjusted incidence rate ratios (RR) and their 95\% confidence intervals $(\mathrm{Cl})$ for colon and rectal cancer risk were calculated for men and women separately, using Cox regression models with the STATA statistical software package (intercooled STATA, version 7). Standard errors were estimated using the robust Huber-White sandwich estimator to account for additional variance introduced by sampling 
from the cohort. This method is equivalent to the variance-covariance estimator as presented by Barlow (29). The proportional hazards assumption was tested using the scaled Schoenfeld residuals $(30)$. Those variables that were found to contribute substantially $(p<0.10)$ to the multivariate model for colon and/or rectal cancer (age, smoking, QI, total fresh meat consumption, and intake of iron and vitamin C) were included as covariates in all multivariate analyses. Additional adjustment for dietary fiber and energy intake was performed, in line with the previous report on folate and overall colon and rectal cancer risk in the Netherlands Cohort Study (3). The personyears at risk, estimated from the subcohort, were used in the analyses.

To date, foods are not fortified with folic acid in The Netherlands. For the time being, an intake of $200 \mathrm{~g}$ of vegetables and two pieces of fruit daily is recommended. This is approximately twice the amount of fruit and vegetables found to be consumed in the Dutch National Food Consumption Survey (DNFCS) carried out in 1992. The fruit and vegetable intake accounts for approximately $50 \mu \mathrm{g}$ folate (28). We calculated RRs according to an increase in intake of $100 \mu \mathrm{g} / \mathrm{d}$ of folate. Approximately twice this additional amount would be necessary to reach the US recommended daily allowance of $400 \mu \mathrm{g} / \mathrm{d}$ in the majority of the men and women of this cohort.

\section{RESULTS}

The overall frequency and spectrum of mutations in the $K$-ras gene have been presented in detail elsewhere (14). In brief, a total of 227 mutations was found in 218 out of $608(36 \%)$ colon and rectal cancer patients. The most frequently observed mutations are the G>A transitions (54\%), G>T transversions (33\%) and $G>C$ transversions $(7 \%)$. The observed frequencies of the mutations in this series of patients are similar to the frequencies of the 737 colorectal cancer cases (including the rectosigmoid) for whom $K$-ras status was determined (14).

Table 1 shows the folate intake and other baseline characteristics for colon cancer cases and subcohort members, separately for men and women. The mean age of the subcohort members was 61.3 years for men and 61.4 years for women. Overall, colon cancer cases were older than the subcohort members. Colon cancer patients with a mutated $K$-ras gene were significantly older than the patients with a wild type $K$-ras gene ( $p$-values 0.04 and 0.06 for men and women, respectively). Dietary folate intake was higher among subcohort members as compared to the different colon cancer subgroups. No statistically significant differences for other (dietary) factors were observed for colon cancer cases without and with a $\mathrm{K}$-ras mutation in men and women as presented in table 1.

For rectal cancer cases and subcohort members, the mean folate intake and other baseline characteristics are presented in table 2. Rectal cancer patients were older than the subcohort members. Dietary folate intake among subcohort members and the different rectal cancer subgroups was similar. Women with a mutated $K$-ras rectal tumour were more often ex-smoker as compared to women with a wild type $K$-ras rectal tumour and subcohort members. No statistically significant differences for other (dietary) factors were observed for rectal cancer cases without and with a $K$-ras mutation in men and women as presented in table 2.

For colon cancer, associations between folate intake and risk of disease, as well as $K$-ras mutation status are presented for men and women in table 3 . No significant association was observed between dietary folate and overall colon cancer risk or with the K-ras mutation status after adjustment for age, QI, smoking, alcohol, fresh meat, energy intake and family history of CRC, iron intake, vitamin C intake and dietary fibre. 
Table 3 Incidence rate ratios (RR) and 95\% confidence intervals $(\mathrm{Cl})$ for colon cancer patients overall and with a (specific) $K$-ras mutation status $(\mathrm{N}=448)$ according to dietary folate intake

\begin{tabular}{|c|c|c|c|c|}
\hline & \multicolumn{4}{|c|}{$\begin{array}{c}R R(95 \% \mathrm{Cl}) \text { per increment of } 100 \mu g / \text { day increase of } \\
\text { dietary folate intake }\end{array}$} \\
\hline & $\mathbf{N}$ & Men & $\mathbf{N}$ & Women \\
\hline \multicolumn{5}{|l|}{ colon cancer } \\
\hline$R^{\prime}$ & 231 & $1.08(0.91-1.30)$ & 199 & $0.87(0.67-1.15)$ \\
\hline$R^{2}$ & 231 & $0.87(0.66-1.14)$ & 199 & $0.98(0.62-1.56)$ \\
\hline \multicolumn{5}{|l|}{ K-ras } \\
\hline$R R^{2}$ & 148 & $0.94(0.69-1.27)$ & 141 & $0.89(0.52-1.52)$ \\
\hline \multicolumn{5}{|l|}{ K-ras } \\
\hline $\mathbf{R R}^{2}$ & 83 & $0.76(0.47-1.22)$ & 58 & $1.22(0.52-2.82)$ \\
\hline \multicolumn{5}{|l|}{$G>A^{*}$} \\
\hline $\mathrm{RR}^{2}$ & 47 & $0.78(0.40-1.53)$ & 34 & $1.29(0.48-3.49)$ \\
\hline \multicolumn{5}{|l|}{$\mathrm{G}>\mathrm{T} \cdot \mathrm{G}>\mathrm{C}^{*}$} \\
\hline$R^{2}{ }^{2}$ & 29 & $0.77(0.41-1.45)$ & 25 & $1.56(0.49-4.95)$ \\
\hline
\end{tabular}

'RR adjusted for age

${ }^{2} R R$ adjusted for age, Q1, smoking, alcohol, fresh meat, energy intake and family history of CRC, vitamin C, iron, fiber

For rectal cancer, associations between folate intake and risk of disease overall, as well as $K$-ras mutation status are presented for men and women in table 4. A significant, inverse association was observed between folate and overall rectal cancer risk in men (RR 0.58 , $95 \% \mathrm{Cl} 0.36-0.93$ ), as well as with a $K$-ras mutation in the tumour ( $R \mathrm{R} 0.40,95 \% \mathrm{Cl} 0.17$ 0.89 ). The association was strongest for $\mathrm{G}>\mathrm{T}$ or $\mathrm{G}>\mathrm{C}$ transversions in the $K$-ras gene (RR $0.19,95 \% \mathrm{Cl} 0.03-1.07$ ). For women, a significant positive association was observed between folate and overall rectal cancer risk (RR 1.85, 95\% Cl 1.13-3.02) and this association was observed for rectal tumours without and with a $K$-ras oncogene mutation (RR 1.94, 95\% Cl 1.03-3.66 and 1.83, 95\% Cl 0.91-3.68, respectively). After taking into account the specific point mutations in the $K$-ras gene, an increased risk was observed for rectal tumours harbouring $G>T$ or $G>C$ transversions (RR 2.69, 95\% Cl 1.43-5.09). However, a significant inverse association was observed between folate and $G>A$ transitions (RR $0.08,95 \% \mathrm{Cl} 0.01-0.53$ ).

Table 4 Incidence rate ratios (RR) and 95\% confidence intervals $(\mathrm{CI})$ for rectal cancer patients overall and with a (specific) $K$-ras mutation status $(\mathrm{N}=160)$ according to dietary folate intake

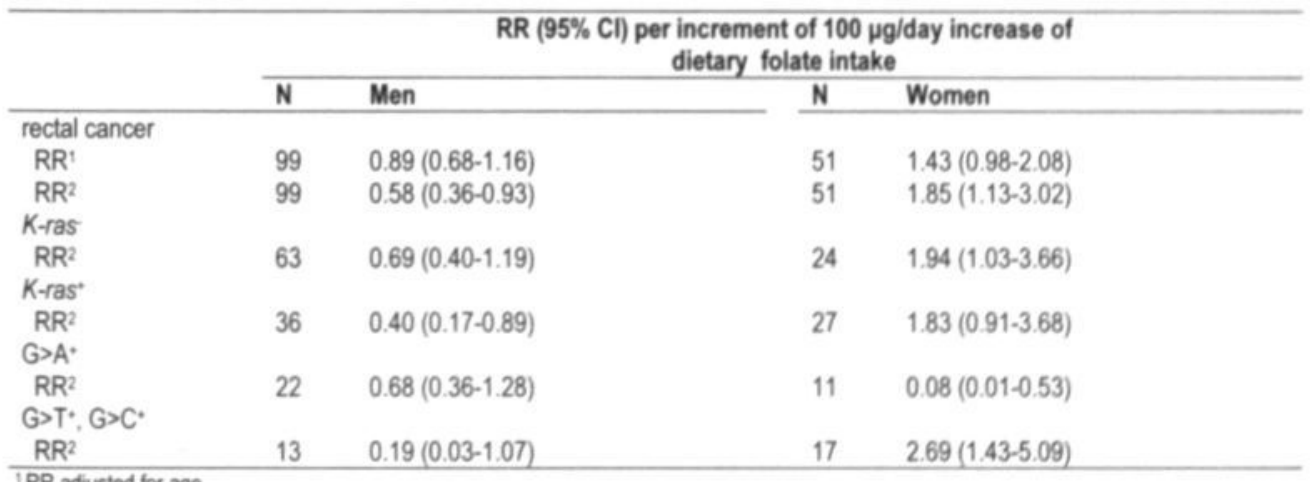

'RR adjusted for age

2RR adjusted for age, OI, smoking, alcohol, fresh meat, energy intake and family history of CRC, vitamin C, iron, fiber 


\section{DISCUSSION}

In a large cohort with 448 incident colon cancer patients and 160 incident rectal cancer patients, no significant associations were observed between folate intake and the risk of colon cancer in men and women, either overall or after the $K$-ras mutation status was taken into account. For men, a protective effect was observed for folate and rectal cancer risk, overall and most pronounced, with $K$-ras mutated tumours. For women, however, an increased association was observed between folate and rectal cancer risk, overall and also when the $K$-ras mutation status was taken into account. Regarding the specific point mutations in the $K$-ras gene of rectal tumours in women, dietary folate was positively associated with $G>T$ or $G>C$ transversions, however, inversely associated with $G>A$ transitions.

The current cohort study on folate intake and specific $K$-ras mutations is, to our knowledge, the only prospective study performed to date taking into account the $K$-ras mutation status. The prospective design of this study and high completeness of follow-up of cancer incidence and subcohort make information and selection bias unlikely. In addition, as a result of the exclusion of the first 2.3 years of follow-up, the chance of information bias due to potential preclinical CRC is minimal.

Although several epidemiological studies have been conducted on dietary factors and $K$-ras mutations in colon and rectal cancer, only three have reported on folate intake, i.e one large case-control study with colon cancer patients (17), one case-control study with colon and rectal cancer patients (20) and one cross-sectional case-case study with colorectal adenoma patients (7). Slattery et al (17) observed a statistically significant inverse association between low dietary folate intake and the risk of colon tumours with a wild type $K$-ras gene (odds ratio (OR) for the lowest versus the highest tertile of intake $1.4,95 \% \mathrm{Cl}$ 1.1-1.8; $\left.p_{\text {trend }}<0.01\right)$. In another smaller case-control study with colon and rectal cancer patients, no statistical differences in dietary folate intake as observed between cases with a K-ras mutation compared to cases with a wild type K-ras (18). Therefore, case-control analyses regarding dietary folate intake was not further explored in the study by Bautista et al (18). In a large case-case comparison of colorectal adenoma patients (7), individuals in the upper tertile of total folate intake (dietary and supplemental folate), compared with individuals in the lowest tertile, had a nearly $50 \%$ lower risk of having $K$-ras mutation-positive adenomas (OR $0.52,95 \% \mathrm{Cl} 0.30-0.88$; $\mathrm{p}_{\text {trend }} 0.02$ ). This reduction in risk of $K$-ras mutationpositive adenomas was not observed for dietary folate intake alone (OR $0.91,95 \% \mathrm{Cl} 0.50-$ $1.64 ; p_{\text {trend }} 0.75$ ). Caution is warranted in interpreting these results, because case-case comparisons, including both male and female colon and rectal adenomas, were performed. Case-case comparisons are valuable for the estimation of etiologic heterogeneity with regard to $K$-ras mutation status. However, they do not give information on the direction of the association between folate and $K$-ras wild type or mutated tumours, respectively. This can only be obtained with case-control comparisons. In addition, we observed distinct differences in associations between men and women and colon and rectal cancer. Our results do not support the protective effect of folate for mutated $K$-ras colon tumours observed in the other studies. One explanation could be that dietary folate intake in The Netherlands is too low to evoke its potentially protective effect in colon and rectal cancer, although a protective effect was observed for male rectal cancer. In the NLCS, $22 \%$ of the study population used vitamin B supplements in 1986 (31). However, due to legislative restrictions in The Netherlands, it was not allowed until 1994 to use folic acid in vitamin supplements. Therefore, the overall effect of folic acid supplements in this cohort is presumably negligible.

In the current study, an inverse association was observed for both men and women between high folate intake and rectal tumours harbouring a G>A transition in the $K$-ras 
oncogene. This was also observed by Slattery et al (17), although not statistically significant, for $\mathrm{G}>\mathrm{A}$ transitions at the second position of codon 12 (OR for lowest tertile versus highest tertile of intake $0.7,95 \% \mathrm{Cl} 0.4-1.3 ; p_{\text {rend }} 0.11$ ). This could be an indirect consequence of promotor hypermethylation of mismatch repair genes, like the $O^{6}$-methylguanine DNA methyltransferase (MGMT) gene. Van Engeland et al (10) evaluated the association between promoter hypermethylation of genes involved in colorectal carcinogenesis, like MGMT, and folate and alcohol intake within the framework of the NLCS. MGMT is a DNA repair protein that removes adducts from the $0^{6}$ position of guanine (32) in DNA, thereby preventing G>A or C>T mutations. Despite the limited size of the study performed by van Engeland et al (10), the data suggest that low folate and high alcohol intakes may be associated with promoter hypermethylation in genes involved in CRC, i.e. MGMT. No clear associations were observed for folate and G>A transitions in men, either in the colon or the rectum. More aetiological insight in the underlying mechanisms relating the differences in tumour site, gender and $K$-ras mutation status in CRC is required to clarify this issue. Moreover, due to the overall small number of cases when studying subgroups of $K$-ras mutated tumours, the results of this study should be interpreted with caution, and need replication in future larger studies.

We observed an increased risk of rectal cancer with increased folate intake in women. This was observed for both wild type and mutated $K$-ras gene, i.e. G>T and $G>C$ transversions, but not for $\mathrm{G}>\mathrm{A}$ transitions as described above. For men, however, an inverse association with $\mathrm{G}>\mathrm{T}$ and $\mathrm{G}>\mathrm{C}$ transversions in rectal tumours was observed. Another recent study also showed elevated risks for rectal cancer in women with increased dietary folate intake, though not statistically significant (4). With the folate food fortifications and extensive use of (multi)vitamin supplements including folate in different countries, it is important to further investigate this issue in prospective studies.

In conclusion, in this study dietary folate is not significantly associated with colon cancer risk, either overall or with the $K$-ras mutation status. Moreover, our data suggest that the effect of high folate intake on rectal cancer risk is different for men and women, and depends on the $K$-ras mutation status of the tumour.

\section{REFERENCES}

1. Giovannucci E. (2002) Epidemiologic studies of folate and colorectal neoplasia: a review. J Nutr, 132(8 Suppl), 2350S-2355S.

2. Potter JD. (2002) Methyl supply, methyl metabolizing enzymes and colorectal neoplasia. J Nutr, 132(8 Suppl), 2410S-2412S.

3. Konings EJ, Goldbohm RA, Brants HA, Saris WH, van den Brandt PA. (2002) Intake of dietary folate vitamers and risk of colorectal carcinoma: results from The Netherlands Cohort Study. Cancer, 95(7), 1421-33.

4. Wei EK, Giovannucci E, Wu K, et al. (2004) Comparison of risk factors for colon and rectal cancer. Int.J.Cancer, 108, 433-442.

5. Little J. (2001) Multivitamins, folate, and colon cancer. Gut, 48(1), 12-3.

6. Fallon UB. (2003) Commentary: Colon cancer, folate and genetic status. Int $J$ Epidemiol, 32(1), 67-70.

7. Martinez ME, Maltzman T, Marshall JR, et al. (1999) Risk factors for Ki-ras protooncogene mutation in sporadic colorectal adenomas. Cancer Res, 59(20), 5181-5.

8. Povey AC, Badawi AF, Cooper DP, et al. (2002) DNA alkylation and repair in the large bowel: animal and human studies. J Nutr, 132(11 Suppl), 3518S-3521S.

9. Esteller M, Toyota M, Sanchez-Cespedes M, et al. (2000) Inactivation of the DNA repair gene O6-methylguanine-DNA methyltransferase by promoter hypermethylation is 
associated with $\mathrm{G}$ to $\mathrm{A}$ mutations in K-ras in colorectal tumorigenesis. Cancer Res, 60(9), 2368-71.

10. van Engeland M, Weijenberg MP, Roemen GM, et al. (2003) Effects of dietary folate and alcohol intake on promoter methylation in sporadic colorectal cancer: the Netherlands cohort study on diet and cancer. Cancer Res, 63(12), 3133-7.

11. Vogelstein B, Fearon ER, Hamilton SR, et al. (1988) Genetic alterations during colorectal-tumor development. N Engl J Med, 319(9), 525-32.

12. Bos JL, Fearon ER, Hamilton SR, et al. (1987) Prevalence of ras gene mutations in human colorectal cancers. Nature, 327(6120), 293-7.

13. Breivik J, Meling GI, Spurkland A, Rognum TO, Gaudernack G. (1994) K-ras mutation in colorectal cancer: relations to patient age, sex and tumour location. $\mathrm{Br} J$ Cancer, 69(2), 367-71.

14. Brink M, De Goeij AF, Weijenberg MP, et al. (2003) K-ras oncogene mutations in sporadic colorectal cancer in The Netherlands Cohort Study. Carcinogenesis, 24(4), 703-710.

15. Martinez-Garza SG, Nunez-Salazar A, Calderon-Garciduenas AL, Bosques-Padilla FJ, Niderhauser-Garcia A, Barrera-Saldana HA. (1999) Frequency and clinicopathology associations of K-ras mutations in colorectal cancer in a northeast Mexican population. Dig Dis, 17(4), 225-9.

16. Urosevic N, Krtolica K, Skaro-Milic A, Knezevic-Usaj S, Dujic A. (1993) Prevalence of G-to-T transversions among K-ras oncogene mutations in human colorectal tumors in Yugoslavia. Int J Cancer, 54(2), 249-54.

17. Slattery ML, Curtin K, Anderson K, et al. (2000) Associations between dietary intake and Ki-ras mutations in colon tumors: a population-based study. Cancer Res, 60(24), 6935-41.

18. Bautista D, Obrador A, Moreno V, et al. (1997) Ki-ras mutation modifies the protective effect of dietary monounsaturated fat and calcium on sporadic colorectal cancer. Cancer Epidemiol Biomarkers Prev, 6(1), 57-61.

19. van den Brandt PA, Goldbohm RA, van 't Veer P, Volovics A, Hermus RJ, Sturmans F. (1990) A large-scale prospective cohort study on diet and cancer in The Netherlands. $J$ Clin Epidemiol, 43(3), 285-95.

20. van den Brandt PA, Schouten LJ, Goldbohm RA, Dorant E, Hunen PM. (1990) Development of a record linkage protocol for use in the Dutch Cancer Registry for Epidemiological Research. Int J Epidemiol, 19(3), 553-8.

21. Schouten LJ, Jager JJ, van den Brandt PA. (1993) Quality of cancer registry data: a comparison of data provided by clinicians with those of registration personnel. $\mathrm{Br} J$ Cancer, 68(5), 974-7.

22. Schouten LJ, Straatman H, Kiemeney LA, Gimbrere $\mathrm{CH}$, Verbeek AL. The capturerecapture method for estimation of cancer registry completeness: a useful tool? Int $J$ Epidemiol, 23(6), 1111-6.

23. van der Sanden GA, Coebergh JW, Schouten LJ, Visser O, van Leeuwen FE. (1995) Cancer incidence in The Netherlands in 1989 and 1990: first results of the nationwide Netherlands cancer registry. Coordinating Committee for Regional Cancer Registries. Eur J Cancer, 31A(11), 1822-9.

24. Potter JD. (1996) Nutrition and colorectal cancer. Cancer Causes Control, 7(1), 127-46.

25. Nevo table. (1986) Dutch food composition table 1986-1987.

26. Goldbohm RA, van den Brandt PA, Brants HA, et al. (1994) Validation of a dietary questionnaire used in a large-scale prospective cohort study on diet and cancer. Eur $J$ Clin Nutr, 48(4), 253-65.

27. Konings EJ. (1999) A validated liquid chromatographic method for determining folates in vegetables, milk powder, liver, and flour. J AOAC Int, 82(1), 119-27.

28. Konings EJ, Roomans HH, Dorant E, Goldbohm RA, Saris WH, van den Brandt PA. (2001) Folate intake of the Dutch population according to newly established liquid chromatography data for foods. Am J Clin Nutr, 73(4), 765-76. 
29. Barlow WE, Ichikawa L, Rosner D, Izumi S. (1999) Analysis of case-cohort designs. J Clin Epidemiol, 52(12), 1165-72.

30. Schoenfeld D. (1982) Partial residuals for the proportional hazards regression model. Biometrika, 69, 239-241.

31. Dorant E, van den Brandt PA, Goldbohm RA. (1994) A prospective cohort study on Allium vegetable consumption, garlic supplement use, and the risk of lung carcinoma in The Netherlands. Cancer Res, 54(23), 6148-53.

32. Toft NJ, Arends MJ. (1998) DNA mismatch repair and colorectal cancer. $J$ Pathol, 185(2), 123-9. 


\section{General Discussion}




\section{INTRODUCTION}

In this molecular epidemiological investigation, alterations in the $K$-ras oncogene were studied with respect to their frequency and relation to dietary risk factors in sporadic colorectal adenocarcinomas. In the current chapter, the findings and methodology of other relevant molecular epidemiological studies and our study on $K$-ras, dietary factors and CRC are compared and its merits are discussed. Current epidemiological evidence, including the results of this thesis, on meat, fat and folate in the diet in relation to $K$-ras mutations in colorectal tumours is summarized in tables 1,2 and 3. Next, the strengths and limitations of epidemiological studies incorporating molecular endpoints will be discussed. Finally, the implications for the interpretation of our findings and for future research will be addressed.

\section{EPIDEMIOLOGICAL EVIDENCE FOR ASSOCIATIONS BETWEEN DIETARY FACTORS AND $K$-RAS MUTATIONS IN COLORECTAL CANCER}

\section{The current evidence}

The molecular epidemiological investigations conducted to date include two cross sectional studies $(1,2)$, three case-control studies (3-5), and our prospective cohort study. The main findings of these studies are presented in tables 1, 2 and 3.

Red meat was not related to the K-ras status, of either colorectal adenomas (1) or colorectal carcinomas (2) (table 1) in the cross-sectional studies. In addition, Slattery et al (4) did not observe a significant association between red meat or processed meat and the risk of colon cancer with or without $K$-ras mutations (table 6.1) within a case-control study. In case-case comparisons within the case-control study by Kampman et al (3), the consumption of poultry was associated with a 15 -fold increased risk of $K$-ras mutations in codon 12 compared with mutations in codon 13. To further evaluate the observed aetiological heterogeneity between codons 12 and 13 for poultry consumption, these authors compared both case groups with a population-based control group. A non-significant, positive association was observed with codon 12 mutations (OR 1.2, 95\% $\mathrm{Cl}$ 0.8-1.6), whereas a non-significant, inverse association was found with codon 13 mutations (OR 0.4 , $95 \% \mathrm{Cl} 0.1-1.2)$. No substantial differences in $K$-ras mutation status were observed with regard to the consumption of total red meat, beef, processed meat and fish. Our results (table 6.1 and chapter 3), on the other hand, suggest that beef, pork and meat products exert their effect via another route than the $K$-ras signalling pathway, since associations were mainly observed with wild type $K$-ras.

The associations between total fat and specific fatty acids and the risk of $K$-ras mutations in CRC risk were studied by Martinez et al (1), Bautista et al (5), Kampman et al (3), Slattery et al (4) and Brink et al (6) (table 2). Except for Bautista et al (5), none of the cross-sectional or case-control studies $(1,3)$ reported significant associations between total fat and the K-ras mutation status in CRC. A strong association for total fat and monounsaturated fat (MUFA) with an increased risk of mutated $K$-ras tumours was observed for $K$-ras mutated CRC patients compared to wild type K-ras CRC patients (5). Results from case-control analyses showed that the strong associations with total fat and MUFA were restricted to CRC patients bearing a wild type $K$-ras gene, i.e. there was a significant protective effect of MUFA on wild type $K$-ras tumours. These associations were not reported in the other studies $(1,3)$. In addition, no associations were observed between total fat and MUFA and $K$-ras mutation status in the current study (table 2). The study by Bautista et al (5) was conducted in Spain where olive oil is the main source of oleic acid and thus of MUFA. This is not the case for the current cohort and this could be an explanation for the different findings. Results from our study indicate an increased association between the risk 
Table 1 Main findings of the molecular epidemiological studies on the associations between the consumption of meat, meat products and fish, and $K$-ras mutations in sporadic CRC

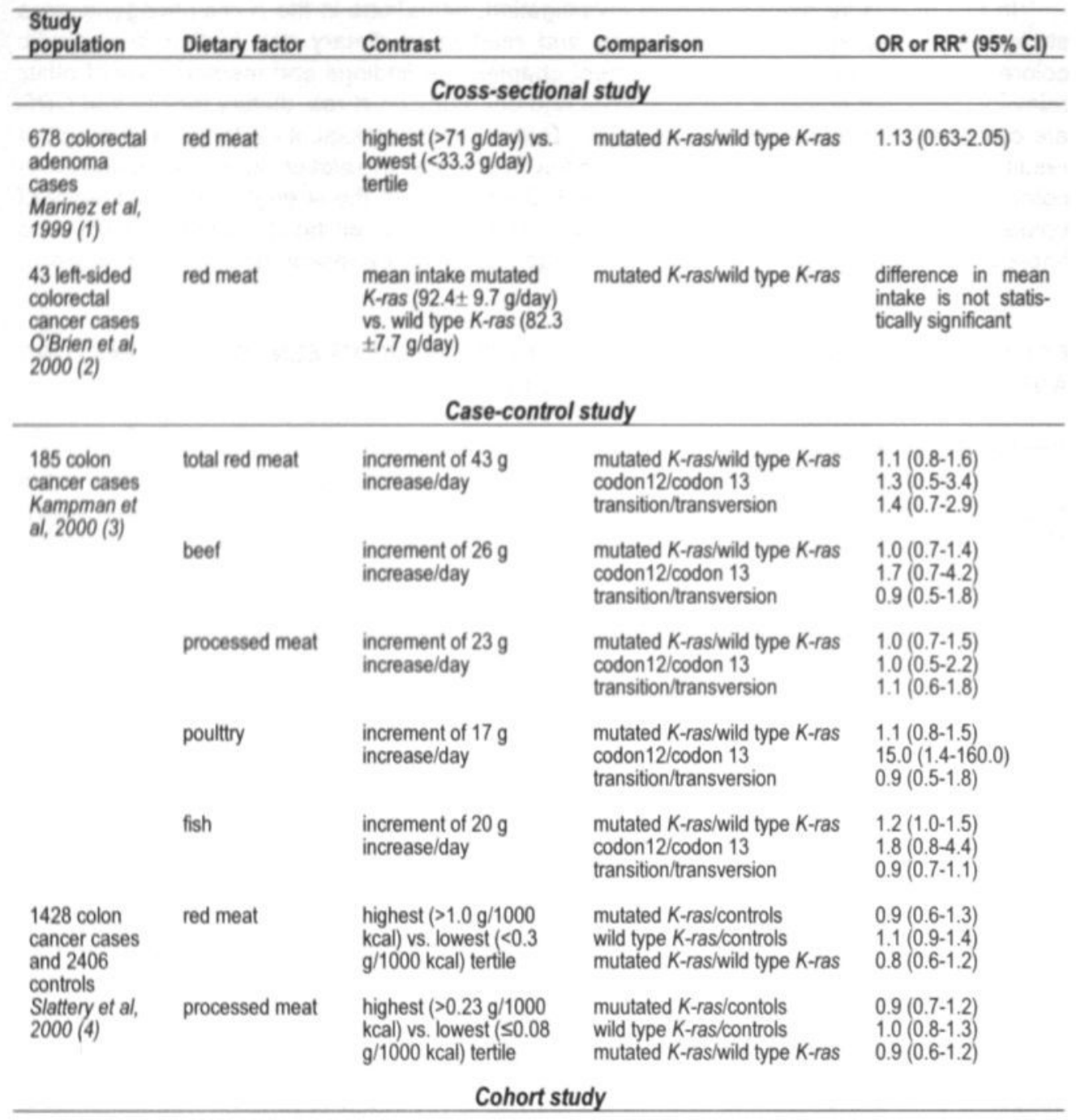

608 incident colon and rectal cancer cases and 2948 subcohort members Brink et al, $2004(6)^{*}$ total fresh meat (beef, pork, minced meat. liver, chicken, other meat)'

meat products highest (150.8 g/day) vs. lowest $(61.0 \mathrm{~g} /$ day $)$ quartile for men. highest (139.2 g/day) vs. lowest ( $50.7 \mathrm{~g} /$ day $)$ quartile for women

highest ( $33.3 \mathrm{~g} /$ day) vs. lowest ( $1.0 \mathrm{~g} /$ day) quartile for men, highest ( $22.4 \mathrm{~g} /$ day) vs. lowest $(0.0 \mathrm{~g} /$ day) quartile for women
Colon

wild type $K$-ras/subcohort $\quad 0.94(0.65-1.36)$ mutated $K$-ras/subcohort $\quad 1.01(0.61-1.66)$

Rectum

wild type $K$-ras/subcohort $\quad 0.76(0.41-1.44)$ mutated K-ras/subcohort $\quad 0.68(0.31-1.47)$

Colon

wild type K-ras/subcohort $\quad 1.42(1.00-2.03)$ mutated $K$-ras/subcohort $\quad 0.77(0.45-1.32)$

Rectum

wild type $K$-ras/subcohort $\quad 0.84(0.45-1.58)$ mutated $K$-ras/subcohort $\quad 1.41(0.67-2.99)$ 


\begin{tabular}{|c|c|c|c|c|}
\hline $\begin{array}{l}\text { Study } \\
\text { population }\end{array}$ & Dietary factor & Contrast & Comparison & OR or RR* $(95 \% \mathrm{Cl})$ \\
\hline \multicolumn{5}{|c|}{ Cohort study } \\
\hline $\begin{array}{l}608 \text { incident } \\
\text { colon and } \\
\text { rectal cancer } \\
\text { cases and } \\
2948 \\
\text { subcohort } \\
\text { members } \\
\text { Brink et al, } \\
2004(6)^{*}\end{array}$ & fish & $\begin{array}{l}\text { highest ( } 30.5 \text { g/day) vs. } \\
\text { lowest ( } 0.0 \text { g/day) } \\
\text { quartile for men, } \\
\text { highest ( } 28.2 \text { g/day) vs. } \\
\text { lowest ( } 0.0 \text { g/day) } \\
\text { quartile for women }\end{array}$ & $\begin{array}{l}\text { Colon } \\
\text { wild type } K \text {-ras/subcohort } \\
\text { mutated } K \text {-ras/subcohort } \\
\text { Rectum } \\
\text { wild type } K \text {-ras/subcohort } \\
\text { mutated } K \text {-ras/subcohort }\end{array}$ & $\begin{array}{l}0.87\left(\begin{array}{l}0.60-1.26) \\
1.38(0.85-2.25)\end{array}\right. \\
1.06(0.58-1.94) \\
0.78(0.37-1.65)\end{array}$ \\
\hline
\end{tabular}

of colon tumours with a mutated $K$-ras gene and $\omega-6$ PUFA intake, in particular linoleic acid (table 2). Moreover, these associations were also observed for $G>A$ transitions and $G>T$ and $\mathrm{G}>\mathrm{C}$ transversions in the $K$-ras gene (chapter 4). To our knowledge, the association between $\omega-6$ PUFA, in particular linoleic acid, and $K$-ras mutation status and the specific $K$-ras point mutations has not been investigated previously in CRC.

For total (dietary+supplemental) folate intake (table 3), Martinez et al (1) observed a substantial inverse association for the risk of colorectal adenomas with a mutated $K$-ras gene as compared to adenomas with a wild type K-ras gene, but these authors did not observe an association for dietary folate alone (table 3). Slattery et al (4) found that a low intake of dietary folate was associated with an increased risk of wild type $K$-ras colon tumours versus controls. No association was observed for mutated $K$-ras colon tumours versus controls. However, low intake of dietary folate was associated with an inverse risk of $\mathrm{G}>\mathrm{A}$ transitions in codon 12 of the $K$-ras gene in colon tumours versus wild type $K$-ras colon tumours. In the current study, an inverse association was seen for dietary folate and mutated $K$-ras rectal tumours in men, whereas an increased association was found for women (table 3 and chapter 5 ). For men, this inverse association was observed for $G>A$ transitions as well as $\mathrm{G}>\mathrm{T}$ or $\mathrm{G}>\mathrm{C}$ transversions (chapter 5). For women, the increased association was confined to $\mathrm{G}>\mathrm{T}$ or $\mathrm{G}>\mathrm{C}$ transversions, whereas an inverse association was observed for $\mathrm{G}>\mathrm{A}$ transitions.

\section{Case-case comparisons versus case-control comparisons}

In reviewing the molecular epidemiological evidence, as summarised in tables 1 to 3 , it is important to distinguish between results based on case-case comparisons and casecontrol/subcohort comparisons. Although case-case comparisons may give information on the degree of heterogeneity of risk factors between cases with a mutated $K$-ras tumour and cases with a wild type $K$-ras tumour, these comparisons can not give any information on the risk of mutated $K$-ras or wild type $K$-ras tumours versus a control group, i.e. a non-case group. Case-case comparisons may give clues as to whether risk factors differ for subgroups, but additional case-control/subcohort comparisons are necessary to elucidate the direction and strength of associations. For example, Bautista et al (5) observed a strong association for MUFA intake with mutated $K$-ras CRC cases versus wild type $K$-ras cases. However, additional case-control analyses were conducted and showed an inverse association between MUFA and the risk of wild type $K$-ras colorectal tumours, whereas no significant association with the risk of mutated $K$-ras tumours was found. Thus, MUFA appears to be a protective factor for wild type $K$-ras CRC cases, whereas it has no effect on $K$-ras mutated CRC cases. Thus, the case-case comparisons could be misleading if casecontrol comparisons are not presented. 
The choice of dietary factors evaluated in the current thesis was based on biological mechanisms enumerating from previous experimental and molecular epidemiological studies (see chapters 3 through 5). Biological mechanisms for meat, fat and dietary folate in relation to $K$-ras mutations as described in the literature support the associations that we found between these dietary factors and the risk of colorectal tumours with a $K$-ras mutation (chapters 3 through 5). With respect to wild type $K$-ras tumours, inverse associations were observed in two prior studies for folate (4) and MUFA (5). None of the other molecular epidemiological studies presented associations between the dietary factors under study and the risk of wild type $K$-ras tumours (1-3). Therefore, in order to evaluate the differential effects of dietary factors on the risk of tumours with and without a $K$-ras mutation, casecohort analyses were performed for these different categories of cases.

\section{STRENGHTS AND LIMITATIONS OF EPIDEMIOLOGICAL STUDIES INCORPORATING MOLECULAR ENDPOINTS}

The degree of coverage and completeness of the follow-up will be discussed in order to

Table 2 Main findings of the molecular epidemiological studies on the associations between fat intake and $K$-ras mutations in sporadic CRC

\begin{tabular}{|c|c|c|c|c|}
\hline $\begin{array}{l}\text { Study } \\
\text { population }\end{array}$ & Dietary factor & Contrast & Comparison & OR or $\operatorname{RR}^{*}(95 \% \mathrm{Cl})$ \\
\hline \multicolumn{5}{|c|}{ Cross-sectional study } \\
\hline \multirow{2}{*}{$\begin{array}{l}678 \text { colorectal } \\
\text { adenoma cases } \\
\text { Marinez et al, } \\
1999 \text { (1) }\end{array}$} & total fat & $\begin{array}{l}\text { highest ( }>823 \mathrm{~g} / \text { day }) \\
\text { vs. lowest ( }<55.5 \mathrm{~g} / \text { day) } \\
\text { tertile }\end{array}$ & mutated $K$-ras/wild type $K$-ras & $1.55(0.76-3.16)$ \\
\hline & saturated fat & $\begin{array}{l}\text { highest (>27.2 g/day) } \\
\text { vs. lowest ( } \leqslant 18.0 \mathrm{~g} / \text { day) } \\
\text { tertile }\end{array}$ & mutated $K$-ras/wild type $K$-ras & $1.06(0.54-2.07)$ \\
\hline \multicolumn{5}{|c|}{ Case-control study } \\
\hline \multirow{4}{*}{$\begin{array}{l}108 \text { colorectal } \\
\text { cancer cases and } \\
295 \text { controls } \\
\text { Bautista et al, } \\
1997 \text { (5) }\end{array}$} & total fat & highest vs. lowest tertile & $\begin{array}{l}\text { mutated } K \text {-ras/wild type } K \text {-ras } \\
\text { mutated } K \text {-ras/controls } \\
\text { wild type } K \text {-ras/controls }\end{array}$ & $\begin{array}{l}3.04(0.95-9.76) \\
1.4(0.55-3.7) \\
0.47(0.22-0.99)\end{array}$ \\
\hline & MUFA & highest vs. lowest tertile & $\begin{array}{l}\text { mutated } K \text {-ras/wild type } K \text {-ras } \\
\text { mutated } K \text {-ras/controls } \\
\text { wild type } K \text {-ras/controls }\end{array}$ & $\begin{array}{l}10.71(2.84-40.4) \\
1.6(0.63-4.2) \\
0.25(0.10-0.60)\end{array}$ \\
\hline & PUFA & highest vs. lowest tertile & $\begin{array}{l}\text { mutated } K \text {-ras/wild type } K \text {-ras } \\
\text { mutated } K \text {-ras/controls } \\
\text { wild type } K \text {-ras/controls }\end{array}$ & $\begin{array}{l}0.73(0.25-2.18) \\
0.46(0.18-1.2) \\
0.86(0.43-1.7)\end{array}$ \\
\hline & saturated fat & highest vs. lowest tertile & $\begin{array}{l}\text { mutated } K \text {-ras/wild type } K \text {-ras } \\
\text { mutated } K \text {-ras/controls } \\
\text { wild type } K \text {-ras/controls }\end{array}$ & $\begin{array}{l}0.53(0.16-1.71) \\
0.90(0.34-2.4) \\
0.79(0.38-1.7)\end{array}$ \\
\hline \multirow{2}{*}{$\begin{array}{l}185 \text { colon cancer } \\
\text { cases } \\
\text { Kampman et al } \\
2000 \text { (3) }\end{array}$} & total fat & $\begin{array}{l}\text { increment of } 20 \mathrm{~g} \\
\text { increase/day }\end{array}$ & $\begin{array}{l}\text { mutated } K \text {-ras/wild type } K \text {-ras } \\
\text { codon } 12 / \text { codon } 13 \\
\text { transition/transversion }\end{array}$ & $\begin{array}{l}1.2(0.9-1.6) \\
1.2(0.6-2.3) \\
0.9(0.6-1.4)\end{array}$ \\
\hline & saturated fat & $\begin{array}{l}\text { increment of } 16 \mathrm{~g} \\
\text { increase/day }\end{array}$ & $\begin{array}{l}\text { mutated } K \text {-ras/wild type } K \text {-ras } \\
\text { codon } 12 / \text { codon } 13 \\
\text { transition/transversion }\end{array}$ & $\begin{array}{l}1.1(0.8-1.4) \\
1.4(0.7-2.6) \\
1.1(0.7-1.6)\end{array}$ \\
\hline
\end{tabular}




\begin{tabular}{|c|c|c|c|c|}
\hline $\begin{array}{l}\text { Study } \\
\text { population }\end{array}$ & Dietary factor & Contrast & Comparison & OR or RR* \\
\hline \multicolumn{5}{|c|}{ Case-control study } \\
\hline \multirow{4}{*}{$\begin{array}{l}1428 \text { colon } \\
\text { cancer cases and } \\
2406 \text { controls } \\
\text { Slattery et al, } \\
2000 \text { (4) }\end{array}$} & total fat & $\begin{array}{l}\text { highest }(>40.0 \mathrm{~g} / 1000 \\
\text { kcal) vs. lowest }(\leq 30.0 \\
\mathrm{g} / 1000 \mathrm{kcal}) \text { tertile }\end{array}$ & $\begin{array}{l}\text { mutated } K \text {-rasicontrols } \\
\text { wild type } K \text {-rasicontrols } \\
\text { mutated } K \text {-rasiwild type } K \text {-ras }\end{array}$ & $\begin{array}{l}1.1(0.8-1.5) \\
1.0(0.8-1.2) \\
1.2(0.8-1.7)\end{array}$ \\
\hline & saturated fat & $\begin{array}{l}\text { highest ( }>15.0 \mathrm{~g} / 1000 \\
\mathrm{kcal} \text { vs. lowest ( } \mathrm{S10.0} \\
\mathrm{g} / 1000 \mathrm{kcal}) \text { tertile }\end{array}$ & $\begin{array}{l}\text { mutated } K \text {-rasicontols } \\
\text { wild type } K \text {-rasicontrols } \\
\text { mutated } K \text {-rasiwild type } K \text {-ras }\end{array}$ & $\begin{array}{l}1.1(0.8-1.5) \\
0.8(0.7-1.1) \\
1.3(0.9-1.9)\end{array}$ \\
\hline & MUFA & $\begin{array}{l}\text { highest (>14.2 g/1000 } \\
\text { kcal) vs. lowest ( } 511.0 \\
\mathrm{~g} / 1000 \mathrm{kcal}) \text { tertile }\end{array}$ & $\begin{array}{l}\text { mutated } K \text {-rasicontrols } \\
\text { wild type } K \text {-ras/controls } \\
\text { mutated } K \text {-ras/wild type } K \text {-ras }\end{array}$ & $\begin{array}{l}1.1(0.8-1.4) \\
1.0(0.8-1.2) \\
1.1(0.8-1.6)\end{array}$ \\
\hline & PUFA & $\begin{array}{l}\text { highest (>8.0 g/1000 } \\
\text { kcal) vs. lowest ( } \leq 5.5 \\
\mathrm{~g} / 1000 \mathrm{kcal}) \text { tertile }\end{array}$ & $\begin{array}{l}\text { mutated } K \text {-rasicontols } \\
\text { wild type } K \text {-ras/controls } \\
\text { mutated } K \text {-rasiwild type } K \text {-ras }\end{array}$ & $\begin{array}{l}1.1(0.8-1.4) \\
1.1(0.9-1.4) \\
1.0(0.7-1.4)\end{array}$ \\
\hline
\end{tabular}

\section{Cohort study}

\begin{tabular}{|c|c|c|}
\hline $\begin{array}{l}608 \text { incident } \\
\text { colon and rectal } \\
\text { cancer cases and } \\
2948 \text { subcohort } \\
\text { members } \\
\text { Brink et al, } 2004\end{array}$ & total fat & $\begin{array}{l}\text { highest ( } 109.1 \mathrm{~g} / \text { day) } \\
\text { vs. lowest }(78.1 \mathrm{~g} / \mathrm{day}) \\
\text { quartile for men, } \\
\text { highest ( } 85.3 \mathrm{~g} / \text { day) vs } \\
\text { lowest ( } 63.0 \mathrm{~g} / \text { day) } \\
\text { quartile for women }\end{array}$ \\
\hline
\end{tabular}

saturated fat highest ( $45.8 \mathrm{~g} /$ day) vs. lowest ( $28.9 \mathrm{~g} /$ day) quartile for men, highest ( $36.6 \mathrm{~g} /$ day) vs. lowest ( $23.9 \mathrm{~g} /$ day) quartile for women

MUFA

PUFA

linolenic acid

highest ( $42.5 \mathrm{~g} /$ day) vs. lowest ( $28.2 \mathrm{~g} /$ day) quartile for men, highest ( $33.0 \mathrm{~g} /$ day) vs. lowest (22.4 g/day) quartile for women

highest ( $29.1 \mathrm{~g} /$ day $)$ vs. lowest (11.6 g/day) quartile for men. highest ( $22.5 \mathrm{~g} /$ day) vs. lowest $(8.8 \mathrm{~g} /$ day) quartile for women

highest $(2.0 \mathrm{~g} /$ day $)$ vs. lowest ( $0.8 \mathrm{~g} /$ day) quartile for men, highest ( $1.6 \mathrm{~g} /$ day) vs. lowest $(0.6 \mathrm{~g} /$ day) quartile for women

linoleic acid highest $(27.9 \mathrm{~g} /$ day $)$ vs. lowest ( $10.0 \mathrm{~g} /$ day) quartile for men, highest (21.2 g/day) vs. lowest (7.4 g/day) quartile for women

\section{Colon}

wild type $K$-ras/subcohort mutated $K$-ras/subcohort

Rectum

wild type $K$-ras/subcohort mutated $K$-ras/subcohort

$0.99(0.70-1.38)$

$0.88(0.54-1.44)$

$0.63(0.33-1.20)$

$1.18(0.63-2.23)$

\section{Colon}

wild type $K$-ras/subcohort mutated K-ras/subcohort

Rectum

wild type $K$-ras/subcohort mutated $K$-ras/subcohort

$1.06(0.74-1.54)$

$0.73(0.45-1.18)$

$0.64(0.34-1.21)$

$0.86(0.43-1.72)$

\section{Colon}

wild type $K$-ras/subcohort mutated K-ras/subcohort

Rectum

wild type K-ras/subcohort mutated K-ras/subcohort

$1.18(0.60-1.26)$

$0.67(0.40-1.13)$

$0.69(0.38-1.24)$

$1.22(0.61-2.44)$

Colon

wild type $K$-ras/subcohort mutated K-ras/subcohort

$0.91(0.63-1.31)$ $2.09(1.25-3.49)$

Rectum

wild type $K$-ras/subcohort

$0.89(0.49-1.62)$ mutated K-ras/subcohort

$0.75(0.39-1.44)$

Colon

wild type $K$-ras/subcohort mutated K-ras/subcohort

$1.05(0.74-1.49)$

$0.95(0.59-1.55)$

Rectum

wild type $K$-ras/subcohort

$0.66(0.37-1.17)$ mutated $K$-ras/subcohort

$1.54(0.73-3.25)$

Colon

wild type $K$-ras/subcohort

$1.01(0.70-1.45)$ mutated K-ras/subcohort

$2.19(1.30-3.67)$

Rectum

wild type $K$-ras/subcohort

$1.12(0.61-2.07)$

$0.93(0.48-1.79)$

$R R$ only in study by Brink ef $a l$, in all other studies the $O R$ is used 
evaluate the influence of selection and information bias on misclassification. In addition, implications of possible measurement errors in the assessments of dietary factors and $K$-ras mutations, followed by confounding and multiple testing will be discussed.

\section{Selection bias}

Since the person-year follow-up was nearly $100 \%$ complete $(98 \%$ for 7.3 years of follow-up), selection bias in general is unlikely to be important in The Netherlands Cohort Study on diet and cancer (NLCS). The cohort was recruited from samples drawn from a large number of municipal population registries. Municipalities were selected according to the degree of coverage of their inhabitants by the cancer registries (CR) and PALGA, minimising loss to follow-up (7). The mean coverage appeared to increase from $98.5 \%$ at the start of the study to $100 \%$ in 1988 . Therefore, tumour tissue of CRC patients was

Table 3 Main findings of the molecular epidemiological studies on the associations between dietary folate intake and $K$-ras mutations in sporadic CRC

\begin{tabular}{|c|c|c|c|c|}
\hline $\begin{array}{l}\text { Study } \\
\text { population }\end{array}$ & Dietary factor & Contrast & Comparison & OR or RR* $(95 \% \mathrm{Cl})$ \\
\hline \multicolumn{5}{|c|}{ Cross-sectional study } \\
\hline \multirow{3}{*}{$\begin{array}{l}678 \text { colorectal } \\
\text { adenoma } \\
\text { cases } \\
\text { Marinez et al, } \\
1999 \text { (1) }\end{array}$} & dietary folate & $\begin{array}{l}\text { highest ( }>318 \mu g / \text { day) } \\
\text { vs. lowest }(<226 \mu g \text { ) } \\
\text { day) tertile }\end{array}$ & mutated $K$-ras/wild type $K$-ras & $0.91(0.50-1.64)$ \\
\hline & $\begin{array}{l}\text { dietary + supple- } \\
\text { mental folate }\end{array}$ & $\begin{array}{l}\text { highest ( }>571 \mu g / \text { day) } \\
\text { vs. lowest }(<279 \mu g / \text { ) } \\
\text { day) tertile }\end{array}$ & mutated $K$-ras/wild type $K$-ras & $0.52(0.30-0.88)$ \\
\hline & \multicolumn{3}{|c|}{ Case-control study } & \\
\hline
\end{tabular}

108 colorectal folic acid cancer cases highest vs. lowest tertile mutated $K$-ras/wild type $K$-ras

$2.03(0.68-6.11)$

and 295

controls

Bautista et al,

1997 (5)

$\begin{array}{lllll}1428 \text { colon } & \text { folate } & \text { lowest }(\leq 125 \mathrm{mcg} & \text { mutated } K \text {-ras/controls } & 1.2(0.8-1.7)^{* *} \\ \text { cancer cases } & & / 1000 \mathrm{kcal}) \text { vs. highest } & \text { wild type } K \text {-ras/controls } & 1.4(1.1-1.8)^{* *} \\ \text { and 2406 } & (>220 \mathrm{mcg} / 1000 \mathrm{kcal}) & \text { mutated K-ras/wild type } K \text {-ras } & 0.8(0.6-1.2)^{* *} \\ \text { controls } & \text { tertile** } & 2 \text { G>Alwild type } K \text {-ras } & 0.7(0.4-1.3)^{* *}\end{array}$

Slattery et al,

$2000(4)$

\section{Cohort study}

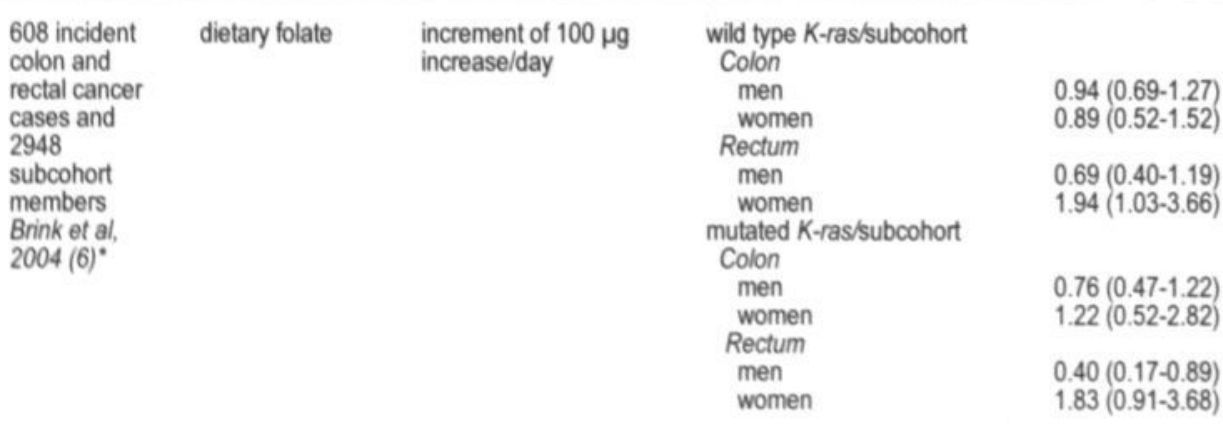

\footnotetext{
'RR only in study by Brink ef al, in all other studies the OR is used

"the reference category is the highest level of intake of folate (instead of the lowest level of intake, as in the other studies in the tabel
} 
collected for the patients identified between 2.3 and 7.3 years after the start of the NLCS (in 1986), i.e. patients diagnosed with CRC between 1989 and 1994.

Within this 5-year period, 929 incident CRC cases with histologically confirmed tumours were identified of whom 819 cases could also be linked to a PALGA report of the lesion. The linkage to the PALGA database, and thus to the availability of the individual pathological reports, was necessary in order to locate the tumour material at a specific laboratory. Reasons for not finding PALGA reports for $12 \%$ of the eligible patients include: 1) PALGA alone reached national coverage from 1991 onwards, although the NCR and PALGA combined reached a coverage of near $100 \%$ in the municipalities included in our study by $1988,2)$ approximately $6 \%$ of histologically confirmed cases in the NCR are not reported by PALGA due to administrative reasons (data Comprehensive Cancer Center Limburg 19901996, personal communication L. Schouten) and 3) mistakes in identifying information, leading to incorrect linkage, i.e. name, date of birth and gender. The pathology laboratories that did, or did not deliver their reports to PALGA after 1991 were not different with respect to location in an academic hospital or a cancer specialty centre. Therefore, it is not expected that differential selection bias occurred with respect to dietary intake or tumour characteristics.

In this study, tissue blocks were available for $83 \%$ of the cases (776 out of 929) since the PALGA report of the lesion was unavailable for $12 \%$ of cases (110 out of 929 resulting in 819 ) and an additional $5 \%$ ( 43 out of 819 , i.e. 776 ) of the tumour blocks could not be traced. Reasons for this loss to follow-up of tumour blocks $(\mathrm{N}=43)$ were 1) for 9 patients registered in one pathology laboratory, tissue could not be retrieved due to administrative inconsistencies and 2) for 34 patients the material could not be found (8). In addition, for $5 \%$ of the patients (i.e. 39 out of 776) the K-ras mutation status could not be determined due to either the presence of only normal colon mucosa (20 out of 39), a revision with a benign adenoma instead of an adenocarcinoma (10 out of 39), an insufficient yield of DNA (6 out of 39) or the absence of malignant CRC tissue (3 out of 39) (6).

Nearly all tumour material of CRC patients was collected from the various pathology laboratories by one person, usually by retrieval directly from the archives on location instead of requesting the material by mail. This approach could have increased the invaluable willingness of the pathologists to cooperate in the current study, since this way of collecting the tumour material was both time and cost efficient for the pathology departments. Both the degree of participation and the yield of the samples are not expected to be related to either characteristics of the tumour or dietary intake.

Taken together, the recovery of the tumour tissue is considered as more than satisfactory, and it is not anticipated that selection bias would lead to differential misclassification of the $K$-ras mutation status of the tumour. The series of samples that were analysed consist of non-selected, incident CRC patients, representative for the NLCS.

\section{Information bias}

It is unlikely that systematic misclassification of exposure is of significant importance in the current study, since all prevalent cases (i.e. clinically diagnosed) were excluded at baseline. All other participants completed a validated, semi-quantitative food frequency questionnaire at baseline. In addition, due to the exclusion of the first 2.3 years of follow-up. influence of pre-clinical CRC on dietary intake was minimised.

\section{Assessment of dietary factors}

The intake data were validated against a nine-day record method (9). The observed correlations were reasonable and were not different from the correlations observed in other studies (chapters 3 through 5). Even though estimations of intake may not be as accurate as we would wish them to be, possible misclassification is expected to be non-differential with 
respect to K-ras mutation status. Therefore, the associations observed are probably an underestimation of the true association.

\section{Assessment of $\mathrm{K}$-ras mutations}

Mutation analysis of tumour samples, in particular when routinely-fixed, paraffinembedded tissue is used obtained within a multi-centred setting, is prone to false positive as well as false negative results. The sensitivity and specificity of the methods used for $K$-ras mutations in the current study are discussed in detail in chapter 2 . Findings regarding the reproducibility and validity of these techniques will be discussed briefly in this paragraph.

\section{Reproducibility}

To establish the reproducibility of the technique in our study, a subset of DNA specimens was subjected twice to the complete procedure, from tissue sectioning to DNA sequencing (chapter 2). The reproducibility of the mutation analysis was found to be good $(88 \%)$, in view of the poor DNA template quality of a significant proportion of the archival tissue samples. Surprisingly little has been published on reproducibility of $K$-ras mutation identification in the other reported molecular epidemiological studies (1-5). In our study, the reproducibility appeared to be strongly dependent on the quality of the DNA after tissue processing. The degree of fragmentation of the DNA templates, mainly due to effects of tissue lysis and formalin fixation, is critical for amplification of the K-ras fragments, in particular in the first cycles of the PCR. The reproducibility is also dependent on the heterogeneity of the tumour tissue, i.e. on the presence of a variety of clones with different genetic make-up in the tumour. However, the effect of tissue heterogeneity has not been tested experimentally.

In the current study, routinely-fixed, paraffin-embedded colorectal tumour specimens from 54 pathology departments were used for the determination of the K-ras mutation status. Variation in procedures for post-operative storage, fixation, dehydration and paraffinembedding of the tissue between tumour samples as well as between pathology laboratories affect the degree of DNA fragmentation and hence the quality of the DNA to be analysed. Therefore, we took several precautions to warrant a reliable mutation analysis. The exon 1 fragment of the K-ras gene, including codons 12 and 13 , is a small fragment (114 bp) that can be amplified easily and reliably. Only purified, complete fragments were used for sequencing, the accepted standard for determination of the $K$-ras mutation status. In the end, the K-ras mutation status could be determined for all 737 colorectal tumour specimens included in this study, the reproducibility is $88 \%$, and the frequency of the $K$-ras mutations is in line with the frequencies observed in the literature.

\section{Validity}

Several experiments were conducted to validate the assessment of the $K$-ras mutation status of the archival samples (chapter 2). The mutation analysis was validated by amplification and sequencing DNA fragments from CRC cell lines, and from adjacent blocks with paraffin-embedded and fresh tissue from a series of CRC specimens. The validation of the used techniques indicated that the observed point mutations of the CRC cell lines are the same as those reported in the literature. Tissue processing under controlled conditions was found not to affect the reliability of our $K$-ras mutation analysis of archival specimens. Therefore, errors in the assessment of $K$-ras mutations may occur at low frequency, mainly due to an intrinsic, poor quality of DNA from samples.

Most importantly, differential misclassification of the $K$-ras mutation status of tumours is not very plausible, since molecular analysis and evaluation of data was done blinded with respect to dietary intake, potential confounders or tumour characteristics such as clinicopathological data of tumours. In addition, evaluation of sequence patterns and data 
entry were done by two different laboratory technicians, results were compared, and in case of dissimilarities, data were reviewed together until consensus was obtained.

In conclusion, potential misclassification of cases regarding the $K$-ras mutation status of their tumour, due to minor faults in the reproducibility and validity of the used techniques, is expected to be non-differential with respect to other aspects of the tumour as well as dietary intake.

\section{Confounding}

Meat consumption, fat intake and dietary folate were evaluated for their relation with overall colon and rectal cancer and with the $K$-ras mutation status in chapters 3,4 and 5 , respectively. The influence of possible confounders, based on the literature, was tested in the overall colon and rectal cancer models, i.e. without stratification on presence or absence of a $\mathrm{K}$-ras mutation. Hence, the variables, significant in either one or both of the models, were included as covariates for all models to be tested, i.e. models for specific molecular endpoints as determined by the $K$-ras mutation status. Possibly, confounders included in the overall models are not important confounders for the associations studied with the $K$-ras mutation status in colon or rectal cancer. In addition, unknown confounders specific to the diet-K-ras mutation status associations studied may have played a role. However, we would rather not explore all potential confounders for the associations studied in our dataset because of the increased chance of type-I errors. Since little is known about potential confounders, we restricted our evaluations to the known confounders for the specific dietCRC associations.

\section{Multiple testing}

In total, sixteen food groups or nutrients were considered in this thesis. As differences in the aetiology of colon and rectal cancer have been reported (10), statistical data-analyses were performed separately for colon and rectal cancer as described in chapters 3, 4 and 5 . In addition, results were presented separately for men and women in chapter 5 . Including the K-ras mutation status of the tumours, 170 Cox proportional Hazard tests were performed. A p-value $\leq 0.05$ was considered statistically significant. In general, $5 \%$ of these tests ( 9 out of 170 tests) may be found statistically significant, based on chance alone. We observed 18 statistically significant associations. Therefore, caution is warranted in interpreting our results. However, the choice of associations we investigated was primarily based on prior hypotheses, generally generated from experimental studies.

\section{IMPLICATIONS OF THE FINDINGS OF THIS STUDY AND FUTURE PERSPECTIVES}

The relevance of the diet-gene associations with respect to the different aetiology of colon and rectal cancer, the importance to the specific molecular alterations in the $\mathrm{K}$-ras gene versus the wild type gene, and other relevant mechanisms for the risk of CRC, will be discussed.

\section{Differences in aetiology between colon and rectal cancer}

Many of the associations observed in this study were either confined to cancer in the colon or cancer in the rectum, rarely both. Considering our hypotheses set out in chapter 1 , these differences were unexpected. However, in view of the finding that the K-ras mutation status of tumours differed along the colorectal tract (chapter 2), and suggestions in literature for differences in the aetiology of tumours in the colon versus the rectum $(10,11)$, differences according to localization in the colorectal tract are not surprising, after all. Nevertheless, the differences in associations of dietary factors with colon and rectal cancer with or without 
mutations in the $K$-ras gene cannot readily be explained with underlying biological mechanisms that are known at present. Therefore, stratified analyses at different sites in the colorectal tract are preferable if allowed by the power of the study. In our study, patients with a rectosigmoid tumour $(n=85)$ were excluded, since the tumours in this rather more clinically than anatomically defined region could not be assigned to either the colon or the rectum. Moreover, the number of patients with rectosigmoid tumours is too small for adequate stratified analyses regarding the $K$-ras mutations status. Finally, replication of our findings with regard to the $K$-ras gene for both colon and rectal cancer would be reassuring.

\section{The importance of point mutations in the $\boldsymbol{K}$-ras gene versus wild type $\boldsymbol{K}$-ras gene}

Overall, some hypotheses suggested in chapter 1 were confirmed, some were not and, surprisingly, some associations were observed for the wild type $K$-ras gene for which there were no prior hypotheses.

In chapter 3, it was suggested that meat preparation is relevant for development of CRC, i.e. broiled, fried, barbequed or smoked meats may increase the risk through the generation of high concentrations of carcinogens, like PAA's and PAH's. Subsequently, these carcinogens may induce specific point mutations. Information on meat preparation was not collected at baseline in the current study. Since fresh meat generally needs further preparation, this type of meat may be an important source of these carcinogens. Hence, it is plausible that associations between fresh meat and colon or rectal cancer with specific point mutations in the $\mathrm{K}$-ras gene exist. However, in this study no association was found between any of the fresh meat variables and risk of colon or rectal cancer with specific point mutations (chapter 3). This could be due to the expected low content of carcinogens in prepared fresh meat consumed in this cohort, and also to the lack of correlation between meat preparation and the amount of fresh meat consumed (12). Surprisingly, associations were observed between certain fresh meat variables and cancer with a wild type $K$-ras gene (chapter 3), i.e. a positive association between colon cancer risk and beef consumption and inverse associations between both colon and rectal cancer risk and pork consumption. Associations with the risk of colon tumours harbouring a wild type $K$-ras gene were also observed with meat products consumption. Although associations were weak and of opposite direction for different meat variables, and may be the result of type I errors, these associations are intriguing and require replication and further study. More specifically, it is of interest to focus on the $K$-ras independent pathway in relation to meat consumption in future studies. For rectal tumours, our observations regarding the increased risk of tumours harbouring $\mathrm{G}>\mathrm{A}$ transitions support our initial hypothesis regarding the consumption of meat products (chapter 3). However, the lack of this association for colon cancer remains puzzling.

Regarding fat intake, an increased association was observed between PUFA, in particular linoleic acid, and $\mathrm{G}>\mathrm{A}$ transitions and $\mathrm{G}>\mathrm{T}$ or $\mathrm{G}>\mathrm{C}$ transversions in the K-ras gene of colon cancer patients (chapter 4). These findings are in line with the observations in previous experimental studies, but need replication in other observational epidemiological studies. On the other hand, the hypotheses regarding MUFA and $\omega-3$ PUFA and K-ras mutation status in CRC were not confirmed in the current study. One possible explanation is that the intake of MUFA and $\omega-3$ PUFA in The Netherlands is too low to evoke its potentially protective effect. Another explanation could be that MUFA and $\omega-3$ PUFA are not involved in the development of CRC via a K-ras-dependent pathway. Indeed, for MUFA intake, Bautista observed a significant inverse association with the risk of CRC with a wild type $K$-ras gene (5) in a case-control study in Spain where the intake of MUFA is higher than in The Netherlands. This underlines, once again, the potential importance the K-ras independent route to colorectal carcinogenesis in relation to dietary intake. The uncertain role of MUFA 
and $\omega-3$ PUFA in colorectal carcinogenesis with respect to the $K$-ras gene needs further study.

An inverse association was observed for dietary folate and the risk of rectal tumours with a mutated $K$-ras gene in men, irrespective of the type of point mutation involved (chapter 5). For women, however, a positive association was observed with the risk of rectal tumours harbouring a wild type $K$-ras gene or a $K$-ras mutation. Moreover, the increased association with $K$-ras mutations was confined to $\mathrm{G}>\mathrm{T}$ or $\mathrm{G}>\mathrm{C}$ transversions. An inverse association was also seen with rectal tumours harbouring a $\mathrm{G}>\mathrm{A}$ transition and this finding is in line with the hypothesis. Possibly, the effect of dietary folate is differential for men and women. However, these findings also need replication in other prospective cohort studies.

Overall, our results suggest that meat, fat and folate appear to be of less importance for the risk of colon and rectal tumours with specific point mutations in the $K$-ras gene than was attributed to these factors at the start of the study. However, these factors may be of aetiologic importance for the risk of colon or rectal tumours with a wild type K-ras gene. Several literature reports never focussed on the findings observed with wild type $K$-ras tumours, partly because a definite conclusion on the risk of wild type $K$-ras tumours alone was hampered by the case-case approach only $(1,2)$. On the other hand, both Bautista and Slattery observed significant associations between dietary factors, i.e. MUFA (5), folate (4) and cruciferous vegetables (4) and the risk of tumours with the wild type $K$-ras gene. It would therefore be useful to study associations between dietary factors and the risk of colon and rectal tumours with molecular characteristics compatible with wild type $K$-ras, such as microsatellite instability of the tumour.

\section{Importance of mechanisms other than the mutation status of the $\boldsymbol{K}$-ras gene}

Although we focused on hypotheses related to specific point mutations in the $K$-ras gene, it is interesting to consider other mechanisms relevant for the risk of CRC.

\section{Other (epi)genetic mechanisms}

As indicated above, other genes relevant for colorectal carcinogenesis $(13,14)$ should also be studied in this respect. The most important genes include the tumour suppressor gene $A P C$, the oncogene $\beta$-catenin and the DNA repair enzymes (see fig 1 in chapter 1). The focus should not only be on specific point mutations in these genes but could also be on epigenetic aspects such as promotor methylation of the APC gene. Methylation of the promotor region of genes is important for the expression of genes, and therefore for normal functioning of gene products $(15,16)$. A number of dietary factors are thought to influence methylation (16). Therefore, (epi)genetic factors involved in colorectal carcinogenesis may be of importance, to be investigated in relation to dietary factors, in addition to the $K$-ras gene alone.

Another aspect to be explored in the future may be the association between dietary factors and types of mutations, not with respect to a specific gene, but genome-wide. When regarding the underlying biological mechanisms for associations between dietary factors and specific point mutations, an association between for example the consumption of PUFA and the increased risk of $\mathrm{G}>\mathrm{A}$ transitions occurring throughout the genome in tumour cells from CRC patients may be plausible. However, caution is warranted, as the assessment of e.g. G>A transitions will be performed in colorectal tumour tissue from patients already diagnosed with the cancer. Therefore, the assessment of $G>A$ transitions will reflect the genetic make-up of the tumour at the time of diagnosis and is the result of the effects of many different factors responsible for the selective growth advantage of the tumour, and not only dietary factors. This also applies to the findings in this thesis, since the mutation status of the $\mathrm{K}$-ras gene is also the status of the tumour cells at the time of diagnosis. 


\section{Dietary factors as indirect cancer promoting effectors}

Dietary factors may act as promotor-stimulating compounds in the development of CRC instead of as initiating factors by causing specific point mutations. Cells may become more or less susceptible to cell division, depending on dietary intake as well as on the molecular make-up of the cells, for example, the $K$-ras mutation status of the cell. As a result, associations between dietary factors and colon or rectal tumours with a mutated $K$-ras gene may be observed. Whether this may be an explanation for our findings is not clear and needs further exploration in laboratory experiments.

Finally, it would be interesting to consider the role of polymorphisms in metabolic enzymes as effect-modifiers in the relationship between dietary factors and $K$-ras mutation status in CRC patients. Examples of polymorfic enzymes proposed to be involved in colorectal carcinogenesis are the NAT genes (17), involved in meat metabolism, the COX-2 gene (18), involved in fat metabolism, and the polymorphic genes involved in methyl metabolism (19), and thus potentially important to consider when studying the effects of folate.

\section{CONCLUSION}

Overall, our results suggest that meat, fat and folate appear to be of less importance for the risk of colon and rectal tumours with specific point mutations in the $K$-ras gene than was attributed to the factors at the start of the study, on the basis of biological mechanisms. However, these factors may be of aetiological importance for the risk of colon or rectal tumours with a wild type $K$-ras gene, strongly suggesting the effects of dietary factors on other pathways leading to CRC. This study shows that incorporating molecular endpoints in classical epidemiological studies of diet and cancer is a relevant approach to unravel the aetiology of colon and rectal cancer.

\section{REFERENCES}

1. Martinez ME, Maltzman T, Marshall JR, et al. (1999) Risk factors for Ki-ras protooncogene mutation in sporadic colorectal adenomas. Cancer Res, 59(20), 5181-5.

2. O'Brien H, Matthew JA, Gee JM, et al. (2000) K-ras mutations, rectal crypt cells proliferation, and meat consumption in patients with left-sided colorectal carcinoma. Eur $J$ Cancer Prev, 9(1), 41-7.

3. Kampman E, Voskuil DW, van Kraats AA, et al. (2000) Animal products and K-ras codon 12 and 13 mutations in colon carcinomas. Carcinogenesis, 21(2), 307-9.

4. Slattery ML, Curtin K, Anderson K, et al. (2000) Associations between dietary intake and $\mathrm{Ki}$-ras mutations in colon tumors: a population-based study. Cancer Res, 60(24), 6935-41.

5. Bautista D, Obrador A, Moreno V, et al. (1997) Ki-ras mutation modifies the protective effect of dietary monounsaturated fat and calcium on sporadic colorectal cancer. Cancer Epidemiol Biomarkers Prev, 6(1), 57-61.

6. Brink M, Weijenberg MP, de Goeij AF, Schouten LJ, Koedijk FD, Roemen GM, Lentjes $\mathrm{MH}$, de Bruïne AP, Goldbohm RA and van den Brandt PA. (2004) Fat and K-ras mutations in sporadic colorectal cancer in The Netherlands Cohort Study. Carcinogenesis, 25(9), 1619-1628.

7. van den Brandt PA, Schouten LJ, Goldbohm RA, Dorant E, Hunen PM. (1990) Development of a record linkage protocol for use in the Dutch Cancer Registry for Epidemiological Research. Int J Epidemiol, 19(3), 553-8. 
8. Brink M, De Goeij AF, Weijenberg MP, Roemen GM, Lentjes MH, Pachen MM, Smits KM, de Bruilne AP, Goldbohm RA and van den Brandt PA. (2003) K-ras oncogene mutations in sporadic colorectal cancer in The Netherlands Cohort Study. Carcinogenesis, 24(4), 703-710.

9. Goldbohm RA, van den Brandt PA, Brants HA, et al. (1994) Validation of a dietary questionnaire used in a large-scale prospective cohort study on diet and cancer. Eur $J$ Clin Nutr, 48(4), 253-65.

10. Wei EK, Giovannucci E, Wu K, et al. (2004) Comparison of risk factors for colon and rectal cancer. Int.J.Cancer, 108, 433-442.

11. Potter JD, McMichael AJ. (1986) Diet and cancer of the colon and rectum: a casecontrol study. J Natl Cancer Inst, 76(4), 557-69.

12. Bausch-Goldbohm RA, Voorrips L, Bos G, van den Brandt PA. (2000) Vlees en dikkedarm kanker. TNO rapport, 1-32.

13. Fearon ER, Vogelstein B. (1990) A genetic model for colorectal tumorigenesis. Cell, 61(5), 759-67.

14. Sparks AB, Morin PJ, Vogelstein B, Kinzler KW. (1998) Mutational analysis of the APC/beta-catenin/T cf pathway in colorectal cancer. Cancer Res, 58(6), 1130-4.

15. Esteller M, Toyota M, Sanchez-Cespedes M, et al. (2000) Inactivation of the DNA repair gene O6-methylguanine-DNA methyltransferase by promoter hypermethylation is associated with $\mathrm{G}$ to $\mathrm{A}$ mutations in K-ras in colorectal tumorigenesis. Cancer Res, 60(9), 2368-71.

16. van Engeland M, Weijenberg MP, Roemen GM, et al. (2003) Effects of dietary folate and alcohol intake on promoter methylation in sporadic colorectal cancer: the Netherlands cohort study on diet and cancer. Cancer Res, 63(12), 3133-7.

17. Brockton N, Little J, Sharp L, Cotton SC. (2000) N-acetyltransferase polymorphisms and colorectal cancer: a HuGE review. Am J Epidemiol, 151(9), 846-61.

18. Bruce WR, Giacca A, Medline A. (2000) Possible mechanisms relating diet and risk of colon cancer. Cancer Epidemiol Biomarkers Prev, 9(12), 1271-9.

19. Choi SW, Mason JB. (2002) Folate status: effects on pathways of colorectal carcinogenesis. J Nutr, 132(8 Suppl), 2413S-2418S. 
Summary 
Current epidemiological evidence for associations between dietary factors with overall colorectal cancer (CRC) risk is weak or inconsistent. This could be due to methodological factors such as study design, selection bias and information bias. It could also be due to the heterogeneity of the cancer endpoint that is studied. Subtypes of colorectal cancer patients could be distinguished by the absence or presence of alterations in genes involved in the development of colorectal cancer. Therefore, more insight in the aetiology of colorectal cancer can be obtained by studying the associations between dietary factors and alterations in genes involved in the early development of cancer. The majority $(95 \%)$ of colorectal cancer is non-hereditary, i.e sporadic, and develops from small adenomatous polyps through a well-defined sequence of cytological changes and this development is associated with the accumulation of alterations in tumour suppressor genes and oncogenes regulating cell division and growth. Among the early alterations that occur in $40 \%$ of the colorectal carcinomas are somatic mutations in the $K$-ras oncogene. Approximately $90 \%$ of the activating mutations in this gene is found in codons 12 and 13 of exon 1 and around $5 \%$ in codon 61 located in exon 2. The most prevalent point mutations in exon 1 are the G>A transitions, the $\mathrm{G}>\mathrm{T}$ transversions and the $\mathrm{G}>\mathrm{C}$ transversions. The aim of this molecular epidemiological study was to obtain more insight in the associations between dietary factors and the risk of colorectal tumours with or without specific point mutations in exon 1 of the $K$-ras oncogene.

The studies described in this thesis are embedded in The Netherlands Cohort Study on diet and cancer (NLCS). The NLCS was initiated in 1986 and includes 58,279 men and 62,573 women (55-69 years of age) who originated from 204 Dutch municipalities with computerized population registries and who completed a self-administered questionnaire on diet, family history of cancer and other risk factors for cancer. The entire cohort is monitored for cancer occurrence by annual linkage to The Netherlands Cancer Registry (NCR) and to PALGA, a nationwide network and registry of histo- and cytopathology. Accumulation of person-time in the cohort has been estimated through biennial vital status follow-up of a subcohort of 3,500 men and women who were randomly selected after baseline exposure measurement. After 7.3 years of follow-up and with the exclusion of the first 2.3 years, 929 incident cases with histologically confirmed CRC were observed of whom 819 could also be linked to a PALGA report of the lesion. The tumour tissue samples of these 819 cases were distributed over 54 pathology laboratories throughout The Netherlands. After approval of the Medical Ethical committees, PALGA, the pathologists and the NCR the tissue blocks were made available for this study. Of the 819 tumour tissue samples that were identified, 775 $(95 \%)$ could be traced and for 737 of these ( $95 \%$ of the available blocks), the $K$-ras mutation status of exon 1 (including exons 12 and 13) could be determined.

In chapter 1 an overview is presented of the associations between dietary factors and colorectal cancer, and of the (genetic) development of colorectal cancer with special attention for the $K$-ras oncogene. Although much research is performed on diet and colorectal cancer so far, there are still only few studies available on the associations between dietary factors and $K$-ras oncogene mutations in colorectal cancer.

The frequency of $K$-ras oncogene mutations in tumours of incident colorectal cancer patients from the NLCS is described in chapter 2. Moreover, the method of mutation detection used in the current study, i.e. direct sequencing of amplified and purified $K$-ras gene fragments, was validated by the confirmation of reported $K$-ras mutation status in CRC cell lines and by a good correlation between fresh-frozen and routinely-fixed, paraffinembedded tissue The detection limit of mutated DNA was $5 \%$. The reported frequency of $K$ ras mutations was observed to be $37 \%$ among 737 incident colorectal cancer patients, with codons 12 and 13 as the most frequently affected codons (94\%). The G>A transition and the $\mathrm{G}>\mathrm{T}$ and $\mathrm{G}>\mathrm{C}$ transversions were the most frequently observed point mutations, with the $\mathrm{G}>\mathrm{T}$ transversion primarily confined to codon 12 . Rectal tumours were found to have the 
highest frequency of $\mathrm{G}>\mathrm{T}$ transversions, as compared to colon or rectosigmoid tumours. Stratification by gender revealed that this difference was confined to the female patients. No significant differences between tumours with or without specific $K$-ras mutations were observed for Dukes' stage or tumour differentiation grade.

Subsequently, associations between several dietary factors and the risk of colon or rectal tumours with or without $K$-ras gene mutations were studied. The choice of dietary factors evaluated in the current thesis was based on biological mechanisms underlying the development of specific $K$-ras mutations in colorectal cancer. Differences in the $K$-ras mutation pattern at various subsites in the colorectal tract and in the aetiology of colon and rectal cancer have been reported, and therefore, summarised results from the NLCS are presented separately for colon and rectal cancer (chapters 3 through 5). Patients with a rectosigmoid tumour $(n=85)$ were excluded due to the criterion for classifying rectosigmoid tumours and due to the small number of patients for adequate stratified analyses regarding the $K$-ras mutation status.

It was hypothesized that high levels of heterocyclic aromatic amines (HAA), generated by high temperature cooking of meat proteins, and polycyclic aromatic amines (PAH) originating from grilling and smoking of meat contribute to the occurrence of $K$-ras point mutations. In chapter 3, associations between the intake of (several types of) meat, meat products and fish, and the risk of colon or rectal tumours with or without a $K$-ras mutation. Significant associations were mainly observed between meat and meat products and tumours with a wild type $K$-ras gene. A high consumption of beef and meat products was associated with an increased risk of wild type $K$-ras tumours in the colon, but not in the rectum. A high consumption of pork was inversely related with wild type $K$-ras tumours in both colon and rectum. Based on these results, it was concluded that high consumption of (several types of) meat and meat products may be relevant for the aetiology of colon and rectal cancer.

Based on experimental results, it was hypothesized that $\omega-6$ polyunsaturated fat (PUFA) peroxidation leads to the formation and accumulation of malondialdehyde and 4hydroxynonenal. These by-products could form DNA-adducts with guanine bases which finally may result in $G>A$ transitions or $G>T$ transversions. Is a high $\omega-6$ PUFA intake associated with an increased risk of $G>A$ transitions or $G>T$ transversions in the $K$-ras gene of colon and rectal cancer patients? This was the aim of chapter 4 . Null findings were observed for the intakes of total fat, saturated fat, monounsaturated fat and $\omega-3$ PUFA, and colon and rectal cancer, overall and also after the $K$-ras mutation status was taken into account. Intake of dietary PUFA (total intake of $\omega-3$ and $\omega-6$ fatty acids) and specifically linoleic acid (as the main source of $\omega-6$ fatty acids) was associated with an increased risk of mutated $K$-ras colon tumours. Similar associations were observed for the specific $K$-ras point mutations, i.e. the $\mathrm{G}>\mathrm{A}$ transitions, $\mathrm{G}>\mathrm{T}$ and $\mathrm{G}>\mathrm{C}$ transversions, in colon tumours. For rectal cancer, however, no associations were observed with overall risk or with $K$-ras mutation status. Possibly, intake of PUFA, especially the $\omega-6$ PUFA, is associated with an increased risk of colon tumours with a $K$-ras gene mutation.

Folate plays an important role in one-carbon metabolism, in DNA synthesis and in methylation of DNA and proteins. Deficient folate intake may generate genomic instability through reduced availability of thymine for DNA synthesis and through increased incorporation of uracil, which may lead to more DNA strand breaks. In addition, global genome hypomethylation and regional hypermethylation in gene promoters could occur as another result of deficient folate intake. In chapter $\mathbf{5}$ the relation between folate and $K$-ras mutation status in colon or rectal cancer patients was studied. For men, folate appears to be inversely associated with the overall risk of rectal cancer, and this association was confined to mutated $K$-ras tumours. For women, however, an increased association was observed between high folate intake and the risk of overall rectal cancer. With respect to the $K$-ras 
mutation status, the increased association remained for both wild type and mutated $K$-ras tumours. Moreover, this increased association was confined to rectal tumours harbouring $\mathrm{G}>\mathrm{T}$ and $\mathrm{G}>\mathrm{C}$ transversions, whereas a significant inverse association was observed with rectal tumours harbouring a $\mathrm{G}>\mathrm{A}$ transition. Folate seems to play a role in the aetiology of rectal cancer through the involvement of the $K$-ras oncogenes. Results from this study indicate that future molecular epidemiological research on folate intake need to account for sex differences.

In chapter 6, the most important findings of our study are summarized and compared with the findings of other relevant molecular epidemiological studies. Overall, our results suggest that meat, fat and folate appear to be of less importance for the risk of colon and rectal tumours with specific point mutations in the $K$-ras gene than was attributed to these factors at the start of the study. However, these factors may be of aetiological importance for the risk of colon or rectal tumours with a wild type $K$-ras gene. In addition, the possibilities and pitfalls of molecular epidemiological studies are discussed in this chapter. Moreover, other genetic factors are pointed out which can be studied in future molecular epidemiological research. This study shows that incorporating molecular endpoints in classical epidemiological studies of diet and cancer is a relevant approach the aetiology of colon and rectal cancer. 
Samenvatting 
Epidemiologische studies hebben tot nu toe zwakke of tegenstrijdige relaties laten zien tussen voedingsfactoren en het risico op kanker van de dikke darm (colorectum: colon, rectosigmoïd en rectum). Dit kan te maken hebben met methodologische factoren zoals de onderzoeksopzet, selectiebias en informatiebias. Een andere verklaring kan zijn dat dikke darmkanker te heterogeen is om beschouwd te kunnen worden als één ziektebeeld. Mogelijk zijn er meerdere subgroepen van patiënten te onderscheiden door ze in te delen op basis van de af- of aanwezigheid van afwijkingen in genen die betrokken zijn bij de ontwikkeling van dikke darmkanker. Meer inzicht in het ontstaan van dikke darmkanker kan worden verkregen door de relaties te onderzoeken tussen voedingsfactoren en afwijkingen in genen die betrokken zijn bij de vroege ontwikkeling van kanker. Het merendeel (ongeveer $95 \%$ ) van dikke darmkanker behoort tot de sporadische vorm, dat wil zeggen dat ze niet zijn ontstaan uit erfelijke genetische afwijkingen. Volgens het gangbare model voor de ontwikkeling van dikke darmkanker ontstaan de meeste tumoren uit adenomateuze poliepen in een stapsgewijs proces. Tijdens dit proces stapelen afwijkingen zich op in tumorsuppressor-genen en oncogenen die de groei en differentiatie van dikke darmcellen reguleren. Somatische mutaties in het $K$-ras gen behoren tot de vroege veranderingen die plaatsvinden in een aanzienlijk deel $(40 \%)$ van tumoren in de dikke darm. De meeste mutaties in dit gen $(90 \%)$ worden gevonden in codons 12 en 13 van exon 1 en een klein deel $(5 \%)$ wordt gevonden in codon 61 in exon 2. De puntmutaties in exon 1 zijn vooral G>A transities, $G>T$ transversies en $\mathrm{G}>\mathrm{C}$ transversies. Het doel van dit moleculairepidemiologisch onderzoek was om meer inzicht te krijgen in de relatie tussen verschillende voedingsfactoren en het risico op dikke darmkanker waarbij onderscheid is gemaakt tussen tumoren met en tumoren zonder specifieke mutaties in exon 1 van het $K$-ras gen.

De studies die in dit proefschrift beschreven staan, zijn uitgevoerd binnen het kader van de Nederlandse Cohort Studie naar voeding en kanker (NLCS). De NLCS is gestart in 1986 met ruim 120.000 mannen en vrouwen (55-69 jaar) in 204 Nederlandse gemeenten met een geautomatiseerd bevolkingsregister, verspreid over het land. Bij de aanvang hebben de deelnemers een lijst met vragen over voedingsgewoonten, kanker in de familie en andere risicofactoren voor kanker ingevuld. Vervolgens is het optreden van kanker bij de deelnemers nagegaan door middel van jaarlijkse koppelingen met de Nederlandse Kanker Registratie (NKR) en met het Pathologisch Anatomisch Landelijk Geautomatiseerd Archief (PALGA). Tevens is bij aanvang van de NLCS een aselect subcohort gekozen, bestaande uit 3500 mannen en vrouwen, waarmee de persoonstijd voor het totale cohort wordt geschat. $\mathrm{Na} 7,3$ jaar follow-up, met uitzondering van de eerste 2,3 jaar, werden 929 patiënten met dikke darmkanker geïdentificeerd met behulp van koppeling met de NKR. Voor 819 van de 929 patiënten was ook een PALGA rapport beschikbaar. De paraffineblokjes met het tumorweefsel van deze 819 patiënten waren opgeslagen in 54 pathologie laboratoria verspreid door heel Nederland. Na toestemming door de betrokken medischethische commissies, PALGA, de pathologen en de NKR was het weefsel voor deze studie beschikbaar. In totaal kon voor 775 van de 819 patiènten (95\%) het tumormateriaal worden teruggevonden. Voor 737 van hen (95\% van de beschikbare weefselblokjes) kon de $K$-ras mutatie status van exon 1 (waarin codons 12 en 13 zijn gelocaliseerd) worden bepaald.

In hoofdstuk 1 wordt een literatuuroverzicht gegeven van de relaties tussen voeding en dikke darmkanker, en van de (genetische) ontwikkeling van dikke darmkanker met daarbij speciale aandacht voor het $K$-ras gen. Alhoewel veel onderzoek is verricht naar voeding en dikke darmkanker, zijn er maar weinig studies geweest naar de relatie tussen voeding en $K$ ras mutaties.

In hoofdstuk 2 is de frequentie van K-ras mutaties in tumoren van de incidente dikke darmkanker patiënten uit de NLCS beschreven. Tevens werd de mutatiedetectie-techniek, namelijk het op directe wijze bepalen van de basenvolgorde van geamplificeerde en gezuiverde K-ras genfragmenten, op verschillende manieren gevalideerd. De detectielimiet 
werd bepaald op 5\% gemuteerd DNA. Er werd een goede correlatie gevonden tussen de bepaling van $K$-ras mutaties in gevroren tumorweefsel en in gefixeerd, paraffine-ingebed tumorweefsel. Tevens konden de $K$-ras gen mutaties die beschreven zijn in cellijnen afkomstig van dikke darmkanker met onze techniek worden bevestigd. Uiteindelijk werd bij $37 \%$ van de 737 patiënten een mutatie in het $K$-ras gen gevonden. De meest voorkomende types puntmutaties zijn $\mathrm{G}>\mathrm{A}$ transities, en $\mathrm{G}>\mathrm{T}$ en $\mathrm{G}>\mathrm{C}$ transversies, waarbij $\mathrm{G}>\mathrm{T}$ transversies voornamelijk in codon 12 werden gedetecteerd. Tevens werden $G>T$ transversies vooral in rectum tumoren bij vrouwen gevonden. Er werden geen significante verschillen aangetoond voor Dukes' stadiëring of tumordifferentiatie tussen tumoren met of zonder specifieke $K$-ras mutaties.

Vervolgens werd onderzocht of bepaalde voedingsfactoren geassocieerd zijn met het risico op colon of rectum tumoren met of zonder een K-ras mutatie. De keuze van de bestudeerde voedingsfactoren in dit proefschrift is gebaseerd op de kennis van de biologische mechanismen die ten grondslag liggen aan deze $K$-ras mutaties. De resultaten in hoofdstukken 3 tot en met 5 zijn apart gepresenteerd voor colon en rectum kanker aangezien gerapporteerd is dat er verschillen bestaan tussen $K$-ras mutatiepatronen in de diverse sublokalisaties van de dikke darm, en dat colon- en rectumkanker mogelijk een verschillende etiologie hebben. Patiënten met een rectosigmoïd tumor werden uitgesloten voor verdere analyses, omdat 1) het classificeren van een tumor in het rectosigmoïd niet gebeurt volgens een duidelijk criterium en 2) het aantal patiënten met een rectosigmoïd tumor te klein was om adequate analyses te kunnen uitvoeren.

Er zijn vele studies die erop wijzen dat hoge concentraties van heterocyclische aromatische amines, die ontstaan als vlees op zeer hoge temperatuur wordt verhit, en van polycyclische aromatische amines, die gevormd worden door vlees te grillen of te roken, K-ras puntmutaties kunnen veroorzaken. In hoofdstuk 3 worden associaties tussen de inname van (verschillende soorten) vlees, vleeswaren en vis en het risico op colon- of rectumtumoren met of zonder een $K$-ras mutatie beschreven. Een hoge consumptie van rundvlees en vleeswaren bleek significant geassocieerd te zijn met een verhoogd risico op tumoren met een wild type K-ras gen in het colon, maar niet in het rectum. Een hoge consumptie van varkensvlees was geassocieerd met een verlaagd risico op tumoren met een wild type $K$-ras gen in zowel het colon als het rectum. Op basis van de resultaten van deze studie werd geconcludeerd dat een hoge inname van (verschillende soorten) vlees en vleeswaren relevant kan zijn voor de etiologie van colon- en rectumkanker.

Een hoge inname van vetten lijkt ook een rol te spelen bij het ontstaan van colon- en rectumkanker. Uit experimentele studies blijkt dat peroxidatie van $\omega-6$ poly-onverzadigd vet, dat via de voeding wordt opgenomen, leidt tot vorming van malonaldehyde en 4-hydroxynonenal. In dierexperimenteel onderzoek is aangetoond dat deze producten leiden tot DNAadducten aan guanine basen, welke uiteindelijk worden omgezet in $\mathrm{G}>\mathrm{A}$ transities en $\mathrm{G}>\mathrm{T}$ transversies. Is een hoge inname van $\omega-6$ poly-onverzadigd vet geassocieerd met een verhoogd risico op $\mathrm{G}>\mathrm{A}$ transities dan wel $\mathrm{G}>\mathrm{T}$ transversies in het $K$-ras gen in patiënten met colon of rectum kanker? Deze vraag komt aan de orde in hoofdstuk 4. Er zijn geen significante associaties gevonden tussen de inname van totaal vet, verzadigd vet en monoonverzadigd vet enerzijds en het risico op colon en rectum kanker anderzijds, ook niet nadat rekening is gehouden met de $K$-ras mutatiestatus. Een hoge inname van poly-onverzadigd vet (de totale inname van $\omega-3$ en $\omega-6$ poly-onverzadigde vetzuren) en meer specifiek van linolzuur (een hoofdbron van $\omega-6$ poly-onverzadigd vet) zijn wel geassocieerd met een verhoogd risico op colontumoren met een $K$-ras mutatie en deze associatie blijkt onafhankelijk van het type mutatie in de tumor. Voor rectumkanker werden deze relaties echter niet gevonden. Dus, een hoge inname van poly-onverzadigd vet blijkt relevant voor de ontstaanswijze van colon tumoren met een $K$-ras mutatie. 
Foliumzuur speelt een belangrijke rol in het koolstofmetabolisme, in de synthese van DNA en in de methylering van DNA en eiwitten. Te weinig inname van foliumzuur kan leiden tot instabiliteit van het genoom; breuken in DNA-ketens kunnen ontstaan doordat thymine onvoldoende voor de DNA-synthese beschikbaar is en doordat er een verhoogde inbouw van uracil plaatsvindt. Tevens kan globale hypomethylering van het hele genoom en regionale hypermethylering in de promotorregio's van genen optreden door een deficiënte foliumzuurinname. In hoofdstuk 5 wordt de relatie tussen foliumzuurinname en $K$-ras mutaties in patiënten met colon- of rectum kanker beschreven. In deze studie werden verschillen gevonden voor mannen en vrouwen. Een hoge foliumzuurinname blijkt geassocieerd te zijn met een verlaagd risico op rectumtumoren bij mannen, ongeacht de $K$-ras mutatiestatus. Echter, bij vrouwen werd een verhoogd risico op rectumtumoren gevonden. Dit verhoogd risico werd gevonden voor tumoren met $K$-ras mutaties, maar ook voor tumoren met een wild type $K$-ras gen. Interessant is dat een hoge inname van foliumzuur bij vrouwelijke patiēnten met een $K$-ras gemuteerde tumor een sterk beschermend effect blijkt te hebben voor $\mathrm{G}>\mathrm{A}$ transities. Foliumzuur lijkt een duidelijke rol te spelen in de ontwikkeling van rectumkanker, en het $K$-res gen lijkt hierbij betrokken te zijn. Deze studie toont ook aan dat in toekomstig moleculair epidemiologisch onderzoek naar foliumzuur de man-vrouw verschillen moeten worden meegenomen.

In hoofdstuk 6 wordt een slotbeschouwing gegeven waarin de belangrijkste bevindingen van onze studie worden samengevat en vergeleken met andere moleculair epidemiologische studies. De resultaten suggereren dat een hoge inname van vlees en vet en een lage inname van foliumzuur van minder groot belang zijn op het risico van die colon of rectum tumoren met puntmutaties in het $K$-ras gen dan was verondersteld. Echter, deze factoren kunnen van etiologisch belang zijn voor het risico op colon of rectum tumoren met een wild type $K$-ras gen. Tevens worden de mogelijkheden en beperkingen van moleculair epidemiologische studies besproken. Ook wordt in dit hoofdstuk aangegeven welke andere genetische factoren in toekomstig moleculair epidemiologisch onderzoek kunnen worden bestudeerd. Deze studie laat zien dat het inbouwen van moleculaire eindpunten in de klassieke epidemiologische onderzoeken naar voeding en kanker een relevante aanpak is om de etiologie van colon- en rectumkanker gedeeltelijk op te helderen. 


\section{Dankwoord en Curriculum Vitae}


Een multidisciplinair project als dit doe je NOOIT alleen.....anders zou het niet multidisciplinair zijn.... Onmogelijk kan ik iedereen noemen, maar mocht iemand zichzelf niet terugvinden....alsnog bedankt!

Allereerst wil ik mijn beide co-promotoren, Matty Weijenberg en Ton de Goeij, en promotor, Piet van den Brandt, bedanken voor hun sturing en steun. Matty, ook al was ik 'jouw eerste AIO' moet ik zeggen dat ik het nooit heb kunnen merken. Jouw niet-aflatende enthousiasme en kritische blik heb ik als zeer motiverend ervaren! Ook mocht ik altijd bij jou binnenvallen, hoe 'klein' het punt ook was...jij kwam zelfs wel eens met drie kinderen mijn kamer binnenvallen als de nood weer eens aan de vrouw was! Matty, ik heb ontzettend veel van je geleerd! Hopelijk heb je wel jouw no-worries-mood tijdens mijn verdediging meegenomen... Ton, onze omgang heb ik altijd als plezierig en leerzaam ervaren (vooral wat betreft mijn engels schrijven waarin ik nogal eens eigenwijs was...). Jij liet altijd alles uit handen vallen als ik met een vraag bij je kwam... en je nam uitgebreid de tijd om mijn vragen te beantwoorden. Naast onderzoekszaken heb ik ook altijd ontzettend genoten van jouw (reis)verhalen. Piet, jou wil ik in eerste instantie bedanken voor het aannemen van deze nuchterling ut 't Noord'n. Tevens wil ik je bedanken voor het (mede) bewaken van mijn voortgang, voor het beoordelen en het leveren van opbouwende kritieken op mijn stukken waardoor deze 'tijdschrift-klaar' werden gestoomd.

De meer dan 120.000 participanten die deelnemen aan de Nederlandse Cohort Studie naar voeding en kanker (NLCS) verdienen een grote dank, evenals alle Pathologieafdelingen in Nederland voor het beschikbaar stellen van het weefselmateriaall Zonder jullie was dit project niet mogelijk geweest.

$s$ C CREAM, get on top... $s \rho$ ! Naast een hit van Prince ook de naam van onze projectgroep! Guido, jij hebt met heel veel enthousiasme orde en structuur weten te scheppen in de 'chaos' van paraffineblokjes, coupes, epjes en pipetpuntjes! Daarnaast stond je altijd open voor een goede discussie dan wel een privé-gesprek. Tot slot heb ik erg veel bewondering gekregen voor jouw pogingen om salsa te leren dansen. Marjolein, halverwege CREAM kwam jij ons versterken. Mede dankzij jouw enorme inzet is het gelukt om de $K$-ras bepalingen tot een goed einde te brengen. Manon, jouw enthousiasme überhaupt en voor het onderzoek is niet te evenaren (Jack bewonder ik des te meer als het hem weer eens gelukt is om jou mee te slepen naar één of ander fantastisch vakantieoord). Adriaan, in de vorm van 'onze afspraakjes' heb jij alle coupes beoordeeld. Dank je well Margreet, na een jaar kwam jij me 'versterken' als mede-AIO op een gelijksoortig project. Naast de discussies op het moleculair epidemiologisch vlak, ben ik veel te weten gekomen over uitgaansgelegenheden inclusief drankjes en de mannen, en reizen. Nog eventjes en dan mag jij! Jan Willem Arends wil ik bedanken voor zijn betrokkenheid in de beginfase van dit project.

Om de NLCS draaiende te houden, is/wordt veel energie en tijd gevraagd van de volgende mensen: Linda van den Bosch, Henny Brants, Sacha van den Crommert, Willy van Dijk, Margje Jansen, Arnold Kester, Ton van Moergastel, Marijke Moll, Harry van Montfort, Jolanda Nelissen, Annemie Pisters, Ruud Schmeitz, Laura Voorrips en Conny de Zwart. Dank jullie wel! Tevens wil ik Sandra Bausch bedanken voor haar kritische en leerzame bijdrage aan mijn artikelen.

Alle collega's van de cap.groep Epidemiologie van de Universiteit Maastricht wil ik bedanken voor de prettige sfeer. Een aantal mensen wil ik speciaal noemen... Caatje, ik had me geen betere kamergenote kunnen wensen! Jij was het Brabantse absorberende vermogen als ik weer eens een frustratie te verwerken had....Gerard "papa" Swaen, ook al hebben we een haat-liefde verhouding, ik heb altijd van onze gesprekken, wandelingen en gesprekken tijdens onze wandelingen genoten. Leo, jou wil ik bedanken voor het overnemen van een periode Mirian-begeleiding en jouw onverdeelde interesse! Boukje, ik 
vond het leuk jou een beetje wegwijs (het grootste deel komt toch echt uit jezelf) te maken in het verzamelen van alle blokjes. Anouk, Christel, Danielle, Marcus, Nicole, Raymond, Rik, Rikkert, Saskia en Öte...mede (ex) promovendi...de meesten zijn mij al voorgegaan. Thamar, zal het ooit goed komen tussen ons? Kim en Femke, 'mijn' stagiaires...jullie voorwerk heeft mede geleid tot een aantal artikelen in dit proefschrift. Cobie, als mede vroege vogel zetten we samen koffie. Dit was mijn wek-service! Nathalie, you did it, girl! Het boekie is prachtig gelay-out, dank je wel. En eeehhh...als ik nog eens van die gigantische tabellen heb, mag ik je dan bellen?

Annelies, Dianne, Jeanet, Mariëlle, Margreet en Marij, mijn KNAW-collegae, wil ik bedanken voor hun interesse en begrip in mijn afronding van mijn promotie. De verkenningscommissie wil ik hierbij ook noemen!

Werktijden zijn van maandag tot en met vrijdag, 's ochtends vroeg tot 's avonds laat! De avonduren en weekenden zijn er om te "ontstressen"....

Bianca (ligt het vliegveld van Parijs nog steeds in het centrum van Parijs?), Ischa (in totale schuld de onschuld zelve...), Judith (mijn "nep"zus) en Natasja ("....oo.....leujkh")... super dat jullie mij altijd het gevoel hebben gegeven dat ik alles bij jullie mocht droppen, zowel letterlijk als figuurlijk! Judith, leuk dat je mijn paranimf wil zijn!

Ellen (mijn andere paranimfl) en Hans, dat een avondje oppassen heeft geleid tot 15 jaar vriendschap! Zullen we er nog minstens 15 bij doen? Harry, Ria, Lian en Heart, dank jullie wel voor jullie gezelligheid. Richard, als mede-noordeling wist jij als geen ander om zaken op de juiste momenten te relativeren. Margriet en Jorge, ik ga eindelijk mee naar Cuba... zucht.....Fleur, Sarah en Marco, ik ben blij dat we elkaar altijd weer opzoeken! Annebe, een positieve instelling is zo belangrijk in het leven, dank je wel dat je me dat laat zien!

Dansen (salsa) is een geweldige uitlaatklep, maar alleen als je 'uitgelaten' kan worden...Marcel, Maurice (en zo ziet zo'n "scriptie" er dus uit...), Harold, Chris, Emiel ("prins op het witte paard"), Ginny, Amel, Carine en Ischa (alweer...), ik mis jullie ontzettend!! Ludovic, Edwin en Helen, dank jullie wel voor alle klimuurtjes en gezelligheid. Gaan we nog eens buiten klimmen?

Leo, Mieke, Rinse, Marga, Imke en Erik...Vać (Hongarije), Hoensbroek, Maastricht, Nijmegen, Heerenveen...zo komen we nog eens ergens! En altijd met veel gezelligheid! Miek, dank voor het vormgeven van de prachtige omslag.

MIJURODIJA...mijn thuishaven! Lieve pap en mam, de basis voor het boekje dat hier ligt, hebben jullie mij gegeven. Jullie zijn onmisbaar! Judith (mijn echte zus), Tony, Roland en Ingrid, jullie maken MIJURODIJA compleet!

Joris, jou zing ik toe... $\mathrm{s}$ Moppie, moppie, moppie, ik vind jou helemaal toppie! $\mathrm{A}$

Bailamos deze vrijdagavond, 19 november 2004! 
Mirian Brink werd op 3 oktober 1973 geboren te Gieten (Drenthe). In 1990 behaalde ze het M.A.V.O diploma aan 'de Esakker' te Gieten. Vervolgens behaalde ze in 1992 het H.A.V.O. diploma aan het D.A.G. Hammarskjöld college/Dr. Nassau college te Assen. In datzelfde jaar begon ze met de studie 'Voeding \& Diêtetiek' aan de HanzeHogeschool te Groningen waarvoor ze het propedeusecertificaat verkreeg. Hiermee werd ze in 1993 toegelaten tot de studie Biologie aan de Rijksuniversiteit Groningen, waar ze in 1998 afstudeerde in de medisch-biologische richting. Tijdens deze studie heeft ze onderzoekservaring opgedaan bij de vakgroepen Biologische Psychiatrie en Pathologie van het Groningen Universitair Medisch Centrum. Na het afstuderen trad zij als assistent in opleiding in dienst bij de afdelingen Epidemiologie en Pathologie van de Universiteit Maastricht. Gedurende deze periode werd het door het Koningin Wilhelmina Fonds (KWF) Kankerbestrijding gesubsidieerde en in dit proefschrift beschreven onderzoek uitgevoerd onder begeleiding van Prof. dr. ir. Piet A. van den Brandt (Epidemiologie), Dr. ir. Matty P. Weijenberg (Epidemiologie) en Dr. Anton F.P.M. de Goeij (Pathologie). Naast werkzaamheden als het analyseren, schrijven en publiceren van gegevens, heeft ze veel energie en tijd gestoken in het coördineren en uitvoeren van het verzamelen van het tumormateriaal uit verschillende laboratoria in Nederland en (deels) het coördineren van de $K$-ras mutatiestatus-bepaling van het patièntenmateriaal (het opzetten van de gebruikte technieken en het verrichten van deze bepalingen is gedaan door twee analisten). Ook heeft ze een coördinerende bijdrage geleverd in de opzet van twee databases waarin gegevens over de voorraad van het tumormateriaal en de $K$-ras mutatiestatus van dikke darmkanker patiënten werden opgeslagen. In deze periode behaalde zij haar registratie voor Epidemiologie-A. Sinds januari 2004 is ze werkzaam bij de Koninklijke Nederlandse Akademie van Wetenschappen (KNAW) in Amsterdam als secretaris van de wetenschapsverkenning 'Multifactoriële aandoeningen in het Genomics-tijdperk' onder begeleiding van Dr. Marij Stukart en uitgevoerd door een verkenningscommissie onder voorzitterschap van Prof. dr. Dirkje S. Postma. 

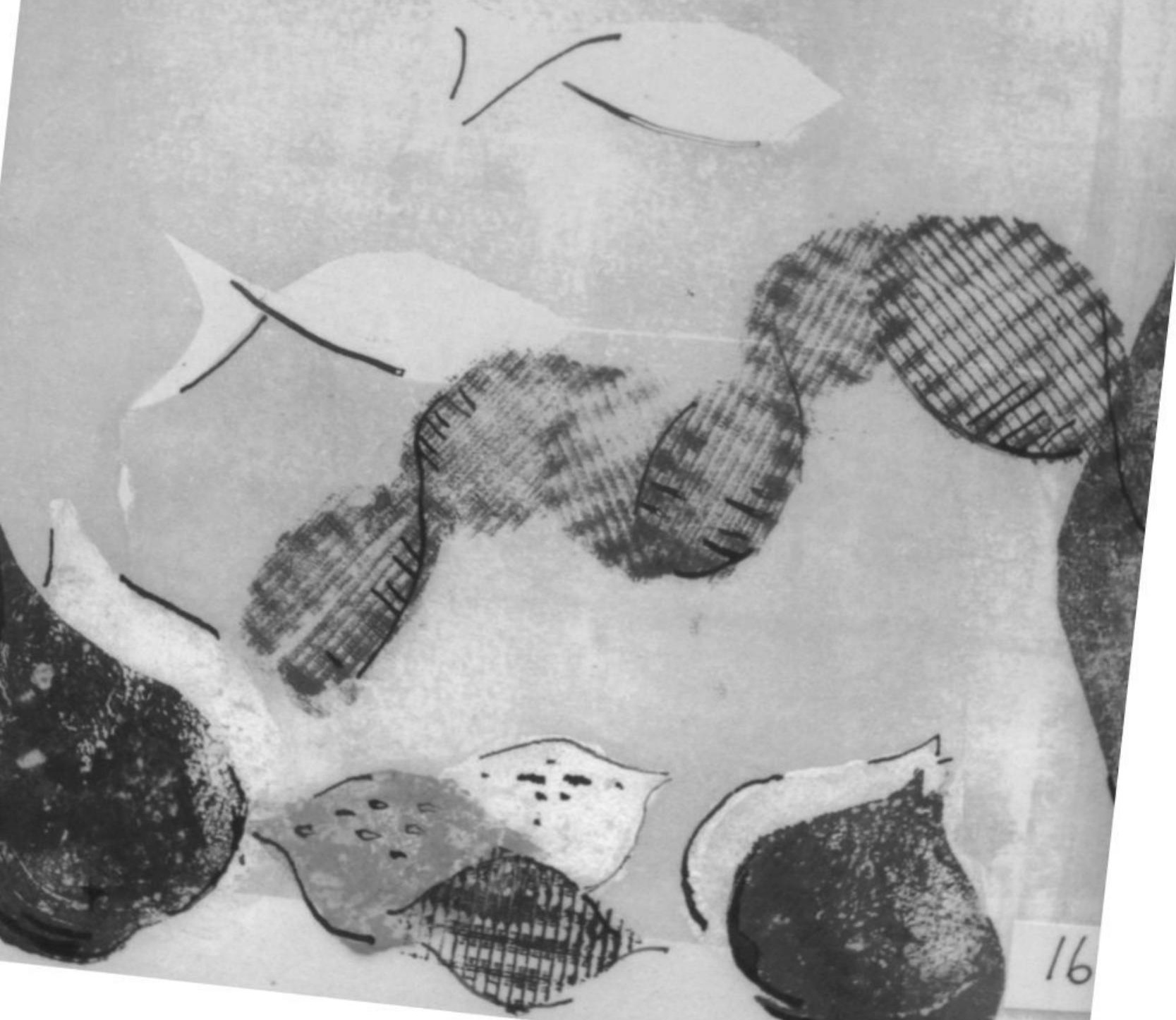